\title{
Comparison of two electrofishing gears (backpack and parallel wires) and abundances of fishes of the upper Greenbrier River drainage
}

Angela D. Burns

West Virginia University

Follow this and additional works at: https://researchrepository.wvu.edu/etd

\section{Recommended Citation}

Burns, Angela D., "Comparison of two electrofishing gears (backpack and parallel wires) and abundances of fishes of the upper Greenbrier River drainage" (2007). Graduate Theses, Dissertations, and Problem Reports. 2516.

https://researchrepository.wvu.edu/etd/2516

This Thesis is protected by copyright and/or related rights. It has been brought to you by the The Research Repository @ WVU with permission from the rights-holder(s). You are free to use this Thesis in any way that is permitted by the copyright and related rights legislation that applies to your use. For other uses you must obtain permission from the rights-holder(s) directly, unless additional rights are indicated by a Creative Commons license in the record and/ or on the work itself. This Thesis has been accepted for inclusion in WVU Graduate Theses, Dissertations, and Problem Reports collection by an authorized administrator of The Research Repository @ WVU. For more information, please contact researchrepository@mail.wvu.edu. 
Comparison of two electrofishing gears (backpack and parallel wires) and abundances of fishes of the upper Greenbrier River drainage

Angela D. Burns

Thesis submitted to the Davis College of Agriculture, Forestry, and Consumer Sciences at West Virginia University in partial fulfillment of the requirements for the degree of

Master of Science

in

Wildlife and Fisheries Resources

Stuart A. Welsh, Ph.D., Chair

J. Todd Petty, Ph. D.

Dan Cincotta, M.S.

Division of Forestry and Natural Resources

Morgantown, West Virginia

2007

Keywords: alternating current, Appalachia darter, backpack, candy darter, electrofishing, Greenbrier River, Kanawha minnow,

New River shiner, parallel wires, sensitive fishes 


\section{ABSTRACT \\ Comparison of two electrofishing gears (backpack and parallel wires) and abundances of fishes of the upper Greenbrier River drainage}

Angela D. Burns

The type of electrofishing gear influences capture efficiencies and abundance estimates of stream fishes. Few studies have examined the Holton and Sullivan (1954) parallel wires method of electrofishing. For this study, I modeled removal data with seven sampling occasions of three common species, western blacknose dace (Rhinichthys obtusus), fantail darter (Etheostoma flabellare), and mottled sculpin (Cottus bairdi) from 10 paired sites in the upper Greenbrier River drainage, West Virginia, and estimated capture efficiencies of two electrofishing gear types (the Holton and Sullivan parallel wires method with alternating current and backpack units with pulsed-direct current). Ten candidate models represented alternative hypotheses of how capture efficiency differs among sites, among stream segments, among gear types, and by site covariates of stream width, water current velocity, water depth, and rock size. Additionally, depending on sample size, I modeled capture probabilities based on four sampling occassions for estimates of abundance or reported total numbers of fish species separated by site and gear type. For each sampling occasion and data for western blacknose dace and fantail darter, capture efficiencies of parallel wires exceeded that of the backpack electrofisher at all sites, and were obtained from the best approximating models of either "gear" or "gear + stream width" effects. For mottled sculpin, capture efficiencies of parallel wires was less than that of the backpack electrofisher at all sites, and were taken from the best approximating models with "gear" or "gear + rock size" effects. First pass estimates of capture probabilities of western blacknose dace and fantail darter were consistently higher for the parallel wires sampling. For mottled sculpin, first pass estimates of capture probabilities were consistently highest from backpack sampling. The parallel wires electrofisher with AC electrical current, through use of electrodes that span the width of the stream, effectively samples pelagic, near-benthic, and some benthic species, but is less effective than DC-pulsed backpack gears at sampling species that use under-rock habitats as refuge. Modification of parallel wires to include DC or pulsed-DC current should improve capture efficiencies of benthic fishes in cobble/boulder streams. 


\section{ACKNOWLEGEMENTS}

I would like to thank my advisor, Dr. Stuart Welsh and committee members Dr. Todd Petty and Dan Cincotta for assistance and advice on this project. Funding was provided by the United States Forest Service and West Virginia Division of Natural Resources. This project would not have been possible without the help of the following individuals: Brandon Keplinger, Dustin Wichterman, Kerry Wixted, Jennifer Lowery, Ken Sheehan, Samantha Warner, Ryan Braham, Cara Hoar, Jamie Detweiler, Dustin Smith, Colin Carpenter, Rebecca Rhodes, Charlie Merceruio, Holly Morris, Jacob Harrell, Alan Shipley, Dave Kayzak, Meram Wentzel, Keith Conrad, Troy Osburne and U.S. Forest Service volunteers. I sincerely thank each individual for their long hours of sampling and support. I would like to thank to the following landowners giving permission to sample on their properties: Marty Clevenger, Tom Melko, and Mr. and Mrs. Herold. I would also like to give a special thanks to Tom Oliver, Mark Cane and Larry and P.J. at the East Fork Campground for providing a home away from home for two summers. I also thank all the fellow students and friends who gave advice, support, and entertainment. I thank my parents, Larry and Karen Burns, for their continued support, pet-sitting services and advice. And finally, to my brother, Joe, for spending a few of his vacation days working on the streams of WV. 
TABLE OF CONTENTS

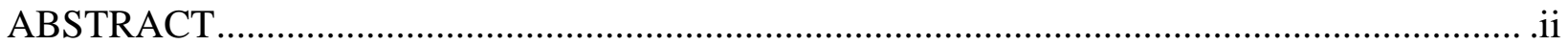

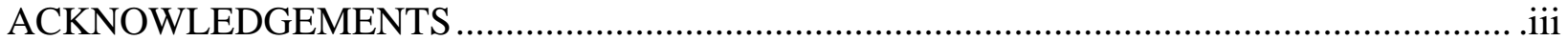

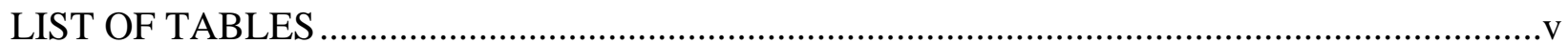

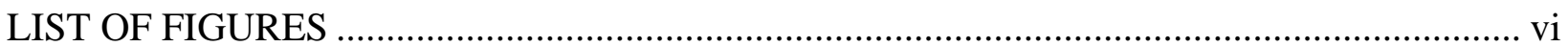

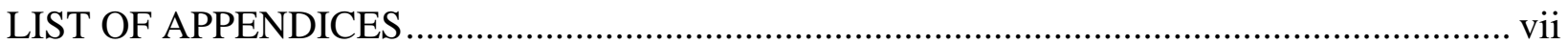

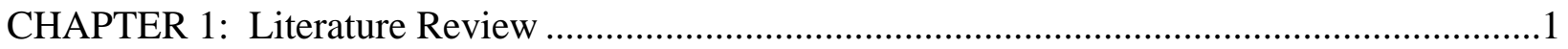

The Monongahela National Forest and the New River basin ........................................1

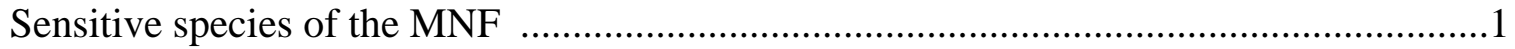

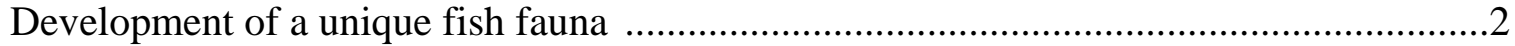

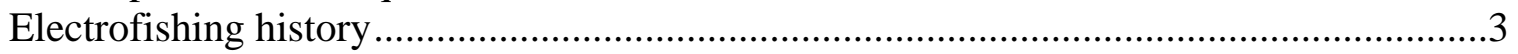

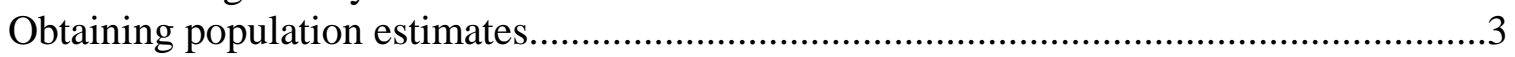

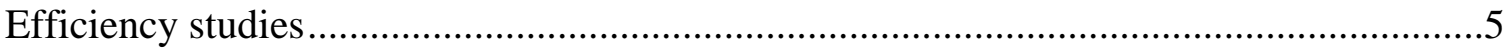

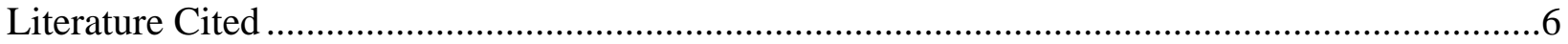

CHAPTER 2: Capture efficiency of the Holton and Sullivan parallel wires electrofishing gear in

first through fourth order streams ...................................................................................12

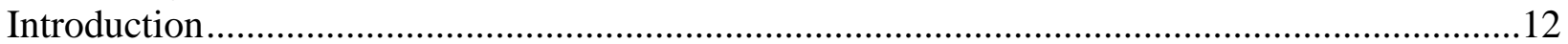

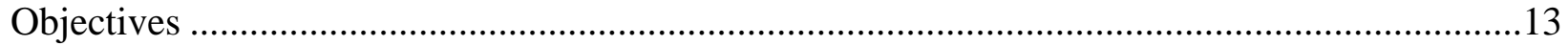

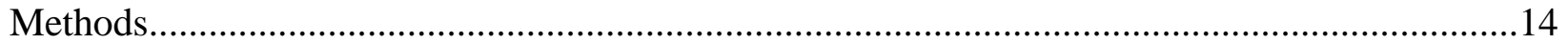

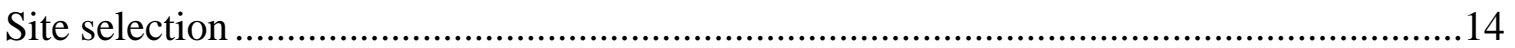

Gear description ............................................................................................... 15

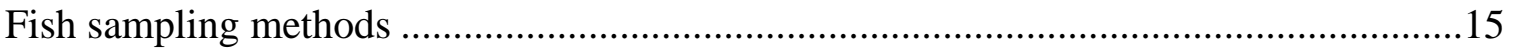

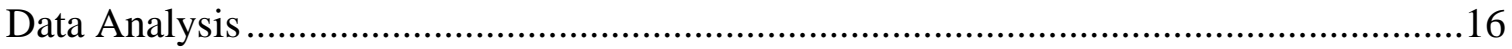

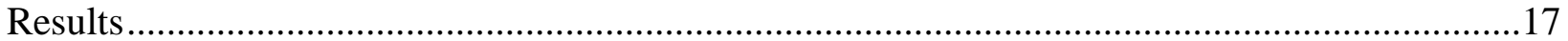

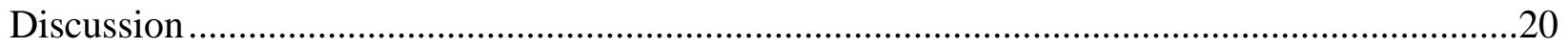

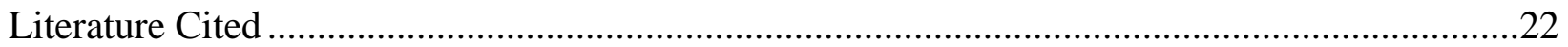




\section{LIST OF TABLES}

Table 1. Location and characteristics of 10 study segments in the upper Greenbrier River watershed, West Virginia. Latitude, longitude and elevation are from the mid-point between compared sections. Strahler's stream orders were calculated on a 1:24,000 USGS Topo map and stream conductivities of the site are given. Averages for habitat variables used as covariates are listed for all sites sampled with backpack (BP) and parallel wires (PW) gears with standard errors (SE)......

Table 2. Candidate capture efficiency models and associated model selection statistics for captures of western blacknose dace with parallel wire and backpack electrofishing gears at 10 paired sites (upper Greenbrier River drainage, WV) for the first (A), cumulative-second (B), and cumulative-third $(\mathrm{C})$ sampling occasions including the number of parameters $(K)$, the second order adjustment of the Akaike information criterion $\left(\mathrm{AIC}_{\mathrm{c}}\right)$, difference in $\mathrm{AIC}_{\mathrm{c}}\left(\Delta_{i}\right)$, and the Akaike weights $\left(w_{i}\right)$ for each model

Table 3: Candidate capture efficiency models and associated model selection statistics for captures of fantail darter with parallel wires and backpack electrofishing gears at 10 paired sites (upper Greenbrier River drainage, WV) for the first (A), cumulative-second (B), and cumulativethird $(\mathrm{C})$ sampling occasions including the number of parameters $(K)$, the second order adjustment of the Akaike information criterion $\left(\mathrm{AIC}_{\mathrm{c}}\right)$, difference in $\mathrm{AIC}_{\mathrm{c}}\left(\Delta_{i}\right)$, and the Akaike weights $\left(w_{i}\right)$ for each model

Table 4: Candidate capture efficiency models and associated model selection statistics for captures of mottled sculpin with parallel wires and backpack electrofishing gears at 10 paired sites (upper Greenbrier River drainage, WV) for the first (A), cumulative-second (B), and cumulative-third $(\mathrm{C})$ sampling occasions including the number of parameters $(K)$, the second order adjustment of the Akaike information criterion $\left(\mathrm{AIC}_{\mathrm{c}}\right)$, difference in $\mathrm{AIC}_{\mathrm{c}}\left(\Delta_{i}\right)$, and the Akaike weights $\left(w_{i}\right)$ for each model

Table 5. Species abundances $(\mathrm{N})$ and capture probabilities (p) estimated from four-pass removal studies with backpack and parallel wire electrofishing gears at 10 paired sites in the upper Greenbrier River drainage, West Virginia. Total counts from seven and four sampling occasions are provided for adults (A) and juveniles (J) of each species. Abundance estimates, standard error (SE), and lower (LCL) and upper (UCL) 95\% confidence limits are provided when fourpass sample sizes exceed 40 individuals. An asterisk adjacent to a four-pass count indicates failure of removal depletion.

Table 6. Mean capture efficiencies for the three commonly captured species with associated standard errors and lower and upper 95\% confidence interval (LCI and UCI)

Table 7. Mean capture probabilities for the three commonly captured species with associated standard errors and lower and upper 95\% confidence interval (LCI and UCI). 


\section{LIST OF FIGURES}

Figure 1. Locations of 10 study reaches (each with two sampling sites) in the upper Greenbrier River drainage, West Virginia, where capture efficiencies and fish abundances were estimated from removal sampling with parallel wire and backpack electrofishing methods

Figure 2. Capture efficiencies of parallel wires (closed) and backpack (open) electrofishers estimated from paired sites within 10 stream segments of the upper Greenbrier River drainage, WV. For each stream segment, estimates for paired sites (adjacent histogram bars) are provided for the first, cumulative-second, and cumulative-third electrofishing sampling occasions...........36 


\section{LIST OF APPENDICES}

Appendix 1. Habitat variables (substrate, velocity, wetted width, and depth) measured across the habitat transects with $95 \%$ confidence intervals on the estimates

Appendix 2. Species abundances (N) and capture probabilities (p) estimated from four-pass removal studies with backpack and parallel wire electrofishing gears at 10 paired sites in the upper Greenbrier River drainage, West Virginia. Total counts from seven and four sampling occasions are provided for adults (A) and juveniles (J) of each species. Abundance estimates, standard error (SE), and lower (LCL) and upper (UCL) 95\% confidence limits are provided when four-pass sample sizes exceed 40 individuals. An asterisk adjacent to a four-pass count indicates failure of removal depletion. Site descriptions given in Appendix 3.1

Appendix 3. Sensitive fish distributions in the Greenbrier River, West Virginia 


\section{CHAPTER 1: Literature Review}

This literature review, in part, focuses on the fish fauna of the New River drainage within the Monongahela National Forest (MNF) and provides literature support for my study of abundance estimates of fish populations within the upper Greenbrier River drainage. I was given two options of fish sampling methods within the upper Greenbrier River system (backpack and parallel wires electrofishers). Several regional biologists suggested parallel wires as a preferred method, but little research was available for this sampling method. Therefore, the second part of this literature review provides background information relative to stream fish sampling with electrofishers, and supports my primary thesis focus on capture efficiency of parallel wires electrofishers.

The fish fauna of the $3,719 \mathrm{~km}^{2}$ MNF occurs primarily within the headwaters of six major river systems (Monongahela, Potomac, Greenbrier, Elk, Tygart, and Gauley, USDA 2006), and includes seven "sensitive" fish species. Sensitive species are identified by the regional forester based on concerns of population viability. Concerns are based on evidence of current and predicted downward trends in population numbers, density, or habitat capability which could reduce the distributions of these species (Lawrence Livermore National Laboratory 2005). Seven species have "sensitive" status within MNF; New River shiner (Notropis scabriceps), Kanawha minnow (Phenacobius teretulus), candy darter (Etheostoma osburni), redside dace (Clinostomus elongatus), pearl dace (Margariscus margarita), Cheat minnow (Pararhinichthys bowersi) and Appalachia darter (Percina gymnocephala). The Greenbrier and Gauley rivers occur in the southern MNF, and have populations of four "sensitive" New River endemics (New River shiner, Kanawha minnow, candy darter, and Appalachia darter, USDA 2006) with historic and recent collections in the Greenbrier and Gauley River basins (Addair 1944, Hocutt et al. 1978, Chipps et al. 1993, Sporre 1996, Cincotta et al. 1999, Messinger and Chambers 2001). 
The fish fauna of the New River basin is partly a product of both drainage evolution and recent fish introductions (Wellman 2004). Jenkins and Burkhead (1994) listed 8 of 46 native fish species as endemic to the New River basin. The proportion of endemic species to native species in the New River, as well as the number of non-native fishes are among the highest within drainages of the eastern United States (Cincotta et al. 1999). The New River basin was the headwaters of the historic Teays River system, which was probably a major route of fish dispersal from the east-central United States to the ancestral Mississippi (Steeg 1946, Hocutt et al. 1978, Jenkins and Burkhead 1994). Glaciations and deglaciations altered the lower Teays drainage, and headwater streams possibly served as refuge areas (Hocutt et al. 1978). Fish dispersal toward New River headwaters was likely limited by Kanawha Falls, a 7.3 m waterfall dividing the upper Kanawha (New) river system from the lower Kanawha. Kanawha Falls, along with three other upstream cataracts (Wylie Falls, Bull Falls, and Sandstone Falls), may have hindered upstream fish dispersal within the New River (Cincotta et al. 1999, Messinger and Chambers 2001), and is often used to explain the low overall fish diversity and high endemic fish diversity of the New River drainage (Hocutt and Wiley 1986, Hocutt et al. 1978, 1979).

The persistence of sensitive endemics depends on a number of physical, biological and chemical factors. Poor management practices on private and public lands concern managers of the MNF, and include increased sedimentation, increased stream temperatures, decrease habitat conditions and channel stability, and fragmentation of habitat (USDA 2006). Additionally, biological threats of introduced species within the New River system are not well understood (Messinger and Chambers 2001). Hybridization has occurred between congeneric pairs of native and non-native species, such as the Appalachia darter and Roanoke darter (Percina roanoka, Hocutt and Hambrick 1973) and variegate darter (Etheostoma variatum) and candy darter (Switzer et al. 2007). However, in addition to a need for studies of native/non-native 
species interactions, managers of the MNF need current data on the distribution and abundances of "sensitive" fishes.

Electricity has been used widely over nearly 50 years in population estimate studies and is generally considered the most efficient method available of live capture of fishes (Funk 1958, Wiley and Tsai 1983, Angermeier et al. 1991). The use of electricity as a fisheries tool was pioneered by Burr (1931) as a means of controlling fish populations. Haskell (1940) created an electrofishing apparatus that worked in streams under 20 feet in width and 3 feet in depth. After the publications of Haskell (1940) and Haskell and Zilliox (1941) the use of electro-shocking as a means to study stream fish populations spread rapidly (Schuck 1945, Funk 1949). Several forms of AC- electric "seines" developed. Funk (1949) designed a seine for wider sites by equipping the unit with a series of floating electrodes. Modifications were made by Larimore (1961) to include fifteen inch drop electrodes from the surface cable. In West Virginia, methods were modified to create a parallel wires unit. These wires were of opposite polarity and extended across the entire stream. This method created a more uniform current; however, it was more difficult to maneuver around bottom structures than single drop line models (Holton and Sullivan 1954). Commercialized DC backpack units have gained widespread popularity in recent years. These units are light, safe, portable, and can be used with smaller crews in comparison to many of the AC gears (Oronato et al. 1998, Young and Schmetterling 2004, Bertrand et al. 2006).

Estimation of population size of stream fishes often involves electrofishing sampling methods within mark-recapture or removal study designs (Seber and LeCren 1967, Wiley and Tsai 1983). Though mark-recapture studies are theoretically superior, removal studies are more suited for estimating fish populations in small rivers where fish are small, habitats diverse, and the fish population is heterogeneous (Johnson 1965, Seber and LeCren 1967, Wiley and Tsai 1981, Peterson and Cederholm 1984). Removal studies use successive catch data from a closed 
population to estimate capture probabilities and population size. Researchers have examined bias in removal studies with the following three basic approaches (Peterson 2004); stocking known numbers of fish into a site (Rodgers et al. 1992), using dual gear procedure (Bayley et al. 1989, Bayley and Austen 2002), or collecting, marking, and returning fish to a site (Runstrom et al. 2001).

Estimates of abundance and capture probabilities are biased by biological, environmental, and technical factors when obtained from multiple-pass electrofishing removal studies (Zippin 1956, Otis 1978, Temple et al. 1998). Biased estimates of abundance and capture probability are influenced by biological factors of fish size and shape, and species behaviors (Anderson 1995, Onorato et al.1998), physical and chemical environmental factors (Riley and Fausch 1992, Hill and Willis 1994, Kolz 2006) and technical factors such as the experience of the sampling crew (Hardin and Connor 1992), the number of removal passes (Peterson 2004, Meador et al. 2003, Meador 2005), and the statistical estimator (White et al. 1982, Riley and Fausch 1992). Additionally, biased estimates of abundance and capture probability are also influenced by gear type (Vadas and Orth 1993, Weaver et al. 1993, Onorato et al. 1998).

Valid estimates from removal studies require three conditions. First, a population must be closed (i.e., no births, deaths, immigration or emigration). Second, sampling effort is constant for each capture occasion. Finally, the probability of capture remains the same for each capture occasion (Otis et al. 1978, Riley and Fausch 1992). The first two assumptions are met by sound sampling practices. In order to ensure a closed population, sampling takes place over a short time period (Krebs 1999) and block nets are often used for stream sampling. Time on subsequent passes may decline as fewer fish are encountered, but this reflects a reduction in handling time and not a reduction in sampling effort (Riley and Fausch 1992). Constant capture probability is the most difficult assumption to fulfill. Following the first sampling occasion, fishes may become frightened and seek out cover during subsequent passes. Therefore, fishes 
may become less catchable (Riley and Fausch 1992). To lessen this reduced catchability, electrofishing methods that capture more individuals on the first pass are most desirable (Peterson 2004).

Multiple pass electrofishing is used as an attempt to reduce the influence of sampling biases (Zippin 1956, Otis 1978). Although single-pass (one sampling occasion) electrofishing reduces time and labor costs relative to multi-pass sampling (Meador et al. 2003, Bertrand et al. 2006), some researchers have emphasized the need for a least three sampling occasions for modeling and estimation of capture probabilities and for increasing the precision of abundance estimates (White et al. 1982). Removal studies fail if the population size is not reduced by each sampling occasion (White et al. 1982, Pollock 1991, Heimbuch et al. 1997), and the probability of this type of failure increases with an increase in the number of sampling occasions.

The end goal of an abundance study is to have a reliable estimate of the fish population (Bayley and Herendeen 2000). Reliability is influenced by the ability to capture fishes, or the capture efficiency of a method. Capture efficiency studies have been popular (Pratt 1952, Wiley and Tsai 1983, Bayley and Austen 1988, Bayley et al. 1989, Rodgers et al. 1992, Onorato et al. 1998, Walsh et al. 2002). There have been studies comparing electroshocking to various methods such as seines (Wiley and Tsai 1983, Bayley et al. 1989, Rodgers et al. 1992, Onorato et al. 1998), rotenone, explosives (Layher and Maughan 1984) and snorkeling (Rodgers et al. 1992, Roni and Fayram 2000). Studies have compared different types of electrofishing gears (Pratt 1952, Fisher and Brown 1993, Walsh et al. 2002) as well as different techniques with the same equipment (Vadas and Orth 1993, Simonson and Lyons 1995). Studies of this nature can be very helpful selecting the best approach to obtain reliable population estimates.

Previous studies have compared electric seines to pulse-DC backpack electrofishers. Bayley et al. (1989) conducted an electrofishing comparison with a modified Larimore (1961) unit in warm water streams of Illinois where electrofishing trials were followed by rotenone 
treatment. Gear efficiency with the electric seine was higher for centrarchids, percids, silurids, esocids and catostomids. Bayley et al. (1989) recommended electric seines to estimate common fish taxa in most wadeable stream sampling situations. Angermeier et al. (1991) modified this method further, and conducted a study in several headwater streams in western Virginia. In their study they conducted 10 pass electrofishing to come up with relative capture efficiencies. This estimate differed from many previous studies in that the absolute size of the population was not required. They found their ratio and cumulative proportions yielded similar results of those efficiency studies using chemical treatments to find absolute efficiencies. Results from this study showed the modified electric seine to capture a greater proportion of fishes than previous studies of DC electrofishing gears (Angermeier et al. 1991). Studies have not estimated capture efficiency associated with the parallel wires method of Holton and Sullivan (1954) to that of a DC-backpack unit.

This thesis includes data on current distributions of sensitive fishes within the Greenbrier River drainage of the MNF, and focuses on electrofishing sampling methods with an emphasis on parallel wires methodology. Specifically, the second chapter is a manuscript of an electrofishing comparison study between backpack and parallel wire units at ten paired-sites and compares the capture efficiencies of these methods. Appended are additional results relevant to the Chapter 2 manuscript, as well as a summary (including distribution maps and data tables) of an additional three-pass study designed to collect distribution and abundance data for sensitive fish species in the Greenbrier River basin within the MNF boundaries.

\section{Literature Cited}

Addair, J. 1944. The fishes of the Kanawha River System in West Virginia and some factors which influence their distribution. Ph.D. dissertation. The Ohio State University, Columbus, Ohio.

Anderson, C.S. 1995. Measuring and correcting for size selection in electrofishing markrecapture experiments. Transactions of the American Fisheries Society 124:663-676. 
Angermeier, P.L., R.A. Smogor an S.D. Steele. 1991. An electric seine for collecting fish in streams. North American Journal of Fisheries Management 11:352-357.

Bayley, P.B. and D.J. Austen. 1988. Comparison of detonating cord and rotenone for sampling fish in warmwater impoundments. North American Journal of Fisheries Management 8:310-316.

Bayley, P.B. and D.J. Austen. 2002. Capture efficiency of a boat electrofisher. Transactions of the American Fisheries Society 131:435-451.

Bayley, P.B. and R.A. Herendeen. 2000. The efficiency of a seine net. Transactions of the American Fisheries Society 129:901-923.

Bayley, P.B., W. Larimore and C. Dowling. 1989. Electric seine as a fish-sampling gear in streams. Transactions of the American Fisheries Society 118:447-253.

Bertrand, K.N., K.B. Gido and C.S. Guy. 2006. An evaluation of single-pass versus multiplepass backpack electrofishing to estimate trends in species abundance and richness in prairie streams. Transactions of the Kansas Academy of Science 109:131-138.

Burr, J.G. 1931. Electricity as a means of garfish and carp control. Transactions of the American Fisheries Society 61:174-181.

Cincotta D. A., D.B. Chambers and T. Messinger. 1999. Recent changes in the distribution of fish species in the New River basin in West Virginia and Virginia. Proceeding of the New River Symposium p.98-106.

Chipps, S.R., W.B. Perry and S.A. Perry. 1993. Status and distribution of Phenacobius teretulus, Etheostoma osburni, and "Rhinchthys bowersi" in the Monongahela National Forest, West Virginia. Virginia Journal of Science 44:47-58.

Fisher, W.L. and M.E. Brown. 1993. A prepositioned areal electrofishing apparatus for sampling stream habitats. North American Journal of Fisheries Management 13:807-816.

Funk, J.L. 1949. Wider application of the electrical method of collecting fish. Transactions of the American Fisheries Society 77:49-60.

Hardin, S. and L.L. Connor. 1992. Variability of electrofishing crew efficiency, and sampling requirements for estimating reliable catch rates. North American Journal of Fisheries Management 12:612-617.

Haskell, D.C. 1940. An electrical method of collecting fish. Transactions of the American Fisheries Society 69:210-215.

Haskell. D.C. and R.G. Zilliox. 1941. Further development of the electrical method of collecting fish. Transactions of the American 70:404-409.

Heimbuch, D.G., H.T. Wilson, S.B. Weisberg and J.H. Vølstad. 1997. Estimating fish abundance in stream surveys by using double-pass removal sampling. Transactions of the American Fisheries Society 126:795-803. 
Hill, T.D. and D.W. Willis. 1994. Influence of water conductivity on pulsed AC and pulsed DC electrofishing catch rates for largemouth bass. North American Journal of Fisheries Management 14:202-207.

Hocutt, C. H., R. F. Denoncourt and J. R. Stauffer, Jr. 1978. Fishes of the Greenbrier River, West Virginia, with drainage history of the Central Appalachians. Journal of Biogeography 5:59-80.

Hocutt, C. H., R. F. Denoncourt and J. R. Stauffer, Jr. 1979. Fishes of the Gauley River, West Virginia. Brimleyana 1:47-80.

Hocutt, C.H., and P.S. Hambrick. 1973. Hybridization between darters Percina crassa roanoka and Percina oxyrhyncha (Percidae, Etheostomatini), with comments on the distribution of Percina crassa roanoka in New River. The American Midland Naturalist 90: 397-405.

Hocutt, C.H., R.E. Jenkins and J.R. Stauffer. 1986. Zoogeography of the fishes of the central Appalachians and central Atlantic Coastal Plain. Pages 161-211 in Hocutt and Wiley (1986).

Hocutt, C.H. and E.O. Wiley, editors. 1986. The zoogeography of North American freshwater fishes. John Wiley and Sons, New York.

Holton, G. and C. Sullivan, Jr. 1954. West Virginia's electrical fish-collecting methods. Progressive Fish Culturalist 16:10-18.

Jenkins, R. and N. Burkhead. 1994. Freshwater Fishes of Virginia. American Fisheries Society, Bethesda, Maryland.

Johnson, M.G. 1965. Estimates of fish populations in warmwater streams by the removal method. Transactions of the American Fisheries Society 94:351-357.

Kolz, A.L. 2006. Electrical conductivity as applied to electrofishing. Transactions of the American Fisheries Society 135:509-518.

Krebs, C.J. 1999. Ecological Methodology, 2nd edition. Addison-Welsey Educational Publishers, Inc., Menlo Park, California.

Larimore, R.W. 1961. Fish population and electrofishing success in a warm-water stream. The Journal of Wildlife Management 25:1-12.

Layher, W.G. and O.E. Maughan. 1984. Comparison efficiencies of three sampling techniques for estimating fish populations in small streams. Progressive Fish Culturalist 46:180-184.

Lawrence Livermore National Laboratory. 2005. Sensitive and Protected or Special Status Species. Document 33.2 in Environment, Safety and Health manual Vol. III: Environment-Environmental Aspects and Controls. Part 33: Ecological and Cultural Resources. University of California Lawrence Livermore National Laboratory, UCRLAM-133867. 
Meador, M.R. 2005. Single-pass versus two-pass boat electrofishing for characterizing river fish assemblages: species richness estimates and sampling distance. Transactions of the American Fisheries Society 134:59-67.

Meador, M.R., J.P. McIntyre and K.H. Pollock. 2003. Assessing the efficacy of single-pass backpack electrofishing to characterize fish community structure. Transactions of the American Fisheries Society 132:39-46.

Messinger, T. and D.B. Chambers. 2001. Fish communities and their relation to environmental factors in the Kanawha River Basin, West Virginia, Virginia, and North Carolina, 199798. U.S. Geological Water-Resource Investigation Report 01-4048.

Onorato, D.P., R.A. Angus and K.R. Marion. 1998. Comparison of a small-mesh seine and a backpack electroshocker for evaluating fish populations in a north-central Alabama stream. North American Journal of Fisheries Management 18:361-373.

Otis, D.L., K.P. Burnham, G.C. White and D.R. Anderson. 1978. Statistical inference from capture data on closed animal populations. Wildlife Monographs 62: 1-135.

Peterson, J.T. 2004. An evaluation of multipass electrofishing for estimating the abundance of stream-dwelling salmonids. Transactions of the American Fisheries Society 133:462475.

Peterson, N.P. and C.J. Cederholm. 1984. A comparison of the removal and mark-recapture methods of population estimation for juvenile Coho salmon in a small stream. North American Journal of Fisheries Management 4:99-102.

Pollock, K.H. 1991. Modeling capture, recapture, and removal statistics for estimation of demographic parameters for fish and wildlife populations: past, present, and future. Journal of the American Statistical Association 86:225-238.

Pratt, V.S. 1952. A measure of the efficiency of alternating and direct current fish shockers. Transactions of the American Fisheries Society 81:63-68.

Riley, S.C. and K.D. Fausch. 1992. Underestimation of trout population size by maximumlikelihood removal estimates in small streams. North American Journal of Fisheries Management 12:768-776.

Rodgers, J.D., M.F. Solazzi, S.L. Johnson and M.A. Buckman. 1992. Comparison of three techniques to estimate juvenile Coho salmon populations in small streams. North American Journal of Fisheries Management 12:79-86.

Roni, P. and A. Fayram. Estimating winter salmonid abundance in small western Washington streams: a comparison of three techniques. North American Journal of Fisheries Management 20: 683-692.

Runstrom, A.L., B. Vondracek and C.A. Jennings. 2001. Population statistics for paddlefish in the Wisconsin River. Transactions of the American Fisheries Society 130:546-556. 
Schuck, H.A. 1945. Survival, population density, growth, and movement of the wild brown trout in Crystal Creek. Transactions of the American Fisheries Society 73:209-230.

Seber, G.A.F. and E.E. Le Cren. 1967. Estimating population parameters from catches large relative to the population. Journal of Animal Ecology 36:631-643.

Simonson, T.D. and J. Lyons. 1995. Comparison of catch per effort and removal procedures for sampling stream fish assemblages. North American Journal of Fisheries Management $15: 419-427$.

Sporre, T.D. 1996. The status of the Kanawha minnow and habitat of associated ichthyofauna in the Monongahela National Forest, West Virginia. Master's Thesis, West Virginia University, Morgantown, WV.

Steeg, K.V. 1946. The Teays River. The Ohio Journal of Science 66:297-307.

Switzer, J., S. Welsh, and T. King. 2007. A molecular genetic investigation of hybridization between Etheostoma osburni and Etheostoma variatum in the New River drainage. Final report submitted to the National Park Service, Glen Jean, WV, and the West Virginia Division of Natural Resources, Elkins, WV.

Temple, A.J., W.E. Ensign, and R.J. Neves. 1998. Chapter 9: The effects of fright bias on sampling efficiency for stream fish assemblages. Pages 13-28 in Kolz, A.L., J. Reynolds, A. Temple, J. Boardman, and D. Lam, editors. Principles and Techniques of Electrofishing, U.S. Fish and Wildlife Service, National Conservation Training Center, Branch of Aquatic Resources Training, Shepherdstown, WV.

United States Department of Agriculture. 2006. Monongahela National Forest: Final environmental impact statement for forest plan revision. 2006. United States Forest Service.

Vadas, R.L. and D.J. Orth. 1993. A new technique for estimating abundance and habitat use of stream fishes. Journal of Freshwater Ecology 8(4):305-317.

Walsh, M.G. D.B. Fenner and D.L. Winkelman. 2002. Comparison of an electrical seine and prepositioned area electrofishers for sampling stream fish communities. North American Journal of Fisheries Management 22:77-85.

Weaver, M.J., J.J. Magnuson and M.K. Clayton. 1993. Analyses for differentiating littoral fish assemblages with catch data from multiple sampling gears. Transactions of the American Fisheries Society 122:1111-1119.

Wellman, D.I. 2004. Post-flood recovery and distributions of fishes in the New River Gorge National River, West Virginia. Master's Thesis, West Virginia University, Morgantown, WV.

White, G.C., D.R. Anderson, K.P. Burnham and D.L. Otis. 1982. Capture-recapture and removal methods for sampling closed populations. Los Alamos National Laboratory, LA-8787-NERP, Los Alamos, New Mexico. 
Wiley, M.L. and C. Tsai. 1983. The relative efficiencies of electrofishing vs. seines in Piedmont streams of Maryland. North American Journal of Fisheries Management 3:243-253.

Young, M.K. and D.A. Schmetterling. 2004. Electrofishing and salmonid movement: reciprocal effects in two small montane streams. Journal of Fish Biology 64:750-761.

Zippin, C. 1956. An evaluation of the removal method of estimating animal populations. Biometrics 12:163-189. 


\section{CHAPTER 2: Capture efficiency of the Holton and Sullivan parallel wires electrofishing gear in first through fourth order streams}

\section{$\underline{\text { Introduction }}$}

Removal sampling with an electrofisher is a common method for estimation of fish abundance in wadeable streams (Johnson 1965; Seber and LeCren 1967, Wiley and Tsai 1981, Peterson and Cederholm 1984). Several electrofishing gears are available, and studies have compared different gear types (Pratt 1952, Bayley et al. 1989, Angermeier et al. 1991, Walsh et al 2002), as well as different sampling techniques, such as the number of sampling occasions, with the same equipment (Vadas and Orth 1993, Simonson and Lyons 1995). Although singlepass (one sampling occasion) electrofishing reduces time and labor costs relative to multi-pass sampling (Meador et al. 2003, Bertrand et al. 2006), some researchers have emphasized the need for a least three sampling occasions for modeling and estimation of capture probabilities and for increasing the precision of abundance estimates (White et al. 1982, Pollock 1991). Removal studies fail if the population size is not reduced by each sampling occasion (White et al. 1982), and the probability of this type of failure increases with an increase in the number of sampling occasions.

Estimates of abundance and capture probabilities may be biased by biological, environmental, and technical factors when obtained from multiple-pass electrofishing removal studies (Zippin 1956, Otis 1978, Kolz et al. 1998). Biased estimates of abundance and capture probability are not only influenced by biological factors of fish size and shape, and species behaviors (Sullivan 1956, Anderson 1995, Onorato et al.1998), and physical and chemical environmental factors (Riley and Fausch 1992, Hill and Willis 1994, Kolz 2006), but also technical factors such as the experience of the sampling crew (Hardin and Connor 1992), the number of removal passes (Meador et al. 2003, Peterson 2004), and the statistical estimator (White et al. 1982, Riley and Fausch 1992). Additionally, biased estimates of abundance and 
capture probability are also influenced by gear type (Vadas and Orth 1993, Weaver et al. 1993, Onorato et al. 1998).

Electrofishing gear comparisons can be based on sampling efficiency (i.e., the percent of the population captured by sampling, Kolz et al. 1998). The actual population size is generally unknown, so a capture efficiency is often estimated by a ratio of the total number or population estimate from one or multiples passes to an estimated population size. Generally, a high capture efficiency on the first electrofishing pass is preferred, particularly for removal studies where numbers of fish during each pass must be higher than those of subsequent passes (White et al. 1982, Pollock 1991, Heimbuch et al. 1997).

An understanding of gear-influenced biases, such as gear avoidance, is important when designing studies for abundance estimation. Backpack DC electrofishers are commonly used to sample wadeable streams (Oronato et al. 1998, Meador et al. 2003, Bertrand et al. 2006), but other gears are also used, such as Backpack AC units, pre-positioned area shockers (Fisher and Brown 1993, Temple et al. 1998, Walsh et al. 2000), and several modifications of electric seines ranging from electrode arrays with droppers (Bayley et al. 1989, Angermeier et al. 1991, Walsh et al. 2000) to a simple design of two wire electrodes (i.e., parallel wires, Holton and Sullivan 1954). Abundance estimates and associated capture efficiency from backpack DC units are biased, in part, by gear avoidance (Bayley et al. 1989). A parallel-wire electrofisher minimizes this bias because wire electrodes (stretched across the width of the stream) reduce gear avoidance (Holton and Sullivan 1954, Angermeier et al. 1991).

\section{$\underline{\text { Objectives }}$}

Although researchers have compared several types of electrofishing gears (Pratt 1952, Wiley and Tsai 1983, Bayley and Austen 1988, Bayley et al. 1989, Rodgers et al. 1992, Onorato et al. 1998, Walsh et al. 2002), studies have not estimated capture efficiency associated with the parallel wires method of Holton and Sullivan (1954). My objectives were to model and estimate 
capture efficiencies from a paired-site design of removal studies with parallel wires and backpack electrofishers within the upper Greenbrier River drainage, West Virginia. I provide abundance estimates and total numbers of fish species by sites and gear type.

\section{Methods}

Site selection

The study was conducted in the upper Greenbrier River drainage, Monongahela National Forest. During summer and fall 2005, I sampled 10 stream segments (each with paired sites) in the upper Greenbrier River, Pocahontas County, West Virginia: Knapp Creek, Galford Run, West Fork Greenbrier River, Little River of the West Fork Greenbrier River, Little River of the East Fork Greenbrier River, the East Fork Greenbrier River (four sites), and Long Run (Table 1, Figure 1). Elevations of study segments ranged from 831 to $929 \mathrm{~m}$ (estimated at locations between paired sites, Table 1). Water conductivities ranged from 31 to $69 \mu \mathrm{S} / \mathrm{cm}$ (Table 1 ) and primarily reflect the Pocono and Mauch Chunk bedrock geologies of the upper Greenbrier River drainage (Flegel 1999).

The 10 stream segments were selected based on availability of at least two $15 \mathrm{~m}$ or greater sections of riffle/run habitat within $100 \mathrm{~m}$ of each other. This allowed a paired site comparison of the two electrofishing methods within each sampling reach, and reduced variation in water chemistry for between gear comparisons. A habitat assessment at each site was used to compare paired-sites and to provide habitat-based covariates for analysis. For habitat assessment, each site was divided into 5 equidistant transects. Substrate (a modified Wolman pebble count, Bain and Stevenson 1999), stream depth (m), and water current velocity (m/s) were measured at 20 points along each transect (Figure 1). Also, we measured wetted width at each transect. 


\section{Gear description}

Holton and Sullivan (1954) described a parallel wire electrofisher powered by a shorebased generator. We modified this design to include a backpack-mounted generator. Specifically, our system was powered by a Honda ${ }^{\circledR} 1.8$ HP EU1000i generator (120V AC output) and a Staco® variable transformer (model 3PN1020B-XDVM) with 120VAC single phase input, 0-280VAC output, 50/60 Hz, 3.5-1.5A, and digital voltmeter. We used two $2.4 \mathrm{~mm}$ zinc coated steel cable electrodes (i.e., "parallel wires") each stretched between two wooden poles (with on/off switches). Cable lengths were adjusted to span the width of the stream, and ranged from 15 to $25 \mathrm{~m}$. Holton and Sullivan (1954) used 12 gauge copper cable as electrodes, but our steel cable electrodes increased maneuverability and decreased cable kink.

\section{Fish sampling methods}

Within each stream reach, the downstream site was sampled first with a randomlyselected gear type (parallel wire or backpack electrofisher), and the upper site was sampled either the same or following day using the alternative method. At each site, we installed block nets $(6.4$ $\mathrm{mm}$ mesh) at the upper and lower ends, and conducted seven passes with a single electrofishing gear. For both methods, two individuals operated the gear, and fishes were netted by two or three individuals (the same crew sampled each of the paired-sites). We fished the parallel wires between 150 and 225 volts (depending on the level needed to induce narcosis but not tetany in fishes, Dolan and Miranda 2004) and a portable volt meter documented constant voltage across the entire length of cable. The parallel wires were fished approximately $1 \mathrm{~m}$ apart, and moved upstream in $1 \mathrm{~m}$ intervals and two or three people netted fishes. Two Smith-Root ${ }^{\circledR}$ backpack electrofishers (models LR-24 and Model 12B, both with $28 \mathrm{~cm}$ electrode rings) were fished with direct current (pulsed-DC) and at 400 volts for most sites (range 300-500 volts). Backpack units were set to a pulse setting of $60 \mathrm{~Hz}$ with a duty cycle of $5 \mathrm{mSec}$, and were fished within $5 \mathrm{~m}$ of each other and in unison upstream during fish sampling. After each pass, fishes were identified 
to species, categorized by age (adult or juvenile, Jenkins and Burkhead 1994), and counted. Fishes were retained in tubs after capture and released following data collection of the last sampling occasion or preserved in a $10 \%$ formalin solution for laboratory identification.

\section{Data analysis}

Capture efficiencies between parallel wire and backpack methods were estimated from removal data of adults of three relatively common species; Rhinichthys obtusus (western blacknose daces), Etheostoma flabellare (fantail darter), and Cottus bairdi (mottled sculpin). Other species and all juveniles were excluded from analysis of capture efficiency because of small sample sizes. Capture efficiency at each site was modeled and estimated separately for the first, cumulative-second, and cumulative-third sampling occasions (hereafter referred to as the $1^{\text {st }}, 2^{\text {nd }}$, and $3^{\text {rd }}$ sampling occasions). The capture efficiency of the first occasion was defined as the proportion of the number collected on the first pass to the total of the seven sampling occasions. The second and third occasion capture efficiencies were estimated as the proportions of the combined $1^{\text {st }}$ and $2^{\text {nd }}$ occasion and the combined $1^{\text {st }}, 2^{\text {nd }}$, and $3^{\text {rd }}$ occasion to the total of the seven sampling occasions, respectively.

I used generalized linear mixed models (PROC GLIMMIX, SAS 2006) with binomial error distribution, log-link function, and randomized block design (block on paired sites) to estimate capture efficiencies for each species and sampling pass. Ten candidate models represented alternative hypotheses of how capture efficiency differs among sites, among stream segments, among gear types, and by site covariates (mean values) of stream width, water current velocity, water depth, and rock size (Table 1). The global model, a site saturated model, parameterized site-specific capture efficiencies. The fit of the global model and an estimate of overdispersion were assessed with the Pearson's chi-square statistic.

I also calculated maximum likelihood estimates of capture probabilities $(\hat{p})$ and abundance estimates $(\hat{N})$ from removal data of parallel wire and backpack sampling methods 
for the 10 paired-sites (using Program MARK, Cooch and White 2006). Capture probabilities were estimated separately for each species and each site, and second sampling occasion probability $(\hat{c})$ was fixed at 0.0 . Candidate models represented alternative hypotheses and were fit to the four-sampling occasion removal data and arranged in order of fit by the second-order adjustment to Akaike's information criterion $\left(\mathrm{QAIC}_{\mathrm{c}}\right.$ ) (Akaike 1973; Burnham and Anderson 2002). We used the following candidate models: 1) $\hat{p}$ constant among sampling occasions (behavioural model $\mathrm{M}_{\mathrm{b}}$ ); 2) $\hat{p}$ of the first sampling occasion differed from that of the following sampling occasions $\left(\mathrm{M}_{\mathrm{bh}}, \mathrm{k}=2\right)$; and 3) $\hat{p}$ differed among first and second sampling occasions but was constant for the third and fourth sampling occasions $\left(\mathrm{M}_{\mathrm{bh}}, \mathrm{k}=3\right)$ (White et al. 1982).

For both analyses of capture efficiencies (PROC GLIMMIX) and abundance estimates (Program MARK, $\hat{p}$ and $\hat{N}$ ), model selection and support for alternative hypotheses followed an information-theoretic approach based on Kullback-Leibler information theory and the secondorder adjustment of Akaike's information criterion (Burnham and Anderson 2002). When model selection uncertainty occurred (i.e., two or more models had $\triangle \mathrm{AICc}<4$ ), then final parameter estimates and unconditional variances were derived from weighted model-averaged estimates and standard errors (Buckland et al. 1997). Also, for both analysis, I calculated mean capture efficiencies (PROC GLIMMIX) and mean capture probabilities (Program MARK) of the first sampling occasion across all ten sites for the three common species for backpack and parallel wires estimates. Standard errors and 95\% confidence intervals were calculated using the sum of the variances of the independent sites (Mood et al. 1974).

\section{$\underline{\text { Results }}$}

The paired-site design reduced influences of habitat variation on comparisons of parallel wires and backpack electrofishing gears. Wetted widths were similar between paired sites (within stream segments) and differed among stream segments (Table 2). Additionally, pairedsites were similar in water depth, water current velocity, and rock sizes of stream bottom 
substrate (Table 1, Appendix 1). The differences of habitat variables were relatively large among sites, and this variation allowed habitat variables to be modeled as covariates in analyses of capture efficiency (range of mean water depth $0.05-0.19 \mathrm{~m}$, range of mean current velocity $0.09-0.36 \mathrm{~m} / \mathrm{s}$, and range of mean diameter of rock sizes $80-323 \mathrm{~mm}$, Table 1).

Capture efficiency differed among the three study species and between gears, and no overdispersion or lack of fit was detected for global models of the analyses of $1^{\text {st }}, 2^{\text {nd }}$, and $3^{\text {rd }}$ sampling occasions. Capture efficiency of parallel wires exceeded that of the backpack electrofisher for western blacknose dace and fantail darter at all sites, whereas capture efficiency of parallel wires was less than that of the backpack electrofisher for mottled sculpin at all sites (Fig 2). For blacknose dace, capture efficiencies of the $1^{\text {st }}, 2^{\text {nd }}$, and $3^{\text {rd }}$ sampling occasions were each estimated from the additive model of Gear + stream width $($ AICc weight $=1.000$, Table 2$)$ and among-site averages ranged from $0.66-0.85,0.81-0.94$ and $0.90-0.95$ for parallel wires and 0.44-0.70, 0.60-0.86, and 0.82-0.90 for backpack electrofisher (Figure 2). For the fantail darter, capture efficiencies were estimated from the Gear model (AICc weight $=0.999,1^{\text {st }}$ sampling occasion, Table 3$)$ and the additive model of Gear + stream width $\left(\mathrm{AICc}\right.$ weight $=1.000,2^{\text {nd }}$ and $3^{\text {rd }}$ sampling occasions, Table 3). For fantail darter and the three sampling occasions, capture efficiencies range for the $0.44-0.67,0.60-0.84$, and $0.84-0.89$ for parallel wires and $0.40-0.62$, 0.54-0.77, and 0.71-0.85 for backpack electrofisher (Figure 2). Capture efficiencies based on data for mottled sculpin were estimated from the Gear model (AICc weight $=0.884,1^{\text {st }}$ sampling occasion, Table 4), from model-averaging of the Gear and Gear + rock size models for the $2^{\text {nd }}$ sampling occasion (AICc weights $=0.517$ and 0.483 , respectively, Table 4), and from the Gear model for the $3^{\text {rd }}$ sampling occasion $($ AICc weights $=1.000$, Table 4$)$. For mottled sculpin, among-site capture efficiencies during the $1^{\text {st }}, 2^{\text {nd }}$, and $3^{\text {rd }}$ sampling occasions ranged from 0.37 $0.54,0.56-0.76$, and $0.69-0.85$ for parallel wires and $0.42-0.58,0.61-0.80$, and $0.72-0.87$ for backpack electrofisher (Figure 2). 
Cumulative capture efficiencies increase with the number of sampling occasions, but the rate of increase differed among species and between gears. The differences in capture efficiency between gears at paired sites decreased with an increase in the number of sampling occasions. The average differences between paired sites for the $1^{\text {st }}, 2^{\text {nd }}$, and $3^{\text {rd }}$ sampling occasions differed among western blacknose dace $(0.18,0.13$ and 0.06$)$ fantail darter $(0.04,0.06$ and 0.05$)$, and mottled sculpin $(0.05,0.05$ and 0.02). Parallel wires had a higher capture efficiency for western blacknose dace for all sites and all sampling occasions when compared to the backpack electrofisher. Parallel wires also had a higher capture efficiency for fantail darters at all sites and all sampling occasions than the backpack electrofisher. However, these differences in capture efficiency between gears at paired sites were smaller than those of western blacknose dace, and these differences were relatively consistent across the three sampling occasions. Likewise, for mottled sculpin data, the differences in capture efficiency between gears at paired sites were smaller than those of blacknose dace, and these differences were relatively consistent across the three sampling occasions, where the backpack electrofisher had a higher capture efficiency than that of the parallel wires for all sites and all sampling occasions.

\section{Abundance estimates}

Twenty-four species were sampled from 10 paired sites (Appendix 2), and $\hat{p}$ and $\hat{N}$ were estimated for three common species (R. obtusus, E. flabellare, and C. bairdi) when fourpass sample size exceeded 40 and when the depletion criterion was met (Table 5). For sample sizes of $<40$, I reported total counts of individuals because abundances are not estimable with low sample size. First-pass estimates of $\hat{p}$ were highest from the parallel wires sites for 10 of 16 paired-site comparisons. Although parallel wires and backpack electrofishing gears were randomly assigned within paired sites, first pass estimates of $\hat{p}$ for $R$. obtusus and E. flabellare at paired sites were consistently higher for the parallel wires sampling ( 4 of 4 , and 4 of 6 four-pass estimates, respectively). For C. bairdi, $\hat{p}$ estimates between paired-sites were consistently 
highest from backpack sampling ( 4 of 6 four-pass estimates). Estimates of $\hat{p}$ differed from those of capture efficiency because $\hat{p}$ was based on 4 sampling occasions and capture efficiency was base on 7 sampling occasions (Tables 6 and 7). The two estimates would be approximately equal if based on the same number of sampling occasions. However, removal estimation of $\hat{p}$ is often difficult because an increase in sampling occasions increases failure of the depletion criterion. When sample sizes for the three common species were $>40$, removal studies failed (numbers did not decrease with sampling occasion) for 10 of 53 four-pass samples. Relative to gear comparisons for 4 sampling occasions, the failure rate was similar for backpack electrofishers ( 5 of 25 four-pass estimates, 20.0\%) and parallel wires ( 5 of 28 four-pass estimates, 17.9\%). Also, four-pass abundance estimates of R. obtusus, E. flabellare, and C. bairdi from both gear types were biased (underestimated) for 33 of 43 estimates relative to total counts from the seven-pass samples.

\section{$\underline{\text { Discussion }}$}

For this study, differences in capture efficiency between parallel wires and backpack electrofishers were influenced by species (phylogenetic constraints and avoidance behavior) and abiotic factors (stream width and rock size). Between-gear differences were partly attributed to the type of electrical current (AC or pulsed-DC). The anodic taxis of pulsed-DC backpack gear (i.e., forced swimming of fish toward the anode, Reynolds 1995) likely explains the higher capture efficiencies for capture data of $C$. bairdi (a benthic species that often occurs under rocks). The AC parallel-wires gear (without anodic taxis) had higher capture efficiencies than that of the backpack gear for E. flabellare (a benthic species often found between or under rocks) and R. obtusus (a near-benthic or pelagic species). My data supports parallel wires with AC current as an effective gear type for wadeable streams (4-10 m widths) with relatively low conductivities $(35-69 \mu \mathrm{S} / \mathrm{cm})$, but the AC gear is less effective when sampling benthic fishes in cobble/boulder streams. Additionally, removal data from parallel wires sampling provided 
higher $\hat{p}$ estimates than that of the DC-pulsed backpack electrofisher for $R$. obtusus and $E$. flabellare, despite random assignment of the two gears at paired sites.

The removal data for R. obtusus and E. flabellare supported models of gear effect and stream width. For these two species, I have two separate interpretations of the higher capture efficiencies of parallel wire gear. For R. obtusus, the "streaming" and "fountain" behaviors of predator avoidance (Magurran and Pitcher 1987, Helfman et al. 1997) allow individuals to avoid the backpack gear (where avoidance increases with stream width), but the parallel wire electrodes cross the width of the stream and provide a complete barrier at all stream widths. Higher capture efficiencies for cyprinids with AC methods have been reported for electric seines (Larimore 1961, Bayley et al. 1989, Angermeier et al. 1991). Etheostoma flabellare does not "stream" as a predator avoidance response, but relies on benthic cover and cryptic pigmentation, essentially staying in place on the stream bottom. As stream width increases, the side-to-side or meandering sampling with the backpack units do not provide complete coverage of the site, and this reduces capture efficiency. In contrast, the parallel wire unit with electrodes stretched across the width of the stream achieves complete coverage of the site during each sampling occasion.

Within gear types, lower capture efficiencies occurred for the benthic fishes (C. bairdi and E. flabellare). This is supported by other studies, and typically explained by cryptic coloration and sedentary nature (Larimore 1961, Brown and Downhower 1982, Bayley et al. 1989, Angermeier et al. 1991). For among gear types, C. bairdi had an opposite interpretation than that of E. flabellare (as explained above). For this study, the removal data of C. bairdi supported models with a gear effect, but also provided support for an influence of rock size, particularly during the second sampling occasion. For C. bairdi, I interpret the use of under-rock microhabitats as a major influence on the overall lower capture efficiencies and differences in capture efficiencies between gear types. Specifically, capture efficiency was lower at sites with larger rocks. The pulsed-DC current educes strong anodic taxis and causes forced swimming 
toward the anode (Reynolds 1995), and this effect moved individuals of C. bairdi away from rocks and into the sight of netters. During sampling with parallel wires, the forced swimming was not educed by the $\mathrm{AC}$ electrical current, and a proportion of the total number of individuals remained under rocks and were not netted by the sampling crew.

Parallel wires and backpack electrofishing gears were randomly assigned within paired sites, but both first-pass estimates of $\hat{p}$ and the failure rate to meet the depletion criterion differed between gear types and among species at paired sites. Four-pass estimates of $\hat{p}$ of $R$. obtusus and E. flabellare for paired sites were consistently higher at sites of parallel wires sampling, and resulted from higher capture efficiencies of the parallel wire gear. Likewise, the higher capture efficiencies of the C. bairdi from backpack gear is reflected in higher four-pass estimates of $\hat{p}$ from that gear type. Although the removal criterion was not met for several four-pass sampling events, the failure rate was not disproportionate among gear types. Abundance estimates from both gear types, however, were biased low relative to total numbers from the 7pass samples. The bias (underestimates) in removal-estimated abundances has been emphasized by others (Peterson 2004), but does not detract from my findings of differences in sampling gear efficiencies among species and between paired-sites.

In conclusion, characteristics of three common species (use of benthic or pelagic habitat and avoidance behaviors) in combination with stream habitat characteristics (stream width and rock sizes) influenced capture efficiencies of backpack and parallel wires within the upper Greenbrier River drainage. The Holton and Sullivan (1954) parallel wires electrofisher with AC electrical current, through use of electrodes that span the width of the stream, effectively samples pelagic, near-benthic, and some benthic species, but is less effective at sampling species that use under-rock habitats as refuge. For additional research, I suggest further modification of the Holton and Sullivan (1954) parallel wires electrofisher to include DC or pulsed-DC current which should improve capture efficiencies of benthic fishes in cobble/boulder streams. 


\section{Literature Cited}

Akaike, H. 1973. Information theory as an extension of the maximum likelihood principle. Pp. 267-281 in B. N. Petrov and F. Csaksi, editors. 2nd International Symposium on Information Theory. Akademiai Kiado, Budapest, Hungary

Anderson, C.S. 1995. Measuring and correcting for size selection in electrofishing markrecapture experiments. Transactions of the American Fisheries Society 124:663-676.

Angermeier, P.L., R.A. Smogor an S.D. Steele. 1991. An electric seine for collecting fish in streams. North American Journal of Fisheries Management 11:352-357.

Bain, M.B., and N.J. Stevenson. 1999. Aquatic habitat assessment: common methods. American Fisheries Society, Bethesda, Maryland.

Bayley, P.B. and D.J. Austen. 1988. Comparison of detonating cord and rotenone for sampling fish in warmwater impoundments. North American Journal of Fisheries Management 8:310-316.

Bayley, P.B., W. Larimore and C. Dowling. 1989. Electric seine as a fish-sampling gear in streams. Transactions of the American Fisheries Society 118:447-253.

Bertrand, K.N., K.B. Gido and C.S. Guy. 2006. An evaluation of single-pass versus multiplepass backpack electrofishing to estimate trends in species abundance and richness in prairie streams. Transactions of the Kansas Academy of Science 109:131-138.

Brown, L. and J.F. Downhower. 1982. Summer movements of mottled sculpin, Cottus bairdi (Pisces:Cottidae). Copeia 1982(2):450-453.

Buckland, S.T., K.P. Burnham and N.H. Augustin. 1997. Model selection: an integral part of inference. Biometrics 53:603-618.

Burnham, K. and D. Anderson. 2002. Model selection and multimodel inference: a practical information-theoretic approach, Second Edition. Springer, New York.

Cooch, E. and G. White. 2006. Program MARK: "A Gentle Introduction," 5th ed.[Online] Available at www.phidot.org/software/mark/ docs/book/.

Dolan, C.R. and L.E. Miranda. 2004. Injury and mortality of warmwater fishes immobilized by electrofishing. North American Journal of Fisheries Management 24:118-127.

Fisher, W.L. and M.E. Brown. 1993. A prepositioned areal electrofishing apparatus for sampling stream habitats. North American Journal of Fisheries Management 13:807-816.

Flegel, D.G., 1999. Soil survey of Pocahontas County, West Virginia. U.S. Department of Agriculture, Natural Resources Conservation Service, Washington, D.C., p. 249.

Hardin, S. and L.L. Connor. 1992. Variability of electrofishing crew efficiency, and sampling requirements for estimating reliable catch rates. North American Journal of Fisheries Management 12:612-617. 
Heimbuch, D.G., H.T. Wilson, S.B. Weisberg and J.H. Vølstad. 1997. Estimating fish abundance in stream surveys by using double-pass removal sampling. Transactions of the American Fisheries Society 126:795-803.

Helfman, G.S., B.B. Collette, and D.E. Facey. 1997. The diversity of fishes, Blackwell Science, Malden, Massachusetts.

Hill, T.D. and D.W. Willis. 1994. Influence of water conductivity on pulsed AC and pulsed DC electrofishing catch rates for largemouth bass. North American Journal of Fisheries Management 14:202-207.

Holton, G. and C. Sullivan, Jr. 1954. West Virginia's electrical fish-collecting methods. Progressive Fish Culturalist 16:10-18.

Jenkins, R. and N. Burkhead. 1994. Freshwater Fishes of Virginia. American Fisheries Society, Bethesda, Maryland.

Johnson, M.G. 1965. Estimates of fish populations in warmwater streams by the removal method. Transactions of the American Fisheries Society 94:351-357.

Kolz, A.L. 2006. Electrical conductivity as applied to electrofishing. Transactions of the American Fisheries Society 135:509-518.

Kolz, A.L., J. Reynolds, A. Temple, J. Boardman, and D. Lam, editors. 1989. Principles and Techniques of Electrofishing, U.S. Fish and Wildlife Service, National Conservation Training Center, Branch of Aquatic Resources Training, Shepherdstown, WV.

Maguran, A.E. and T.J. Pitcher. 1987. Provenance, shoal size, and the sociobiology of predatorevasion behavior in minnow shoals. Proceedings of the Royal Society of London B 229:439-465.

Meador, M.R. 2005. Single-pass versus two-pass boat electrofishing for characterizing river fish assemblages: species richness estimates and sampling distance. Transactions of the American Fisheries Society 134:59-67.

Meador, M.R., J.P. McIntyre and K.H. Pollock. 2003. Assessing the efficacy of single-pass backpack electrofishing to characterize fish community structure. Transactions of the American Fisheries Society 132:39-46.

Mood, A.M., Graybill, F.A., and Boes, D.C. 1974. Introduction to the theory of statistics, third edition. McGraw-Hill, New York.

Onorato, D.P., R.A. Angus and K.R. Marion. 1998. Comparison of a small-mesh seine and a backpack electroshocker for evaluating fish populations in a north-central Alabama stream. North American Journal of Fisheries Management 18:361-373.

Otis, D.L., K.P. Burnham, G.C. White and D.R. Anderson. 1978. Statistical inference from capture data on closed animal populations. Wildlife Monographs 62: 1-135. 
Peterson, J.T. 2004. An evaluation of multipass electrofishing for estimating the abundance of stream-dwelling Salmonids. Transactions of the American Fisheries Society 133:462475.

Peterson, N.P. and C.J. Cederholm. 1984. A comparison of the removal and mark-recapture methods of population estimation for juvenile Coho salmon in a small stream. North American Journal of Fisheries Management 4:99-102.

Pollock, K.H. 1991. Modeling capture, recapture, and removal statistics for estimation of demographic parameters for fish and wildlife populations: past, present, and future. Journal of the American Statistical Association 86:225-238.

Pratt, V.S. 1952. A measure of the efficiency of alternating and direct current fish shockers. Transactions of the American Fisheries Society 81:63-68.

Reynolds, J. B. 1995. Development and status of electric fishing as a scientific sampling technique. Pages 49-61 in G.T. Sakagawa, editor. Assessment methodologies and management. Proceedings of the World Fisheries Congress, Theme 5. Oxford \& IBH Publishing Co., New Delhi.

Riley, S.C. and K.D. Fausch. 1992. Underestimation of trout population size by maximumlikelihood removal estimates in small streams. North American Journal of Fisheries Management 12:768-776.

Rodgers, J.D., M.F. Solazzi, S.L. Johnson and M.A. Buckman. 1992. Comparison of three techniques to estimate juvenile coho salmon populations in small streams. North American Journal of Fisheries Management 12:79-86.

SAS (Statistical Analysis System). 2006. The GLIMMIX Procedure, June 2006. http://support.sas.com/rnd/app/papers/glimmix.pdf.

Seber, G.A.F. and E.E. Le Cren. 1967. Estimating population parameters from catches large relative to the population. Journal of Animal Ecology 36:631-643.

Simonson, T.D. and J. Lyons. 1995. Comparison of catch per effort and removal procedures for sampling stream fish assemblages. North American Journal of Fisheries Management 15:419-427.

Sullivan, C. 1956. The importance of size grouping in population estimates employing electric shockers. Progressive Fish-Culturist 18:188-190.

Temple, A.J., W.E. Ensign, and R.J. Neves. 1998. Chapter 9: The effects of fright bias on sampling efficiency for stream fish assemblages. Pages 13-28 in Kolz, A.L., J. Reynolds, A. Temple, J. Boardman, and D. Lam, editors. Principles and Techniques of Electrofishing, U.S. Fish and Wildlife Service, National Conservation Training Center, Branch of Aquatic Resources Training, Shepherdstown, WV.

Vadas, R.L. and D.J. Orth. 1993. A new technique for estimating abundance and habitat use of stream fishes. Journal of Freshwater Ecology 8(4):305-317. 
Walsh, M.G. D.B. Fenner and D.L. Winkelman. 2002. Comparison of an electrical seine and prepositioned area electrofishers for sampling stream fish communities. North American Journal of Fisheries Management 22:77-85.

Weaver, M.J., J.J. Magnuson and M.K. Clayton. 1993. Analyses for differentiating littoral fish assemblages with catch data from multiple sampling gears. Transactions of the American Fisheries Society 122:1111-1119.

White, G.C., D.R. Anderson, K.P. Burnham and D.L. Otis. 1982. Capture-recapture and removal methods for sampling closed populations. Los Alamos National Laboratory, LA-8787-NERP, Los Alamos, New Mexico.

Wiley, M.L. and C. Tsai. 1983. The relative efficiencies of electrofishing vs. seines in Piedmont streams of Maryland. North American Journal of Fisheries Management 3:243-253.

Zippin, C. 1956. An evaluation of the removal method of estimating animal populations. Biometrics 12:163-189. 
Table 1. Location and characterstics of 10 study segments in the upper Greenbrier River watershed, West Virginia. Latitude, longitude and elevation are from the mid-point between compared sections. Strahler's stream orders were calculated on a 1:24,000 USGS Topo map and stream conductivities of sites are given. Averages for habitat variables used as covariates are listed for all sites sampled with backpack (BP) and parallel wires (PW) gears with standard errors (SE).

\begin{tabular}{|c|c|c|c|c|c|c|c|c|c|c|c|}
\hline Stream (site no.) & Latitude & Longitude & $\begin{array}{l}\text { Elevation } \\
\text { (m) }\end{array}$ & $\begin{array}{l}\text { Stream } \\
\text { Order }\end{array}$ & $\begin{array}{l}\text { Conductivity } \\
\text { (uS/cm) }\end{array}$ & Gear & $\begin{array}{l}\text { Site length } \\
\text { (m) }\end{array}$ & $\begin{array}{l}\text { Velocity } \\
(\mathrm{m} / \mathrm{s})\end{array}$ & $\begin{array}{l}\text { Substrate } \\
(\mathrm{mm})\end{array}$ & $\begin{array}{l}\text { Width } \\
(\mathrm{m})\end{array}$ & $\begin{array}{l}\text { Depth } \\
(\mathrm{m})\end{array}$ \\
\hline Upper Knapp (1) & $38^{\circ} 16.33^{\prime} \mathrm{N}$ & $79^{\circ} 51.54^{\prime} \mathrm{W}$ & 831 & 2 & 64 & $\begin{array}{l}\text { BP } \\
\text { PW }\end{array}$ & $\begin{array}{l}25.0 \\
25.0\end{array}$ & $\begin{array}{l}0.09(0.01) \\
0.11(0.01)\end{array}$ & $\begin{array}{l}135(15) \\
172(20)\end{array}$ & $\begin{array}{l}5.5(0.3) \\
4.2(0.3)\end{array}$ & $\begin{array}{l}0.05(0.004) \\
0.06(0.004)\end{array}$ \\
\hline Galford Run (2) & $38^{\circ} 22.39^{\prime} \mathrm{N}$ & $79^{\circ} 48.64^{\prime} \mathrm{W}$ & 851 & 2 & 49 & $\begin{array}{l}\text { BP } \\
\text { PW }\end{array}$ & $\begin{array}{l}20.0 \\
20.0\end{array}$ & $\begin{array}{l}0.11(0.01) \\
0.11(0.01)\end{array}$ & $\begin{array}{l}114(7) \\
114(8)\end{array}$ & $\begin{array}{c}4.7(0.04) \\
4.3(0.1)\end{array}$ & $\begin{array}{l}0.05(0.004) \\
0.06(0.004)\end{array}$ \\
\hline Little River of West Fork (3) & $38^{\circ} 37.01{ }^{\prime} \mathrm{N}$ & $79^{\circ} 48.29^{\prime} \mathrm{W}$ & 897 & 3 & 31 & $\begin{array}{l}\text { BP } \\
\text { PW }\end{array}$ & $\begin{array}{l}20.0 \\
20.0\end{array}$ & $\begin{array}{l}0.24(0.02) \\
0.16(0.02)\end{array}$ & $\begin{array}{l}80(6) \\
87(7)\end{array}$ & $\begin{array}{l}7.4(0.5) \\
8.7(0.4)\end{array}$ & $\begin{array}{l}0.11(0.006) \\
0.12(0.007)\end{array}$ \\
\hline West Fork (4) & $38^{\circ} 40.36^{\prime} \mathrm{N}$ & $79^{\circ} 47.37^{\prime} \mathrm{W}$ & 913 & 2 & 68 & $\begin{array}{l}\text { BP } \\
\text { PW }\end{array}$ & $\begin{array}{l}15.0 \\
15.0\end{array}$ & $\begin{array}{l}0.12(0.01) \\
0.08(0.01)\end{array}$ & $\begin{array}{l}170(11) \\
191(18)\end{array}$ & $\begin{array}{l}8.9(0.7) \\
9.6(0.4)\end{array}$ & $\begin{array}{c}0.09(0.004) \\
0.08(0.005)\end{array}$ \\
\hline East Fork (5) & $38^{\circ} 32.90 \prime \mathrm{N}$ & $79^{\circ} 45.70^{\prime} \mathrm{W}$ & 862 & 4 & 57 & $\begin{array}{l}\text { BP } \\
\text { PW }\end{array}$ & $\begin{array}{l}20.0 \\
20.0\end{array}$ & $\begin{array}{l}0.17(0.02) \\
0.16(0.02)\end{array}$ & $\begin{array}{l}125(11) \\
127(15)\end{array}$ & $\begin{array}{l}5.5(0.2) \\
5.8(0.4)\end{array}$ & $\begin{array}{l}0.11(0.008) \\
0.10(0.007)\end{array}$ \\
\hline Little River of East Fork (6) & $38^{\circ} 32.95^{\prime} \mathrm{N}$ & $79^{\circ} 43.81^{\prime} \mathrm{W}$ & 893 & 3 & 65 & $\begin{array}{l}\text { BP } \\
\text { PW }\end{array}$ & $\begin{array}{l}20.0 \\
20.0\end{array}$ & $\begin{array}{l}0.30(0.02) \\
0.36(0.02)\end{array}$ & $\begin{array}{l}134(15) \\
174(15)\end{array}$ & $\begin{array}{l}6.5(0.2) \\
6.2(0.6)\end{array}$ & $\begin{array}{l}0.19(0.008) \\
0.17(0.008)\end{array}$ \\
\hline East Fork (7) & $38^{\circ} 34.52^{\prime} \mathrm{N}$ & $79^{\circ} 43.00^{\prime} \mathrm{W}$ & 905 & 3 & 37 & $\begin{array}{l}\text { BP } \\
\text { PW }\end{array}$ & $\begin{array}{l}20.0 \\
20.0\end{array}$ & $\begin{array}{l}0.14(0.01) \\
0.11(0.01)\end{array}$ & $\begin{array}{l}119(9) \\
124(8)\end{array}$ & $\begin{array}{l}6.5(0.4) \\
6.9(0.4)\end{array}$ & $\begin{array}{l}0.09(0.007) \\
0.10(0.007)\end{array}$ \\
\hline East Fork (8) & $38^{\circ} 34.59^{\prime} \mathrm{N}$ & $79^{\circ} 42.87^{\prime} \mathrm{W}$ & 907 & 3 & 37 & $\begin{array}{l}\text { BP } \\
\text { PW }\end{array}$ & $\begin{array}{l}20.0 \\
20.0\end{array}$ & $\begin{array}{l}0.08(0.01) \\
0.08(0.01)\end{array}$ & $\begin{array}{l}216(24) \\
323(47)\end{array}$ & $\begin{array}{l}9.1(0.2) \\
8.7(0.3)\end{array}$ & $\begin{array}{l}0.11(0.007) \\
0.08(0.007)\end{array}$ \\
\hline East Fork (9) & $38^{\circ} 34.62^{\prime} \mathrm{N}$ & $79^{\circ} 42.63^{\prime} \mathrm{W}$ & 910 & 3 & 37 & $\begin{array}{l}\text { BP } \\
\text { PW }\end{array}$ & $\begin{array}{l}20.0 \\
20.0\end{array}$ & $\begin{array}{l}0.14(0.01) \\
0.15(0.02)\end{array}$ & $\begin{array}{l}204(21) \\
210(24)\end{array}$ & $\begin{array}{l}7.3(0.4) \\
8.0(0.5)\end{array}$ & $\begin{array}{l}0.13(0.008) \\
0.12(0.009)\end{array}$ \\
\hline Long Run (10) & $38^{\circ} 34.56^{\prime} \mathrm{N}$ & $79^{\circ} 42.14^{\prime} \mathrm{W}$ & 929 & 3 & 69 & $\begin{array}{l}\text { BP } \\
\text { PW }\end{array}$ & $\begin{array}{l}15.0 \\
15.0\end{array}$ & $\begin{array}{l}0.12(0.02) \\
0.15(0.02)\end{array}$ & $\begin{array}{c}88(7) \\
122(13)\end{array}$ & $\begin{array}{l}8.1(0.6) \\
7.1(0.4)\end{array}$ & $\begin{array}{l}0.07(0.005) \\
0.07(0.005)\end{array}$ \\
\hline
\end{tabular}


Table 2. Candidate capture efficiency models and associated model selection statistics for captures of western blacknose dace with parallel wire and backpack electrofishing gears at 10 paired sites (upper Greenbrier River drainage, WV) for the first (A), cumulative-second (B), and cumulative-third (C) sampling occasions including the number of parameters $(K)$, the second order adjustment of the Akaike information criterion $\left(\mathrm{AIC}_{\mathrm{c}}\right)$, difference in $\operatorname{AIC}_{\mathrm{c}}\left(\Delta_{i}\right)$, and the Akaike weights $\left(w_{i}\right)$ for each model.

\begin{tabular}{lccccc}
\hline Model & $-2 \log$ likelihood & $K$ & $\mathrm{AIC}_{\mathrm{c}}$ & $\Delta_{\mathrm{i}}$ & $w_{\mathrm{i}}$ \\
\hline Gear + stream width & 6133.190 & 3 & 6139.207 & 0.000 & 1.000 \\
Gear + rock size & 6152.090 & 3 & 6158.107 & 18.900 & 0.000 \\
Gear & 6155.080 & 2 & 6159.089 & 19.881 & 0.000 \\
Stream segment + stream width & 6174.520 & 10 & 6194.677 & 55.470 & 0.000 \\
Stream segment + stream depth & 6177.960 & 10 & 6198.117 & 58.910 & 0.000 \\
Stream segment + current velocity & 6178.580 & 10 & 6198.737 & 59.530 & 0.000 \\
Stream segment + rock size & 6206.290 & 10 & 6226.447 & 87.240 & 0.000 \\
Gear + stream depth & 6216.930 & 3 & 6222.947 & 83.740 & 0.000 \\
Gear + current velocity & 6228.540 & 3 & 6234.557 & 95.350 & 0.000 \\
Site saturated & 6257.440 & 18 & 6293.931 & 154.724 & 0.000 \\
\hline
\end{tabular}

B.

\begin{tabular}{lccccc}
\hline Model & $-2 \log$ likelihood & $K$ & $\mathrm{AIC}_{\mathrm{c}}$ & $\Delta_{\mathrm{i}}$ & $w_{\mathrm{i}}$ \\
\hline Gear + stream width & 6667.590 & 3 & 6673.607 & 0.000 & 1.000 \\
Stream segment + stream depth & 6773.490 & 10 & 6793.647 & 120.040 & 0.000 \\
Stream segment + stream width & 6780.850 & 10 & 6801.007 & 127.400 & 0.000 \\
Gear + rock size & 6788.880 & 3 & 6794.897 & 121.290 & 0.000 \\
Gear & 6790.880 & 2 & 6794.889 & 121.281 & 0.000 \\
Stream segment + rock size & 6795.560 & 10 & 6815.717 & 142.110 & 0.000 \\
Stream segment + current velocity & 6804.080 & 10 & 6824.237 & 150.630 & 0.000 \\
Gear + stream depth & 6838.710 & 3 & 6844.727 & 171.120 & 0.000 \\
Site saturated & 6918.750 & 18 & 6955.241 & 281.634 & 0.000 \\
Gear + current velocity & 6944.720 & 3 & 6950.737 & 277.130 & 0.000 \\
\hline
\end{tabular}

C.

\begin{tabular}{lccccc}
\hline Model & $-2 \log$ likelihood & $K$ & $\mathrm{AIC}_{\mathrm{c}}$ & $\Delta_{\mathrm{i}}$ & $w_{\mathrm{i}}$ \\
\hline Gear + stream width & 7479.370 & 3 & 7485.387 & 0.000 & 1.000 \\
Gear & 7499.460 & 2 & 7503.469 & 18.081 & 0.000 \\
Gear + rock size & 7507.890 & 3 & 7513.907 & 28.520 & 0.000 \\
Gear + stream depth & 7533.110 & 3 & 7539.127 & 53.740 & 0.000 \\
Stream segment + stream depth & 7552.610 & 10 & 7572.767 & 87.380 & 0.000 \\
Gear + current velocity & 7553.130 & 3 & 7559.147 & 73.760 & 0.000 \\
Stream segment + rock size & 7567.560 & 10 & 7587.717 & 102.330 & 0.000 \\
Stream segment + stream width & 7590.770 & 10 & 7610.927 & 125.540 & 0.000 \\
Stream segment + current velocity & 7618.910 & 10 & 7639.067 & 153.680 & 0.000 \\
Site saturated & 7698.850 & 18 & 7735.341 & 249.954 & 0.000 \\
\hline
\end{tabular}


Table 3. Candidate capture efficiency models and associated model selection statistics for captures of fantail darter with parallel wire and backpack electrofishing gears at 10 paired sites (upper Greenbrier River drainage, WV) for the first (A), cumulative-second (B), and cumulative-third (C) sampling occasions including the number of parameters $(K)$, the second order adjustment of the Akaike information criterion $\left(\mathrm{AIC}_{\mathrm{c}}\right)$, difference in $\mathrm{AIC}_{\mathrm{c}}\left(\Delta_{i}\right)$, and the Akaike weights $\left(w_{i}\right)$ for each model.

\begin{tabular}{lccccc}
\hline Aodel & $-2 \log$ likelihood & $K$ & $\mathrm{AIC}_{\mathrm{c}}$ & $\Delta_{\mathrm{i}}$ & $w_{\mathrm{i}}$ \\
\hline Gear & 16162.890 & 2 & 16166.893 & 0.000 & 0.999 \\
Gear + rock size & 16175.860 & 3 & 16181.866 & 14.973 & 0.001 \\
Gear + current velocity & 16214.910 & 3 & 16220.916 & 54.023 & 0.000 \\
Gear + stream width & 16247.210 & 3 & 16253.216 & 86.323 & 0.000 \\
Gear + stream depth & 16282.780 & 3 & 16288.786 & 121.893 & 0.000 \\
Stream segment + stream depth & 16364.670 & 11 & 16386.739 & 219.846 & 0.000 \\
Stream segment + rock size & 16365.270 & 11 & 16387.339 & 220.446 & 0.000 \\
Stream segment + current velocity & 16365.670 & 11 & 16387.739 & 220.846 & 0.000 \\
Stream segment + stream width & 16373.010 & 11 & 16395.079 & 228.186 & 0.000 \\
Site saturated & 16463.860 & 20 & 16504.080 & 337.187 & 0.000 \\
\hline
\end{tabular}

B.

\begin{tabular}{lccccc}
\hline Model & $-2 \log$ likelihood & $K$ & $\mathrm{AIC}_{\mathrm{c}}$ & $\Delta_{\mathrm{i}}$ & $w_{\mathrm{i}}$ \\
\hline Gear + stream width & 16614.620 & 3 & 16620.626 & 0.000 & 1.000 \\
Gear & 16756.820 & 2 & 16760.823 & 140.197 & 0.000 \\
Gear + rock size & 16854.810 & 3 & 16860.816 & 240.190 & 0.000 \\
Gear + current velocity & 16857.120 & 3 & 16863.126 & 242.500 & 0.000 \\
Gear + stream depth & 17011.400 & 3 & 17017.406 & 396.780 & 0.000 \\
Stream segment + current velocity & 17225.260 & 11 & 17247.329 & 626.703 & 0.000 \\
Stream segment + rock size & 17233.210 & 11 & 17255.279 & 634.653 & 0.000 \\
Stream segment + stream width & 17234.410 & 11 & 17256.479 & 635.853 & 0.000 \\
Stream segment + stream depth & 17235.670 & 11 & 17257.739 & 637.113 & 0.000 \\
Site saturated & 17403.980 & 20 & 17444.200 & 823.573 & 0.000 \\
\hline
\end{tabular}

C.

\begin{tabular}{lccccc}
\hline Model & $-2 \log$ likelihood & $K$ & $\mathrm{AIC}_{\mathrm{c}}$ & $\Delta_{\mathrm{i}}$ & $w_{\mathrm{i}}$ \\
\hline Gear + stream width & 18132.300 & 3 & 17908.846 & 0.000 & 1.000 \\
Gear & 18192.740 & 2 & 18136.303 & 227.457 & 0.000 \\
Gear + current velocity & 18192.740 & 3 & 18198.746 & 289.900 & 0.000 \\
Gear + rock size & 18340.690 & 3 & 18358.676 & 449.830 & 0.000 \\
Gear + stream depth & 18340.690 & 3 & 18417.276 & 508.430 & 0.000 \\
Stream segment + current velocity & 18539.410 & 11 & 18561.479 & 652.633 & 0.000 \\
Stream segment + rock size & 18541.530 & 11 & 18565.849 & 657.003 & 0.000 \\
Stream segment + stream depth & 18546.490 & 11 & 18568.559 & 659.713 & 0.000 \\
Stream segment + stream width & 18556.020 & 11 & 18578.089 & 669.243 & 0.000 \\
Site saturated & 18731.880 & 20 & 18772.100 & 863.253 & 0.000 \\
\hline
\end{tabular}


Table 4. Candidate capture efficiency models and associated model selection statistics for captures of mottled sculpin with parallel wire and backpack electrofishing gears at 10 paired sites (upper Greenbrier River drainage, WV) for the first (A), cumulative-second (B), and cumulative-third (C) sampling occasions including the number of parameters $(K)$, the second order adjustment of the Akaike information criterion $\left(\mathrm{AIC}_{\mathrm{c}}\right)$, difference in $\mathrm{AIC}_{\mathrm{c}}\left(\Delta_{i}\right)$, and the Akaike weights $\left(w_{i}\right)$ for each model.

\begin{tabular}{lccccc}
\hline Aodel & $-2 \log$ likelihood & $K$ & $\mathrm{AIC}_{\mathrm{c}}$ & $\Delta_{\mathrm{i}}$ & $w_{\mathrm{i}}$ \\
\hline Gear & 9699.810 & 2 & 9703.815 & 0.000 & 0.884 \\
Gear + rock size & 9702.710 & 3 & 9708.720 & 4.905 & 0.076 \\
Gear + stream width & 9704.040 & 3 & 9710.050 & 6.235 & 0.039 \\
Gear + current velocity & 9712.400 & 3 & 9718.410 & 14.595 & 0.001 \\
Gear + stream depth & 9737.170 & 3 & 9743.180 & 39.365 & 0.000 \\
Stream segment + stream width & 9763.690 & 11 & 9785.806 & 81.990 & 0.000 \\
Stream segment + current velocity & 9763.710 & 11 & 9785.826 & 82.010 & 0.000 \\
Stream segment + rock size & 9767.120 & 11 & 9789.236 & 85.420 & 0.000 \\
Stream segment + stream depth & 9767.450 & 11 & 9789.566 & 85.750 & 0.000 \\
Site saturated & 9788.490 & 20 & 9828.859 & 125.044 & 0.000 \\
\hline
\end{tabular}

B.

\begin{tabular}{lccccc}
\hline Model & $-2 \log$ likelihood & $K$ & $\mathrm{AIC}_{\mathrm{c}}$ & $\Delta_{\mathrm{i}}$ & $w_{\mathrm{i}}$ \\
\hline Gear & 9975.880 & 2 & 9979.885 & 0.000 & 0.517 \\
Gear + rock size & 9974.010 & 3 & 9980.020 & 0.135 & 0.483 \\
Gear + current velocity & 10012.410 & 3 & 10018.420 & 38.535 & 0.000 \\
Gear + stream width & 10049.590 & 3 & 10055.600 & 75.715 & 0.000 \\
Gear + stream depth & 10105.080 & 3 & 10111.090 & 131.205 & 0.000 \\
Stream segment + rock size & 10133.940 & 11 & 10156.056 & 176.170 & 0.000 \\
Stream segment + stream width & 10134.070 & 11 & 10156.186 & 176.300 & 0.000 \\
Stream segment + current velocity & 10134.400 & 11 & 10156.516 & 176.630 & 0.000 \\
Stream segment + stream depth & 10135.990 & 11 & 10158.106 & 178.220 & 0.000 \\
Site saturated & 10163.480 & 20 & 10203.849 & 223.964 & 0.000 \\
\hline
\end{tabular}

C.

\begin{tabular}{lccccc}
\hline Model & $-2 \log$ likelihood & $K$ & $\mathrm{AIC}_{\mathrm{c}}$ & $\Delta_{\mathrm{i}}$ & $w_{\mathrm{i}}$ \\
\hline Gear & 10672.420 & 2 & 10676.425 & 0.000 & 1.000 \\
Gear + rock size & 10701.080 & 3 & 10707.090 & 30.665 & 0.000 \\
Gear + current velocity & 10727.960 & 3 & 10733.970 & 57.545 & 0.000 \\
Gear + stream width & 10802.240 & 3 & 10808.250 & 131.825 & 0.000 \\
Gear + stream depth & 10864.820 & 3 & 10870.830 & 194.405 & 0.000 \\
Stream segment + rock size & 10930.260 & 11 & 10952.376 & 275.950 & 0.000 \\
Stream segment + stream depth & 10930.600 & 11 & 10952.716 & 276.290 & 0.000 \\
Stream segment + current velocity & 10931.070 & 11 & 10953.186 & 276.760 & 0.000 \\
Stream segment + stream width & 10931.700 & 11 & 10953.816 & 277.390 & 0.000 \\
Site saturated & 10957.730 & 20 & 10998.099 & 321.674 & 0.000 \\
\hline
\end{tabular}


Table 5. Species abundances $(\hat{N})$ and capture probabilities $(\hat{p})$ estimated from four-pass removal studies with backpack and parallel wire electrofishing gears at 10 paired sites in the upper Greenbrier River drainage, West Virginia. Total counts from seven and four sampling occasions are provided for adults (A) and juveniles (J) of each species. Abundance estimates, standard error (SE, parenthetic for $\hat{p}$ ), and lower (LCL) and upper (UCL) 95\% confidence limits are provided when four-pass sample sizes exceed 40 individuals. An asterisk adjacent to a four-pass count indicates failure of removal depletion.

\begin{tabular}{|c|c|c|c|c|c|c|c|c|c|}
\hline $\begin{array}{l}\text { Species by stream } \\
\text { segment and gear }\end{array}$ & $\begin{array}{c}\text { Total } \\
\text { 7-pass }\end{array}$ & $\begin{array}{l}\text { Total } \\
\text { 4-pass }\end{array}$ & $\hat{N}$ & SE & LCL & UCL & $\hat{p}_{2}$ & $\hat{p}_{3}$ & $\hat{p}_{4}$ \\
\hline \multicolumn{10}{|l|}{ Segment 1 (Knapp Creek) } \\
\hline \multicolumn{10}{|l|}{ Backpack } \\
\hline Rhinichthys obtusus & 178 & 167 & 174 & 5.0 & 169 & 192 & $0.52(0.04) 0.55(0.07)$ & $0.55(0.07)$ & $0.55(0.07)$ \\
\hline Etheostoma flabellare & 475 & 443 & 476 & 16.0 & 456 & 524 & $0.66(0.08) 0.41(0.07)$ & $0.41(0.07)$ & $0.41(0.07)$ \\
\hline Cottus bairdi & 155 & $147 *$ & - & - & - & - & - & - & - \\
\hline \multicolumn{10}{|l|}{ Parallel Wires } \\
\hline Rhinichthys obtusus & 193 & 184 & 200 & 12.4 & 188 & 245 & $0.66(0.05) 0.38(0.11)$ & $0.38(0.11)$ & $0.38(0.11)$ \\
\hline Etheostoma flabellare & 373 & 338 & 358 & 9.6 & 346 & 387 & $0.56(0.03) 0.49(0.06)$ & $0.49(0.06)$ & $0.49(0.06)$ \\
\hline Cottus bairdi & 141 & 130 & 136 & 5.2 & 132 & 156 & $0.55(0.05) 0.52(0.09)$ & $0.52(0.09)$ & $0.52(0.09)$ \\
\hline \multicolumn{10}{|l|}{ Segment 2 (Galford Run) } \\
\hline \multicolumn{10}{|l|}{ Backpack } \\
\hline Rhinichthys obtusus & 62 & $58 *$ & - & - & - & - & - & - & - \\
\hline Etheostoma flabellare & 334 & 308 & 365 & 58.9 & 319 & 611 & $0.47(0.08) 0.42(0.13)$ & $0.42(0.13)$ & $0.42(0.13)$ \\
\hline Cottus bairdi & 223 & 202 & 211 & 6.0 & 205 & 233 & $0.52(0.04) 0.54(0.07)$ & $0.54(0.07)$ & $0.54(0.07)$ \\
\hline \multicolumn{10}{|l|}{ Parallel Wires } \\
\hline Rhinichthys obtusus & 132 & 128 & 128 & 0.0 & 128 & 128 & $0.83(0.03) 0.73(0.09)$ & $0.86(0.13)$ & $0.86(0.13)$ \\
\hline Etheostoma flabellare & 260 & 242 & 245 & 4.2 & 243 & 265 & $0.66(0.03) 0.58(0.06)$ & $0.66(0.14)$ & $0.66(0.14)$ \\
\hline Cottus bairdi & 170 & 158 & 159 & 1.7 & 158 & 169 & $0.57(0.04) 0.57(0.06)$ & $0.80(0.10)$ & $0.80(0.10)$ \\
\hline
\end{tabular}

Segment 3 (Little River of West Fork)

\section{Backpack}

Rhinichthys obtusus

Etheostoma flabellare

Cottus bairdi

Parallel Wires

Rhinichthys obtusus

Etheostoma flabellare

Cottus bairdi

\begin{tabular}{|c|c|c|c|c|c|c|c|c|}
\hline 47 & 37 & - & - & - & - & - & - & - \\
\hline 233 & 208 & 346 & 110.1 & 243 & 756 & $0.29(0.10) 0.18(0.10)$ & $0.18(0.10)$ & $0.18(0.10)$ \\
\hline 120 & 100 & 110 & 8.7 & 102 & 144 & $0.52(0.06) 0.42(0.12)$ & $0.42(0.12)$ & $0.42(0.12)$ \\
\hline 100 & 98 & 98 & 1.3 & 98 & 107 & $0.73(0.05) 0.69(0.10)$ & $0.69(0.10)$ & $0.69(0.10)$ \\
\hline 21 & 282 & 292 & 5.4 & 286 & 309 & $0.51(0.03) 0.58(0.05)$ & $0.58(0.05)$ & $0.58(0.05)$ \\
\hline 126 & 104 & 110 & 5.0 & 105 & 128 & $0.26(0.04) 0.55(0.07)$ & 0.55 & $0.55(0.07)$ \\
\hline
\end{tabular}

Segment 4 (West Fork)

\section{Backpack}

Rhinichthys obtusus

Etheostoma flabellare

Cottus bairdi

Parallel Wires

Rhinichthys obtusus

Etheostoma flabellare

Cottus bairdi

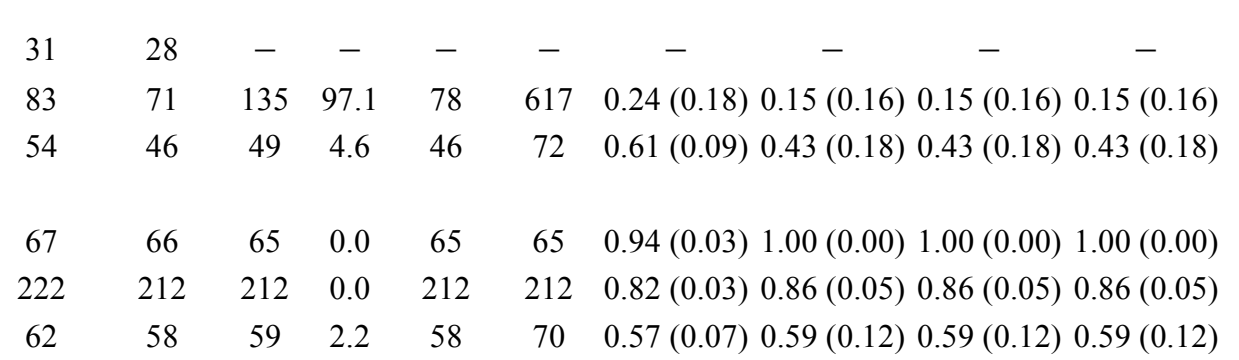


Table 5. continued

Segment 5 (East Fork)

Backpack

Rhinichthys obtusus

Etheostoma flabellar

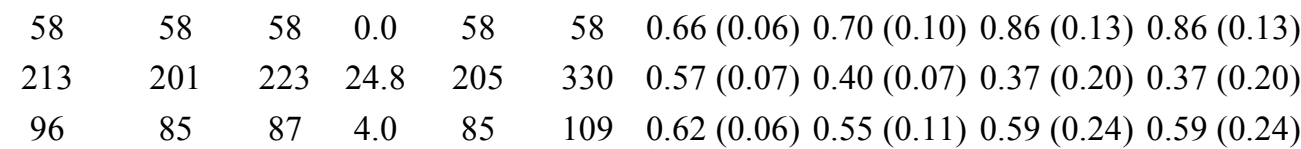

Cottus bairdi

Parallel Wires

Etheostoma flabellare

Cottus bairdi

$\begin{array}{cccccccccc}88 & 85 & 84 & 1.6 & 84 & 95 & 0.80(0.05) & 0.53(0.13) & 0.71(0.25) & 0.71(0.25) \\ 160 & 152 & 180 & 37.2 & 156 & 354 & 0.51(0.11) & 0.35(0.15) & 0.30(0.23) & 0.30(0.23) \\ 67 & 63^{*} & - & - & - & - & - & - & - & -\end{array}$

Segment 6 (Little River of East Fork)

Backpack

Etheostoma flabellare 197

Cottus bairdi

97

$\begin{array}{llll}78 & 78 & 1.6 & 78\end{array}$

$89 \quad 0.52(0.06) 0.59(0.08) 0.76(0.16) 0.76(0.16)$

Parallel Wires

Rhinichthys obtusus

Etheostoma flabellare 90

$152 *$

$63 *$

Cottus bairdi

$64 \quad 78$

$255 \quad 221$

$\begin{array}{lll}60 & 0.0 & 60\end{array}$

$\begin{array}{llllll}60 & 0.67(0.06) & 0.55(0.11) & 0.9(0.09) & 0.9(0.09)\end{array}$

$112 \quad 87$

$\begin{array}{lll}252 & 26.7 & 228\end{array}$

$3540.50(0.06) 0.29(0.07) 0.41(0.16) 0.41(0.16)$

$1130.44(0.08) 0.44(0.06) 0.62(0.17) 0.62(0.17)$

Segment 7 (East Fork)

Backpack

Rhinichthys obtusus

Etheostoma flabellare

56

53

$\begin{array}{lll}55 & 2.7 & 53\end{array}$

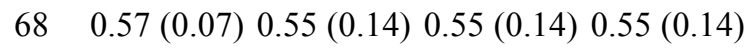

128

$\begin{array}{llll}108 & 125 & 12.9 & 113\end{array}$

$1720.42(0.06) 0.38(0.11) 0.38(0.11) 0.38(0.11)$

Cottus bairdi

153

$\begin{array}{llll}134 & 144 & 6.8 & 137\end{array}$

$167 \quad 0.42(0.05) 0.50(0.08) 0.50(0.08) 0.50(0.08)$

Parallel Wires

Rhinichthys obtusus

Etheostoma flabellare

50

$\begin{array}{llll}46 & 46 & 0.0 & 46\end{array}$

$46 \quad 0.78(0.06) 0.67(0.12) 0.67(0.12) 0.67(0.12)$

147

138

$\begin{array}{lll}143 & 4.2 & 139\end{array}$

$\begin{array}{lllll}159 & 0.53(0.04) & 0.56(0.08) & 0.56(0.08) & 0.56(0.08)\end{array}$

Cottus bairdi

136

120

$\begin{array}{lll}137 & 11.4 & 125\end{array}$

$176 \quad 0.40(0.05) 0.41(0.10) 0.41(0.10) 0.41(0.10)$

Segment 8 (East Fork)

Backpack

Rhinichthys obtusus

Etheostoma flabellare

Cottus bairdi

Parallel Wires

Rhinichthys obtusus

Etheostoma flabellare

$\begin{array}{ccccc}61 & 57 & 57 & 0.0 & 57 \\ 105 & 94 * & - & - & -\end{array}$

Cottus bairdi

20

$\begin{array}{ccccc}16 & - & - & - & - \\ 56 * & - & - & - & -\end{array}$

95

$\begin{array}{llll}77 & 81 & 5.9 & 78\end{array}$

$109 \quad 0.44(0.06) 0.40(0.09) 0.40(0.09) 0.40(0.09)$

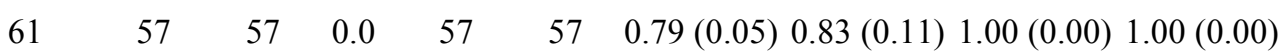

$\begin{array}{lllll}94 & 83 & 94 & 16.2 & 84\end{array}$

$173 \quad 0.49(0.10) 0.35(0.14) 0.39(0.25) 0.39(0.25)$ 
Table 5. continued

Segment 9 (East Fork)

Backpack

Rhinichthys obtusus

Etheostoma flabellare

Cottus bairdi

Parallel Wires

Rhinichthys obtusus

Etheostoma flabellare

Cottus bairdi

$\begin{array}{llllllll}73 & 64 & 67 & 4.0 & 64 & 85 & 0.55(0.07) 0.50(0.13) 0.50(0.13) 0.50(0.13) \\ 91 & 70 & 70 & 0.0 & 70 & 70 & 0.60(0.06) 0.74(0.07) 0.74(0.07) 0.74(0.07) \\ 85 & 70 & 72 & 2.9 & 70 & 85 & 0.47(0.06) 0.58(0.10) 0.58(0.10) 0.58(0.10)\end{array}$

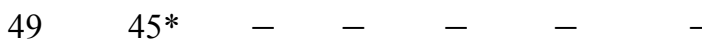

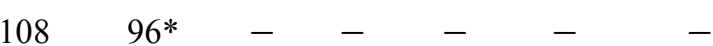

$83-62 * \quad-\quad-6 \quad-\quad-$

Segment 10 (Long Run)

Backpack

Rhinichthys obtusus

Etheostoma flabellare

-

Cottus bairdi

$38 \quad 3$

$\begin{array}{llll}16 & 120 & 5.8 & 117\end{array}$

177

Parallel Wires

Rhinichthys obtusus

Etheostoma flabellare

$\begin{array}{lllll}6 & 6 & - & - & -\end{array}$

Cottus bairdi

$25 \quad 24$

$113 \quad 101$

$103 \quad 2.9 \quad 101$

$1170.40(0.05) 0.45(0.07) 0.73(0.12) 0.73(0.12)$ 
Table 6. Mean capture efficiencies for the three commonly captured species with associated standard errors and lower and upper 95\% confidence interval (LCI and UCI).

\begin{tabular}{lcccc}
\hline & $\begin{array}{c}\text { Mean Capture } \\
\text { Efficiency }\end{array}$ & $\begin{array}{c}\text { Standard } \\
\text { Error }\end{array}$ & $\mathrm{LCl}$ & $\mathrm{UCl}$ \\
\hline $\begin{array}{l}\text { Parallel wires } \\
\text { R. obtusus }\end{array}$ & 0.734 & 0.034 & 0.668 & 0.800 \\
E. flabellare & 0.538 & 0.024 & 0.490 & 0.585 \\
C. bairdi & 0.439 & 0.031 & 0.379 & 0.499 \\
Backpack & & & & \\
R. obtusus & 0.551 & 0.041 & 0.472 & 0.631 \\
E. flabellare & 0.493 & 0.025 & 0.445 & 0.541 \\
C. bairdi & 0.484 & 0.031 & 0.424 & 0.544 \\
\hline
\end{tabular}

Table 7. Mean capture probabilities for the three commonly captured species with associated standard errors and lower and upper 95\% confidence intervals (LCI and UCI).

\begin{tabular}{lcccc}
\hline & $\begin{array}{c}\text { Mean capture } \\
\text { probability }\end{array}$ & $\begin{array}{c}\text { Standard } \\
\text { Error }\end{array}$ & $\mathrm{LCl}$ & $\mathrm{UCl}$ \\
\hline $\begin{array}{l}\text { Parallel wires } \\
\text { R. obtusus }\end{array}$ & 0.775 & 0.047 & 0.682 & 0.868 \\
E. flabellare & 0.584 & 0.049 & 0.489 & 0.680 \\
C. bairdi & 0.460 & 0.060 & 0.343 & 0.577 \\
$\begin{array}{l}\text { Backpack } \\
\text { R. obtusus }\end{array}$ & 0.564 & 0.056 & 0.453 & 0.675 \\
E. flabellare & 0.464 & 0.088 & 0.292 & 0.637 \\
C. bairdi & 0.523 & 0.055 & 0.414 & 0.631 \\
\hline
\end{tabular}




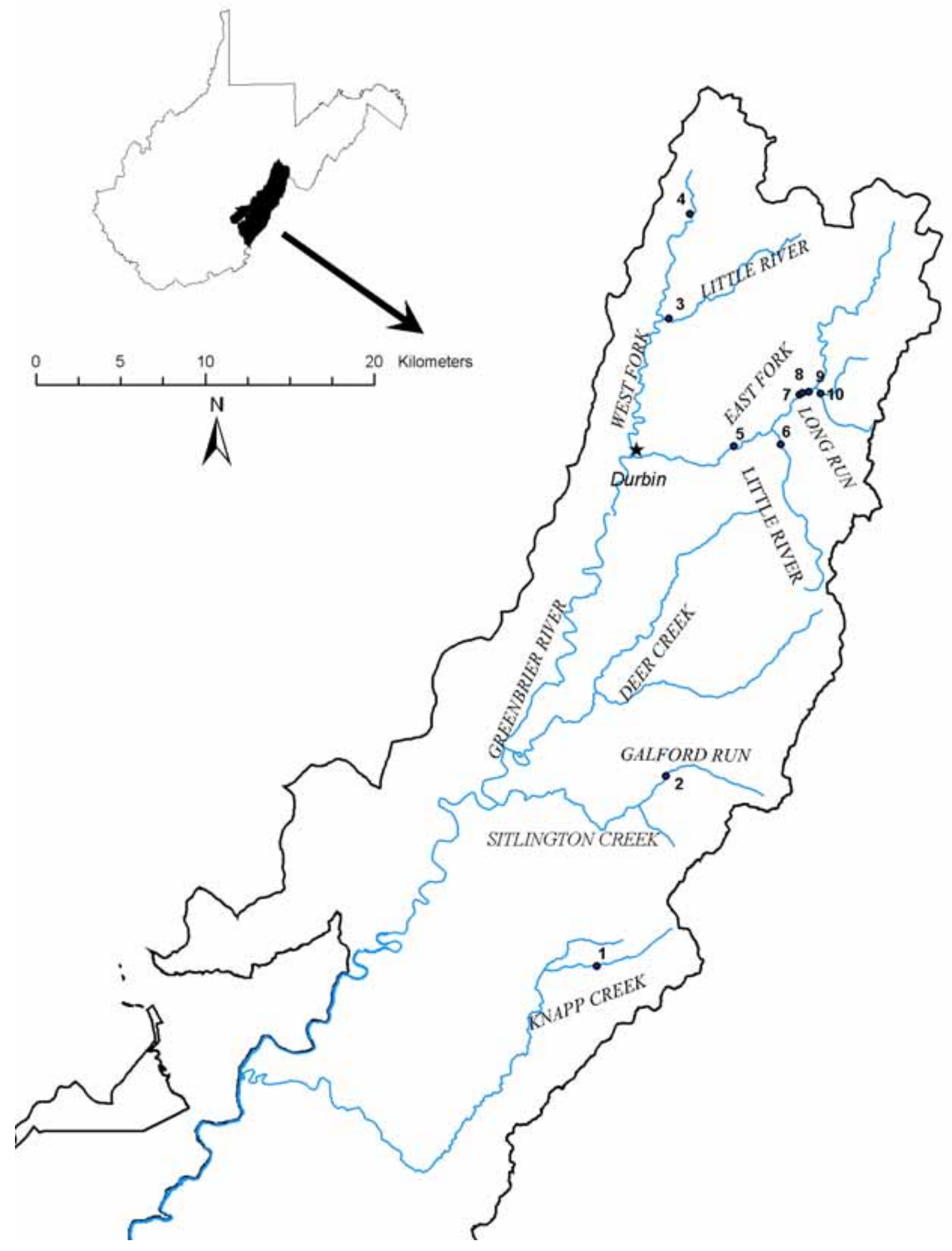

Figure 1. Locations of 10 study reaches (each with two sampling sites) in the upper Greenbrier River drainage, West Virginia, where capture efficiencies and fish abundances were estimated from removal sampling with parallel wire and backpack electrofishing methods. 

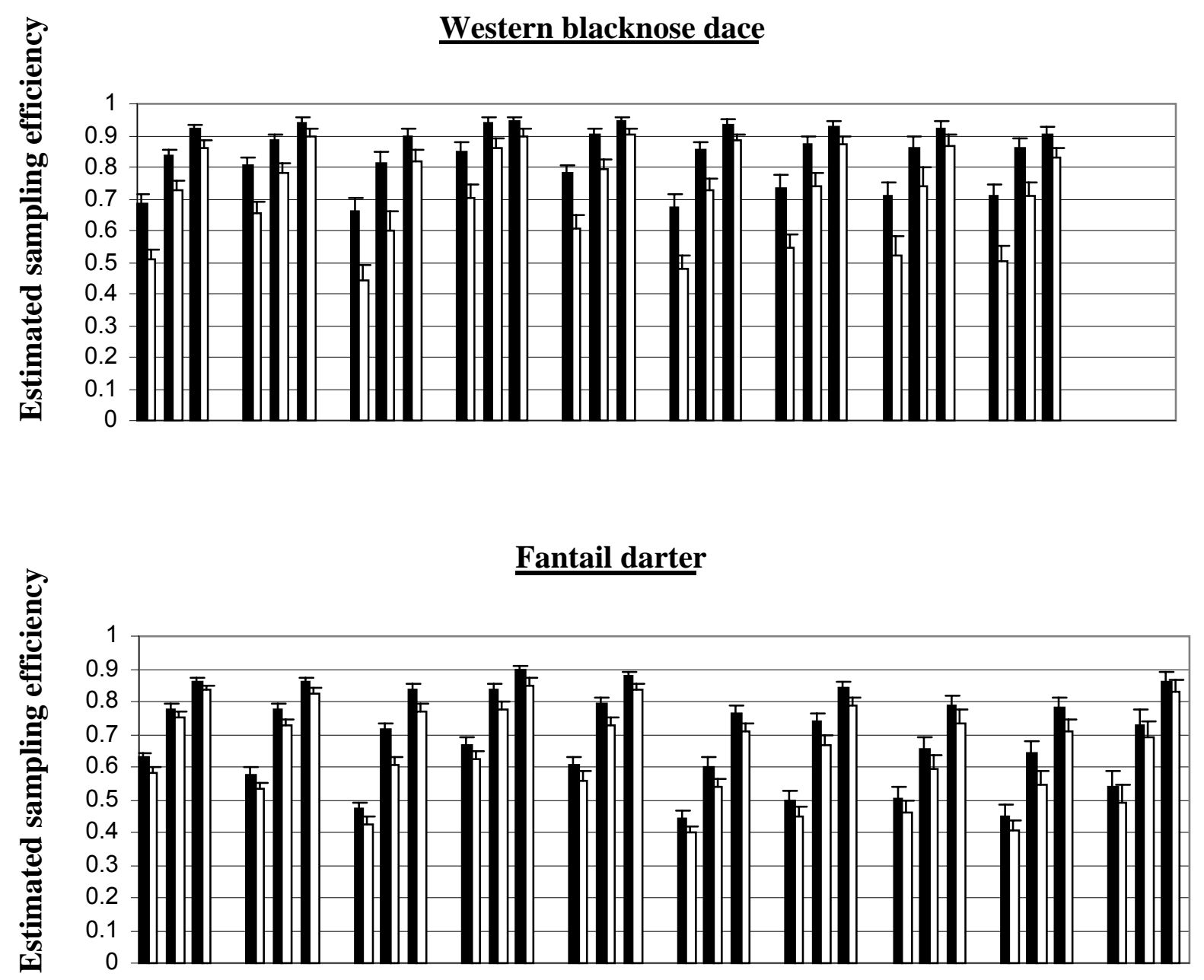

$\underline{\text { Mottled sculpin }}$

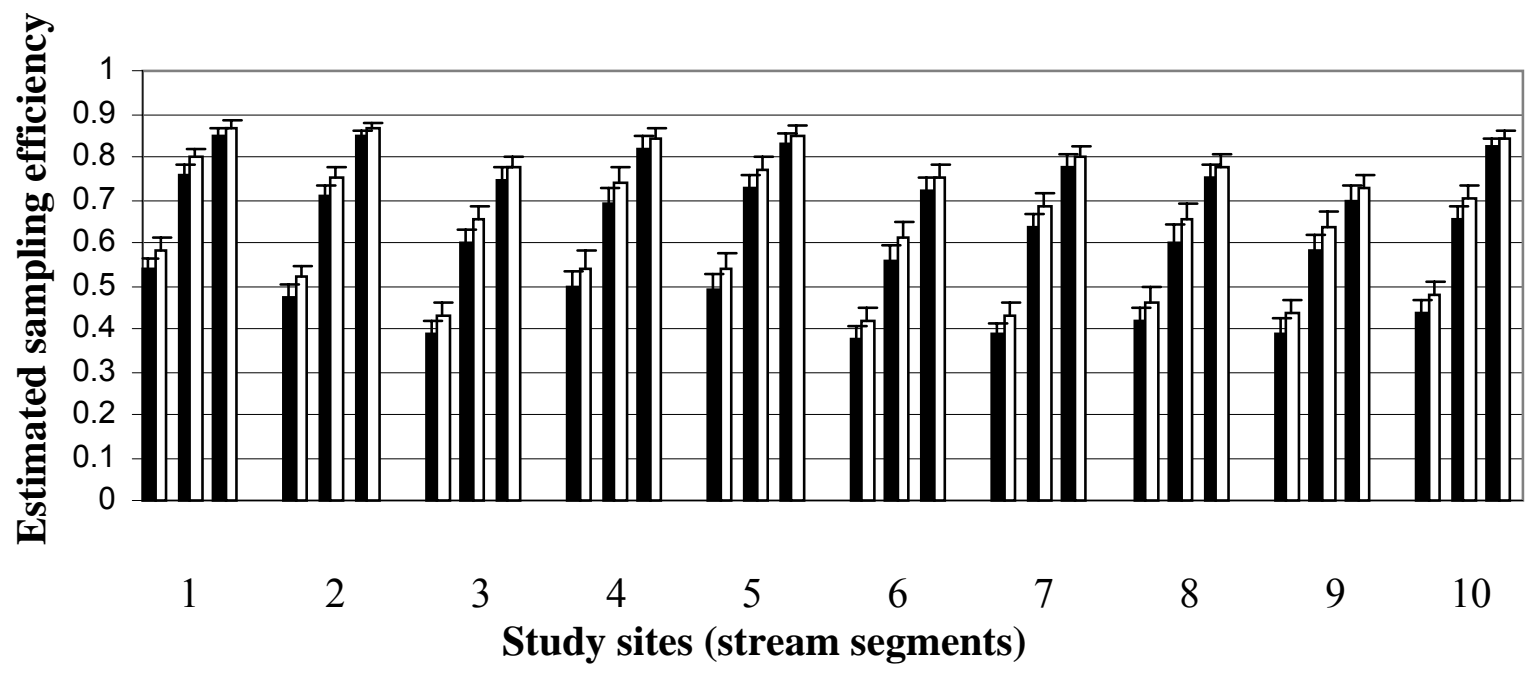

Figure 2. Capture efficiencies of parallel wires (closed) and backpack (open) electrofishers estimated from paired sites within 10 stream segments of the upper Greenbrier River drainage, WV. For each stream segment, estimates for paired sites (adjacent histogram bars) are provided for the first, cumulative-second, and cumulative-third electrofishing sampling occasions. 
Subrate Measure Comparions By Sites
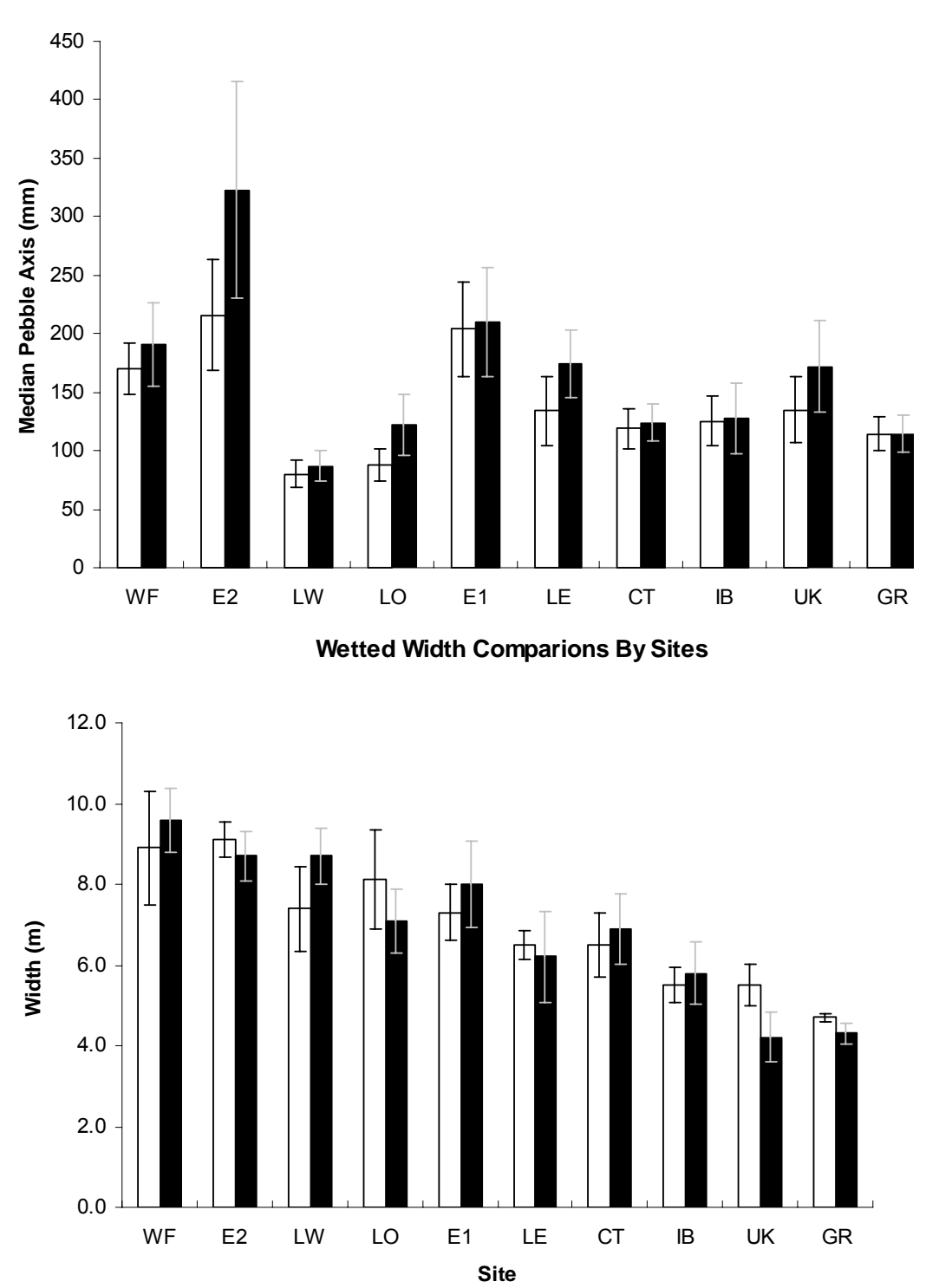

Velocity Measure Comparions By Sites

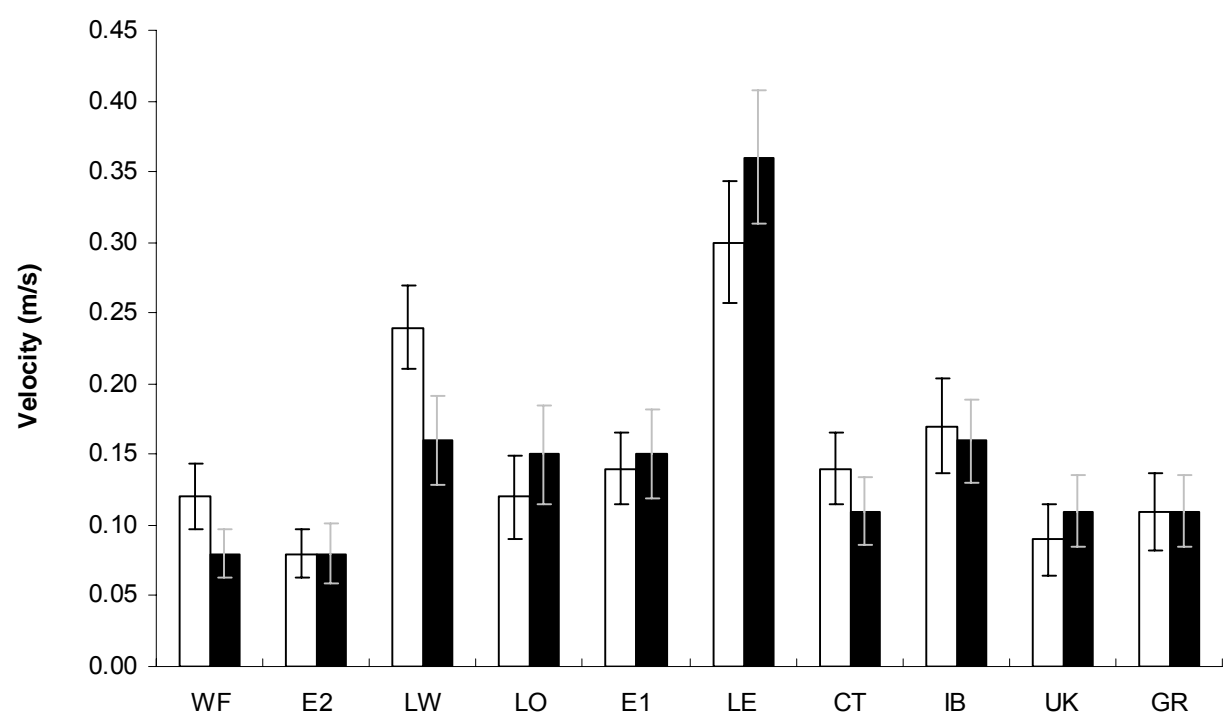

Depth Measure Comparions By Sites

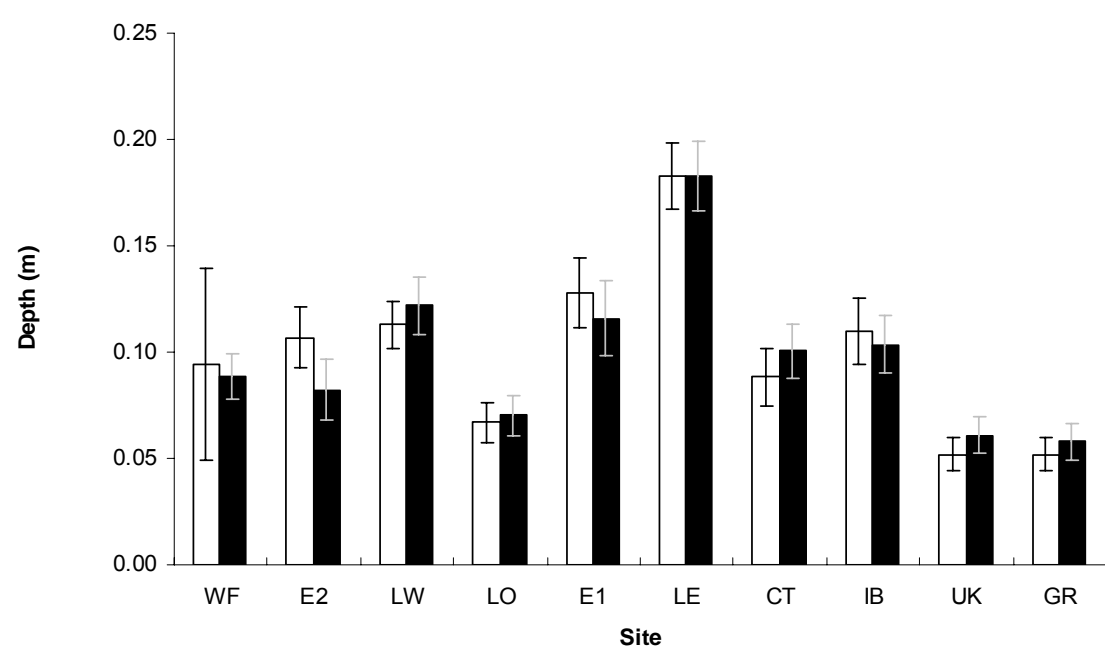

Appendix 1. Habitat variables (substrate, velocity, wetted width and depth) of parallel wires (closed) and backpack (open) electrofishers estimated from paired sites within 10 stream segments (site acronyms are presented in Appendix 3.1) of the upper Greenbrier River drainage, WV. For each stream segment, habitat averages with $95 \%$ CI are provided for the paired sites (adjacent histogram bars). 
Appendix 2. Species abundances $(\hat{N})$ and capture probabilities $(\hat{p})$ estimated from four-pass removal studies with backpack and parallel wire electrofishing gears at 10 paired sites in the upper Greenbrier River drainage, West Virginia. Total counts from seven and four sampling occasions are provided for adults (A) and juveniles (J) of each species. Abundance estimates, standard error (SE, parenthetic for $\hat{p}$ ), and lower (LCL) and upper (UCL) 95\% confidence limits are provided when four-pass sample sizes exceed 40 individuals. An asterisk adjacent to a fourpass count indicates failure of removal depletion. Site descriptions given in Appendix 3.1.

\begin{tabular}{|c|c|c|c|c|c|c|c|c|c|c|c|}
\hline $\begin{array}{l}\text { Species by stream } \\
\text { segment and gear }\end{array}$ & Age & $\begin{array}{l}\text { Total } \\
\text { 7-pass }\end{array}$ & $\begin{array}{l}\text { Total } \\
\text { 4-pass }\end{array}$ & $\hat{N}$ & SE & LCL & UCL & $\hat{p}_{1}$ & $\hat{p}_{2}$ & $\hat{p}_{3}$ & $\hat{p}_{4}$ \\
\hline \multicolumn{12}{|l|}{ Segment 1 (Knapp Creek) } \\
\hline \multicolumn{12}{|l|}{ Backpack } \\
\hline Campostoma anomalum & A & 7 & 7 & - & - & - & - & - & - & - & - \\
\hline Cottus bairdi & A & 155 & $147 *$ & - & - & - & - & - & - & - & - \\
\hline Cottus bairdi & $\mathrm{J}$ & 32 & 26 & - & - & - & - & - & - & - & - \\
\hline Etheostoma caeruleum & A & 4 & 4 & - & - & - & - & - & - & - & - \\
\hline Etheostoma flabellare & A & 475 & 443 & 476 & 16.0 & 524 & 456 & $0.66(0.08)$ & $0.41(0.07)$ & $0.41(0.07)$ & $0.41(0.07)$ \\
\hline Etheostoma flabellare & $\mathrm{J}$ & 28 & 18 & - & - & - & - & - & - & - & - \\
\hline Notropis telescopus & A & 4 & 4 & - & - & - & - & - & - & - & - \\
\hline Phoxinus oreas & A & 21 & 21 & - & - & - & - & - & - & - & - \\
\hline Phoxinus oreas & $\mathrm{J}$ & 1 & 1 & - & - & - & - & - & - & - & - \\
\hline Rhinichthys obtusus & A & 178 & 167 & 174 & 5.0 & 192 & 169 & $0.52(0.04)$ & $0.55(0.07)$ & $0.55(0.07)$ & $0.55(0.07)$ \\
\hline Rhinichthys obtusus & $\mathrm{J}$ & 14 & 10 & - & - & - & - & - & - & - & - \\
\hline Salvelinus fontinalis & $\mathrm{J}$ & 1 & 1 & - & - & - & - & - & - & - & - \\
\hline Semotilus atromaculatus & A & 3 & 3 & - & - & - & - & - & - & - & - \\
\hline Semotilus atromaculatus & $\mathrm{J}$ & 5 & 4 & - & - & - & - & - & - & - & - \\
\hline \multicolumn{12}{|l|}{ Parallel Wires } \\
\hline Campostoma anomalum & A & 128 & 119 & 139 & 16.8 & 202 & 124 & $0.50(0.07)$ & $0.33(0.12)$ & $0.33(0.12)$ & $0.33(0.12)$ \\
\hline Campostoma anomalum & $\mathrm{J}$ & 4 & 3 & - & - & - & - & - & - & - & - \\
\hline Cottus bairdi & $\mathrm{A}$ & 141 & 130 & 136 & 5.2 & 156 & 132 & $0.55(0.05)$ & $0.52(0.09)$ & $0.52(0.09)$ & $0.52(0.09)$ \\
\hline Cottus bairdi & $\mathrm{J}$ & 15 & 11 & - & - & - & - & - & - & - & - \\
\hline Etheostoma caeruleum & $\mathrm{A}$ & 1 & 1 & - & - & - & - & - & - & - & - \\
\hline Etheostoma flabellare & $\mathrm{A}$ & 373 & 338 & 358 & 9.6 & 387 & 346 & $0.56(0.03)$ & $0.49(0.06)$ & $0.49(0.06)$ & $0.49(0.06)$ \\
\hline Etheostoma flabellare & $\mathrm{J}$ & 17 & 16 & - & - & - & - & - & - & - & - \\
\hline Notropis telescopus & A & 16 & 16 & - & - & - & - & - & - & - & - \\
\hline Phoxinus oreas & A & 55 & 53 & 53 & 0.0 & 53 & 53 & $0.77(0.06)$ & $0.67(0.11)$ & $0.67(0.11)$ & $0.67(0.11)$ \\
\hline Rhinichthys obtusus & A & 193 & 184 & 200 & 12.4 & 245 & 188 & $0.66(0.05)$ & $0.38(0.11)$ & $0.38(0.11)$ & $0.38(0.11)$ \\
\hline Rhinichthys obtusus & $\mathrm{J}$ & 1 & 1 & - & - & - & - & - & - & - & - \\
\hline Salvelinus fontinalis & $\mathrm{J}$ & 1 & 1 & - & - & - & - & - & - & - & - \\
\hline Semotilus atromaculatus & A & 2 & 1 & - & - & - & - & - & - & - & - \\
\hline
\end{tabular}

Segment 2 (Galford Run)

\section{Backpack}

Campostoma anomalum

Campostoma anomalum

Cottus bairdi

$$
\begin{array}{ccccccccccc}
\text { A } & 9 & 7 & - & - & - & - & - & - & - & - \\
\mathrm{J} & 1 & 1 & - & - & - & - & - & - & - & - \\
\mathrm{A} & 223 & 202 & 211 & 6.0 & 233 & 205 & 0.52(0.04) & 0.54(0.07) & 0.54(0.07) & 0.54(0.07)
\end{array}
$$


Appendix 2. continued.

\begin{tabular}{|c|c|c|c|c|c|c|c|c|c|c|c|}
\hline Cottus bairdi & $\mathrm{J}$ & 99 & $78^{*}$ & - & - & - & - & - & - & - & - \\
\hline Etheostoma flabellare & A & 334 & 308 & 365 & 58.9 & 611 & 319 & $0.47(0.08)$ & $0.42(0.13)$ & $0.42(0.13)$ & $0.42(0.13)$ \\
\hline Etheostoma flabellare & $\mathbf{J}$ & 50 & 40 & 45 & 11.3 & 109 & 40 & $0.40(0.12)$ & $0.47(0.22)$ & $0.36(0.34)$ & $0.36(0.34)$ \\
\hline Rhinichthys obtusus & A & 62 & $58 *$ & - & - & - & - & - & - & - & - \\
\hline Rhinichthys obtusus & $\mathrm{J}$ & 34 & 30 & - & - & - & - & - & - & - & - \\
\hline \multicolumn{12}{|l|}{ Parallel Wires } \\
\hline Campostoma anomalum & A & 49 & 49 & - & - & - & - & - & - & - & - \\
\hline Campostoma anomalum & $\mathrm{J}$ & 26 & 26 & - & - & - & - & - & - & - & - \\
\hline Cottus bairdi & $\mathrm{A}$ & 170 & 158 & 159 & 1.7 & 169 & 158 & $0.57(0.04)$ & $0.57(0.06)$ & $0.80(0.10)$ & $0.80(0.10)$ \\
\hline Cottus bairdi & $\mathrm{J}$ & 97 & 80 & 97 & 25.9 & 225 & 82 & $0.34(0.10)$ & $0.41(0.18)$ & $0.32(0.26)$ & $0.32(0.26)$ \\
\hline Etheostoma flabellare & A & 260 & 242 & 245 & 4.2 & 265 & 243 & $0.66(0.03)$ & $0.58(0.06)$ & $0.66(0.14)$ & $0.66(0.14)$ \\
\hline Etheostoma flabellare & $\mathrm{J}$ & 58 & $53 *$ & - & - & - & - & - & - & - & - \\
\hline Rhinichthys obtusus & $\mathrm{A}$ & 132 & 128 & 128 & 0.0 & 128 & 128 & $0.83(0.03)$ & $0.73(0.09)$ & $0.86(0.13)$ & $0.86(0.13)$ \\
\hline Rhinichthys obtusus & $\mathrm{J}$ & 35 & 35 & - & - & - & - & - & - & - & - \\
\hline
\end{tabular}

Segment 3 (Little River of the West Fork)

\section{Backpack}

Cottus baird

Cottus bairdi

Etheostoma flabellare

Etheostoma flabellare

Etheostoma osburni

Etheostoma osburni

Lepomis cyanellus

Notropis telescopus

Rhinichthys obtusus

Rhinichthys cataractae

Semotilus atromaculatus

Parallel Wires

Campostoma anomalum

Campostoma anomalum

Clinostomus funduloides

Clinostomus funduloides

Cottus bairdi

Cottus bairdi

Etheostoma flabellare

Etheostoma flabellare

Etheostoma osburni

Exoglossum laurae

Hypentelium nigricans

Lepomis cyanellus

Nocomis platyrhynchus

Notropis telescopus

Phoxinus oreas

\begin{tabular}{|c|c|c|c|c|c|c|c|c|c|c|}
\hline A & 120 & 100 & 110 & 8.7 & 144 & 102 & $0.52(0.06)$ & $0.42(0.12)$ & $0.42(0.12)$ & $0.42(0.12)$ \\
\hline $\mathrm{J}$ & 48 & 34 & - & - & - & - & - & - & - & - \\
\hline A & 233 & 208 & 346 & 110.1 & 756 & 243 & $0.29(0.10)$ & $0.18(0.10)$ & $0.18(0.10)$ & $0.18(0.10)$ \\
\hline $\mathrm{J}$ & 7 & 1 & - & - & - & - & - & - & - & - \\
\hline A & 10 & 9 & - & - & - & - & - & - & - & - \\
\hline $\mathrm{J}$ & 1 & 0 & - & - & - & - & - & - & - & - \\
\hline $\mathrm{J}$ & 2 & 2 & - & - & - & - & - & - & - & - \\
\hline A & 22 & 15 & - & - & - & - & - & - & - & - \\
\hline A & 47 & 37 & - & - & - & - & - & - & - & - \\
\hline A & 7 & 7 & - & - & - & - & - & - & - & - \\
\hline A & 1 & 1 & - & - & - & - & - & - & - & - \\
\hline A & 19 & 19 & - & - & - & - & - & - & - & - \\
\hline $\mathrm{J}$ & 5 & 5 & - & - & - & - & - & - & - & - \\
\hline A & 14 & 12 & - & - & - & - & - & - & - & - \\
\hline $\mathrm{J}$ & 5 & 5 & - & - & - & - & - & - & - & - \\
\hline A & 126 & 104 & 110 & 5.0 & 128 & 105 & $0.26(0.04)$ & $0.55(0.07)$ & 0.55 & 0.55 \\
\hline $\mathrm{J}$ & 46 & 34 & - & - & - & - & - & - & - & - \\
\hline A & 321 & 282 & 292 & 5.4 & 309 & 286 & $0.51(0.03)$ & $0.58(0.05)$ & $0.58(0.05)$ & $0.58(0.05)$ \\
\hline $\mathrm{J}$ & 57 & $53 *$ & - & - & - & - & - & - & - & - \\
\hline A & 5 & 4 & - & - & - & - & - & - & - & - \\
\hline A & 1 & 1 & - & - & - & - & - & - & - & - \\
\hline $\mathrm{J}$ & 4 & 3 & - & - & - & - & - & - & - & - \\
\hline $\mathrm{J}$ & 2 & 2 & - & - & - & - & - & - & - & - \\
\hline A & 10 & 10 & - & - & - & - & - & - & - & - \\
\hline A & 28 & 28 & - & - & - & - & - & - & - & - \\
\hline$A$ & 35 & 34 & - & - & - & - & - & - & - & - \\
\hline
\end{tabular}


Appendix 2. continued.

\begin{tabular}{|c|c|c|c|c|c|c|c|c|c|c|c|}
\hline Rhinichthys obtusus & A & 100 & 98 & 98 & 1.3 & 107 & 98 & $0.73(0.05)$ & $0.69(0.10)$ & $0.69(0.10)$ & $0.69(0.10)$ \\
\hline Rhinichthys obtusus & $\mathrm{J}$ & 18 & 18 & - & - & - & - & - & - & - & - \\
\hline Rhinichthys cataractae & A & 4 & 3 & - & - & - & - & - & - & - & - \\
\hline Semotilus atromaculatus & A & 1 & 1 & - & - & - & - & - & - & - & - \\
\hline Semotilus atromaculatus & $\mathrm{J}$ & 2 & 2 & - & - & - & - & - & - & - & - \\
\hline
\end{tabular}

Segment 4 (West Fork)

\section{Backpack}

\begin{tabular}{|c|c|c|c|c|c|c|c|c|c|c|c|}
\hline Cottus bairdi & A & 54 & 46 & 49 & 4.6 & 46 & 72 & $0.61(0.09)$ & $0.43(0.18)$ & $0.43(0.18)$ & $0.43(0.18)$ \\
\hline Cottus bairdi & $\mathrm{J}$ & 2 & 2 & - & - & - & - & - & - & - & - \\
\hline Etheostoma flabellare & A & 83 & 71 & 135 & 97.1 & 617 & 78 & $0.24(0.18)$ & $0.15(0.16)$ & $0.15(0.16)$ & $0.15(0.16)$ \\
\hline Etheostoma flabellare & $\mathrm{J}$ & 1 & 1 & - & - & - & - & - & - & - & - \\
\hline Etheostoma osburni & A & 6 & 6 & - & - & - & - & - & - & - & - \\
\hline Nocomis platyrhynchus & $\mathrm{A}$ & 1 & 0 & - & - & - & - & - & - & - & - \\
\hline Rhinichthys obtusus & A & 31 & 28 & - & - & - & - & - & - & - & - \\
\hline Rhinichthys obtusus & $\mathrm{J}$ & 1 & 1 & - & - & - & - & - & - & - & - \\
\hline Rhinichthys cataractae & A & 5 & 4 & - & - & - & - & - & - & - & - \\
\hline Salmo trutta & $\mathrm{A}$ & 1 & 1 & - & - & - & - & - & - & - & - \\
\hline Salmo trutta & $\mathrm{J}$ & 1 & 1 & - & - & - & - & - & - & - & - \\
\hline Semotilus atromaculatus & $\mathrm{J}$ & 3 & 2 & - & - & - & - & - & - & - & - \\
\hline \multicolumn{12}{|l|}{ Parallel Wires } \\
\hline Cottus bairdi & A & 62 & 58 & 59 & 2.2 & 70 & 58 & $0.57(0.07)$ & $0.59(0.12)$ & $0.59(0.12)$ & $0.59(0.12)$ \\
\hline Cottus bairdi & $\mathrm{J}$ & 5 & 3 & - & - & - & - & - & - & - & - \\
\hline Etheostoma flabellare & A & 222 & 212 & 212 & 0.0 & 212 & 212 & $0.82(0.03)$ & $0.86(0.05)$ & $0.86(0.05)$ & $0.86(0.05)$ \\
\hline Etheostoma flabellare & $\mathrm{J}$ & 6 & 6 & - & - & - & - & - & - & - & - \\
\hline Notropis telescopus & A & 1 & 1 & - & - & - & - & - & - & - & - \\
\hline Phoxinus oreas & $\mathrm{A}$ & 1 & 1 & - & - & - & - & - & - & - & - \\
\hline Rhinichthys obtusus & A & 67 & 66 & 65 & 0.0 & 65 & 65 & $0.94(0.03)$ & $1.00(0.00)$ & $1.00(0.00)$ & $1.00(0.00)$ \\
\hline Rhinichthys obtusus & $\mathrm{J}$ & 3 & 2 & - & - & - & - & - & - & - & - \\
\hline Semotilus atromaculatus & $\mathrm{J}$ & 1 & 0 & - & - & - & - & - & - & - & - \\
\hline
\end{tabular}

Segment 5 (East Fork)

\section{Backpack}

\begin{tabular}{|c|c|c|c|c|c|c|c|c|c|c|c|}
\hline Campostoma anomalum & $\mathrm{A}$ & 188 & 184 & 187 & 5.6 & 216 & 184 & $0.78(0.04)$ & $0.54(0.11)$ & $0.54(0.24)$ & $0.54(0.24)$ \\
\hline Campostoma anomalum & $\mathrm{J}$ & 66 & 63 & 63 & 2.0 & 77 & 63 & $0.71(0.06)$ & $0.60(0.13)$ & $0.66(0.29)$ & $0.66(0.29)$ \\
\hline Clinostomus funduloides & $\mathrm{A}$ & 1 & 1 & - & - & - & - & - & - & - & - \\
\hline Cottus bairdi & A & 96 & 85 & 87 & 4.0 & 109 & 85 & $0.62(0.06)$ & $0.55(0.11)$ & $0.59(0.24)$ & $0.59(0.24)$ \\
\hline Cottus bairdi & $\mathrm{J}$ & 103 & $90^{*}$ & - & - & - & - & - & - & - & - \\
\hline Ehteostoma blennioides & A & 1 & 1 & - & - & - & - & - & - & - & - \\
\hline Etheostoma flabellare & A & 213 & 201 & 223 & 24.8 & 330 & 205 & $0.57(0.07)$ & $0.40(0.07)$ & $0.37(0.20)$ & $0.37(0.20)$ \\
\hline Etheostoma flabellare & $\mathrm{J}$ & 9 & 8 & - & - & - & - & - & - & - & - \\
\hline Etheostoma osburni & A & 16 & 14 & - & - & - & - & - & - & - & - \\
\hline Etheostoma osburni & $\mathrm{J}$ & 1 & 1 & - & - & - & - & - & - & - & - \\
\hline Hypentelium nigricans & $\mathrm{J}$ & 1 & 1 & - & - & - & - & - & - & - & - \\
\hline
\end{tabular}


Appendix 2. continued.

\begin{tabular}{|c|c|c|c|c|c|c|c|c|c|c|c|}
\hline Nocomis platyrhynchus & A & 3 & 3 & - & - & - & - & - & - & - & - \\
\hline Nocomis platyrhynchus & $\mathrm{J}$ & 21 & 21 & - & - & - & - & - & - & - & - \\
\hline Notropis rubellus & $\mathrm{A}$ & 35 & 35 & - & - & - & - & - & - & - & - \\
\hline Notropis rubellus & $\mathrm{J}$ & 1 & 1 & - & - & - & - & - & - & - & - \\
\hline Notropis scabriceps & A & 9 & 9 & - & - & - & - & - & - & - & - \\
\hline Notropis telescopus & A & 22 & 21 & - & - & - & - & - & - & - & - \\
\hline Notropis telescopus & $\mathrm{J}$ & 16 & 16 & - & - & - & - & - & - & - & - \\
\hline Phenacobius teretulus & A & 9 & 9 & - & - & - & - & - & - & - & - \\
\hline Phenacobius teretulus & $\mathrm{J}$ & 2 & 2 & - & - & - & - & - & - & - & - \\
\hline Phoxinus oreas & A & 58 & 57 & 63 & 2.0 & 77 & 63 & $0.58(0.07)$ & $0.63(0.10)$ & $0.82(0.12)$ & $0.82(0.12)$ \\
\hline Phoxinus oreas & $\mathrm{J}$ & 14 & 12 & - & - & - & - & - & - & - & - \\
\hline Rhinichthys cataractae & A & 20 & 18 & - & - & - & - & - & - & - & - \\
\hline Rhinichthys cataractae & $\mathrm{J}$ & 2 & 2 & - & - & - & - & - & - & - & - \\
\hline Rhinichthys obtusus & A & 58 & 58 & 58 & 0.0 & 58 & 58 & $0.66(0.06)$ & $0.70(0.10)$ & 0.86 & $0.86(0.13)$ \\
\hline Rhinichthys obtusus & $\mathrm{J}$ & 22 & 20 & - & - & - & - & - & - & - & - \\
\hline Salmo trutta & $\mathrm{J}$ & 12 & 11 & - & - & - & - & - & - & - & - \\
\hline \multicolumn{12}{|l|}{ Parallel Wires } \\
\hline Campostoma anomalum & A & 155 & 150 & 153 & 5.8 & 182 & 150 & $0.82(0.04)$ & $0.35(0.11)$ & $0.54(0.24)$ & $0.54(0.24)$ \\
\hline Campostoma anomalum & $\mathrm{J}$ & 60 & $50^{*}$ & - & - & - & - & - & - & - & - \\
\hline Cottus bairdi & A & 67 & $63^{*}$ & - & - & - & - & - & - & - & - \\
\hline Cottus bairdi & $\mathrm{J}$ & 49 & $44^{*}$ & - & - & - & - & - & - & - & - \\
\hline Ehteostoma blennioides & $\mathrm{A}$ & 1 & 1 & - & - & - & - & - & - & - & - \\
\hline Etheostoma flabellare & A & 160 & 152 & 180 & 37.2 & 354 & 156 & $0.51(0.11)$ & $0.35(0.15)$ & 0.30 & $0.30(0.23)$ \\
\hline Etheostoma flabellare & $\mathrm{J}$ & 8 & 8 & - & - & - & - & - & - & - & - \\
\hline Etheostoma osburni & A & 17 & 17 & - & - & - & - & - & - & - & - \\
\hline Exoglossum laurae & A & 4 & 4 & - & - & - & - & - & - & - & - \\
\hline Exoglossum laurae & $\mathrm{J}$ & 8 & 8 & - & - & - & - & - & - & - & - \\
\hline Hypentelium nigricans & $\mathrm{J}$ & 1 & 1 & - & - & - & - & - & - & - & - \\
\hline Nocomis platyrhynchus & A & 5 & 5 & - & - & - & - & - & - & - & - \\
\hline Nocomis platyrhynchus & $\mathrm{J}$ & 39 & 38 & - & - & - & - & - & - & - & - \\
\hline Notropis rubellus & A & 5 & 5 & - & - & - & - & - & - & - & - \\
\hline Notropis scabriceps & A & 8 & 8 & - & - & - & - & - & - & - & - \\
\hline Notropis telescopus & A & 13 & 13 & - & - & - & - & - & - & - & - \\
\hline Notropis telescopus & $\mathrm{J}$ & 6 & 6 & - & - & - & - & - & - & - & - \\
\hline Phenacobius teretulus & A & 2 & 2 & - & - & - & - & - & - & - & - \\
\hline Phenacobius teretulus & $\mathrm{J}$ & 1 & 1 & - & - & - & - & - & - & - & - \\
\hline Phoxinus oreas & A & 135 & 131 & 131 & 0.0 & 131 & 131 & $0.86(0.03)$ & $0.79(0.09)$ & $0.80(0.18)$ & $0.80(0.18)$ \\
\hline Phoxinus oreas & $\mathrm{J}$ & 29 & 27 & - & - & - & - & - & - & - & - \\
\hline Rhinichthys cataractae & A & 16 & 16 & - & - & - & - & - & - & - & - \\
\hline Rhinichthys cataractae & $\mathrm{J}$ & 5 & 4 & - & - & - & - & - & - & - & - \\
\hline Rhinichthys obtusus & A & 88 & 85 & 84 & 1.6 & 95 & 84 & $0.80(0.05)$ & $0.53(0.13)$ & $0.71(0.25)$ & $0.71(0.25)$ \\
\hline Rhinichthys obtusus & $\mathrm{J}$ & 34 & 33 & - & - & - & - & - & - & - & - \\
\hline Salmo trutta & $\mathrm{J}$ & 2 & 2 & - & - & - & - & - & - & - & - \\
\hline Salvelinus fontinalis & $\mathrm{J}$ & 1 & 1 & - & - & - & - & - & - & - & - \\
\hline
\end{tabular}


Appendix 2. continued.

Segment 6 (Little River of East Fork)

\section{Backpack}

\begin{tabular}{|c|c|c|c|c|c|c|c|c|c|c|c|}
\hline Campostoma anomalum & A & 15 & 15 & - & - & - & - & - & - & - & - \\
\hline Campostoma anomalum & $\mathrm{J}$ & 3 & 3 & - & - & - & - & - & - & - & - \\
\hline Cottus bairdi & $\mathrm{A}$ & 90 & $71^{*}$ & - & - & - & - & - & - & - & - \\
\hline Cottus bairdi & $\mathrm{J}$ & 58 & 38 & - & - & - & - & - & - & - & - \\
\hline Etheostoma flabellare & A & 197 & $152^{*}$ & - & - & - & - & - & - & - & - \\
\hline Etheostoma flabellare & $\mathrm{J}$ & 38 & 26 & - & - & - & - & - & - & - & - \\
\hline Etheostoma osburni & $\mathrm{A}$ & 9 & 9 & - & - & - & - & - & - & - & - \\
\hline Etheostoma osburni & $\mathrm{J}$ & 2 & 2 & - & - & - & - & - & - & - & - \\
\hline Exoglossum laurae & A & 1 & 1 & - & - & - & - & - & - & - & - \\
\hline Micropterus salmoides & $\mathrm{J}$ & 2 & 1 & - & - & - & - & - & - & - & - \\
\hline Phoxinus oreas & $\mathrm{A}$ & 13 & 12 & - & - & - & - & - & - & - & - \\
\hline Phoxinus oreas & $\mathrm{J}$ & 4 & 4 & - & - & - & - & - & - & - & - \\
\hline Rhinichthys obtusus & $\mathrm{A}$ & 82 & 78 & 78 & 1.6 & 89 & 78 & $0.52(0.06)$ & $0.59(0.08)$ & $0.76(0.16)$ & $0.76(0.16)$ \\
\hline Rhinichthys obtusus & $\mathrm{J}$ & 10 & 8 & - & - & - & - & - & - & - & - \\
\hline Rhinichthys cataractae & $\mathrm{A}$ & 3 & 3 & - & - & - & - & - & - & - & - \\
\hline Salmo trutta & $\mathrm{J}$ & 2 & 2 & - & - & - & - & - & - & - & - \\
\hline \multicolumn{12}{|l|}{ Parallel Wires } \\
\hline Campostoma anomalum & A & 15 & 15 & - & - & - & - & - & - & - & - \\
\hline Campostoma anomalum & $\mathrm{J}$ & 3 & 2 & - & - & - & - & - & - & - & - \\
\hline Cottus bairdi & $\mathrm{A}$ & 112 & 87 & 91 & 4.8 & 113 & 86 & $0.44(0.08)$ & $0.44(0.06)$ & $0.62(0.17)$ & $0.62(0.17)$ \\
\hline Cottus bairdi & $\mathrm{J}$ & 49 & 36 & - & - & - & - & - & - & - & - \\
\hline Etheostoma flabellare & A & 255 & 221 & 252 & 26.7 & 354 & 228 & $0.50(0.06)$ & $0.29(0.07)$ & $0.41(0.16)$ & $0.41(0.16)$ \\
\hline Etheostoma flabellare & $\mathrm{J}$ & 29 & 19 & - & - & - & - & - & - & - & - \\
\hline Etheostoma osburni & $\mathrm{A}$ & 4 & 3 & - & - & - & - & - & - & - & - \\
\hline Etheostoma osburni & $\mathrm{J}$ & 2 & 2 & - & - & - & - & - & - & - & - \\
\hline Lepomis auritus & A & 1 & 1 & - & - & - & - & - & - & - & - \\
\hline Phoxinus oreas & A & 12 & 12 & - & - & - & - & - & - & - & - \\
\hline Rhinichthys obtusus & $\mathrm{A}$ & 64 & 60 & 60 & 0.0 & 60 & 60 & $0.67(0.06)$ & $0.55(0.11)$ & $0.9(0.09)$ & $0.9(0.09)$ \\
\hline Rhinichthys obtusus & $\mathrm{J}$ & 7 & 7 & - & - & - & - & - & - & - & - \\
\hline Salmo trutta & $\mathrm{J}$ & 1 & 1 & & & & & & & & \\
\hline Salvelinus fontinalis & $\mathrm{J}$ & 1 & 1 & - & - & - & - & - & - & - & - \\
\hline
\end{tabular}

Segment 7 (East Fork)

\section{Backpack}

Campostoma anomalum

Cottus bairdi

Cottus bairdi

Etheostoma flabellare

Etheostoma flabellare

Etheostoma osburni

Phoxinus oreas

$\begin{array}{ccccccccccc}\mathrm{A} & 13 & 13 & - & - & - & - & - & - & - & - \\ \mathrm{A} & 153 & 134 & 144 & 6.8 & 167 & 137 & 0.42(0.05) & 0.50(0.08) & 0.50(0.08) & 0.50(0.08) \\ \mathrm{J} & 63 & 51 & 73 & 26.9 & 194 & 54 & 0.27(0.11) & 0.25(0.16) & 0.25(0.16) & 0.25(0.16) \\ \mathrm{A} & 128 & 108 & 125 & 12.9 & 172 & 113 & 0.42(0.06) & 0.38(0.11) & 0.38(0.11) & 0.38(0.11) \\ \mathrm{J} & 7 & 6 & - & - & - & - & - & - & - & - \\ \mathrm{A} & 1 & 1 & - & - & - & - & - & - & - & - \\ \mathrm{A} & 1 & 1 & - & - & - & - & - & - & - & -\end{array}$


Appendix 2. continued.

\begin{tabular}{|c|c|c|c|c|c|c|c|c|c|c|c|}
\hline Rhinichthys cataractae & A & 8 & 7 & - & - & - & - & - & - & - & - \\
\hline Rhinichthys obtusus & A & 56 & 53 & 55 & 2.7 & 68 & 53 & $0.57(0.07) 0$ & $0.55(0.14)$ & $0.55(0.14)$ & $0.55(0.14)$ \\
\hline Rhinichthys obtusus & $\mathrm{J}$ & 10 & 6 & - & - & - & - & - & - & - & - \\
\hline Salmo trutta & A & 4 & 3 & - & - & - & - & - & - & - & - \\
\hline Salmo trutta & $\mathrm{J}$ & 15 & 15 & - & - & - & - & - & - & - & - \\
\hline Salvelinus fontinalis & A & 1 & 1 & - & - & - & - & - & - & - & - \\
\hline Salvelinus fontinalis & $\mathrm{J}$ & 2 & 2 & - & - & - & - & - & - & - & - \\
\hline \multicolumn{12}{|l|}{ Parallel Wires } \\
\hline Campostoma anomalum & A & 21 & 21 & - & - & - & - & - & - & - & - \\
\hline Campostoma anomalum & $\mathrm{J}$ & 1 & 1 & - & - & - & - & - & - & - & - \\
\hline Cottus bairdi & A & 136 & 120 & 137 & 11.4 & 176 & 125 & $0.40(0.05) 0$ & $11(0.10)$ & $0.41(0.10)$ & $0.41(0.10)$ \\
\hline Cottus bairdi & $\mathrm{J}$ & 80 & $67^{*}$ & - & - & - & - & - & - & - & - \\
\hline Etheostoma flabellare & A & 147 & 138 & 143 & 4.2 & 159 & 139 & $0.53(0.04) 0$ & $0.56(0.08)$ & $0.56(0.08)$ & $0.56(0.08)$ \\
\hline Etheostoma flabellare & $\mathrm{J}$ & 16 & 15 & - & - & - & - & - & - & - & - \\
\hline Etheostoma osburni & A & 1 & 1 & - & - & - & - & - & - & - & - \\
\hline Phoxinus oreas & A & 5 & 5 & - & - & - & - & - & - & - & - \\
\hline Rhinichthys cataractae & A & 8 & 7 & - & - & - & - & - & - & - & - \\
\hline Rhinichthys cataractae & $\mathrm{J}$ & 1 & 1 & - & - & - & - & - & - & - & - \\
\hline Rhinichthys obtusus & A & 50 & 46 & 46 & 0.0 & 46 & 46 & $0.78(0.06) 0$ & $0.67(0.12)$ & $0.67(0.12)$ & $0.67(0.12)$ \\
\hline Rhinichthys obtusus & $\mathrm{J}$ & 3 & 3 & - & - & - & - & - & - & - & - \\
\hline Salmo trutta & $\mathrm{J}$ & 9 & 9 & - & - & - & - & - & - & - & - \\
\hline Salvelinus fontinalis & $\mathrm{J}$ & 2 & 2 & - & - & - & - & - & - & - & - \\
\hline
\end{tabular}

Segment 8 (East Fork)

\section{Backpack}

\begin{tabular}{|c|c|c|c|c|c|c|c|c|c|c|c|}
\hline Campostoma anomalum & A & 2 & 1 & - & - & - & - & - & - & - & - \\
\hline Cottus bairdi & A & 95 & 77 & 81 & 5.9 & 109 & 78 & $0.44(0.06)$ & $0.40(0.09)$ & 0.40 & $0.40(0.09)$ \\
\hline Cottus bairdi & $\mathrm{J}$ & 20 & 16 & - & - & - & - & - & - & - & - \\
\hline Etheostoma flabellare & A & 66 & $56^{*}$ & - & - & - & - & - & - & - & - \\
\hline Etheostoma flabellare & $\mathrm{J}$ & 4 & 3 & - & - & - & - & - & - & - & - \\
\hline Etheostoma osburni & A & 1 & 1 & - & - & - & - & - & - & - & - \\
\hline Rhinichthys cataractae & A & 6 & 6 & - & - & - & - & - & - & - & - \\
\hline Rhinichthys cataractae & $\mathrm{J}$ & 3 & 2 & - & - & - & - & - & - & - & - \\
\hline Rhinichthys obtusus & A & 20 & 16 & - & - & - & - & - & - & - & - \\
\hline Rhinichthys obtusus & $\mathrm{J}$ & 2 & 2 & - & - & - & - & - & - & - & - \\
\hline Salmo trutta & A & 11 & 11 & - & - & - & - & - & - & - & - \\
\hline Salmo trutta & $\mathrm{J}$ & 5 & 4 & - & - & - & - & - & - & - & - \\
\hline \multicolumn{12}{|l|}{ Parallel Wires } \\
\hline Campostoma anomalum & A & 1 & 1 & - & - & - & - & - & - & - & - \\
\hline Cottus bairdi & A & 94 & 83 & 94 & 16.2 & 173 & 84 & $0.49(0.10)$ & $0.35(0.14)$ & $0.39(0.25)$ & $0.39(0.25)$ \\
\hline Cottus bairdi & $\mathrm{J}$ & 76 & $63^{*}$ & - & - & - & - & - & - & - & - \\
\hline Etheostoma flabellare & A & 105 & $94 *$ & - & - & - & - & - & - & - & - \\
\hline Etheostoma flabellare & $\mathrm{J}$ & 11 & 9 & - & - & - & - & - & - & - & - \\
\hline Rhinichthys cataractae & A & 9 & 7 & - & - & - & - & - & - & - & - \\
\hline
\end{tabular}


Appendix 2. continued

Rhinichthys cataractae

Rhinichthys obtusus

Salmo trutta

Salmo trutta

Salvelinus fontinalis

$\begin{array}{ccccccccccc}\mathrm{J} & 1 & 1 & - & - & - & - & - & - & - & - \\ \mathrm{A} & 61 & 57 & 57 & 0.0 & 57 & 57 & 0.79(0.05) & 0.83(0.11) & 1.00(0.00) & 1.00(0.00) \\ \mathrm{A} & 3 & 3 & - & - & - & - & - & - & - & - \\ \mathrm{J} & 4 & 2 & - & - & - & - & - & - & - & - \\ \mathrm{A} & 1 & 1 & - & - & - & - & - & - & - & -\end{array}$

Segment 9 (East Fork)

Backpack

Campostoma anomalum

$\begin{array}{ccccccccccc}\mathrm{A} & 11 & 10 & - & - & - & - & - & - & - & - \\ \mathrm{J} & 1 & 1 & - & - & - & - & - & - & - & - \\ \mathrm{A} & 85 & 70 & 72 & 2.9 & 85 & 70 & 0.47(0.06) & 0.58(0.10) & 0.58(0.10) & 0.58(0.10) \\ \mathrm{J} & 39 & 25 & - & - & - & - & - & - & - & -\end{array}$

Campostoma anomalum

Cottus bairdi

Cottus bairdi

Etheostoma flabellare

Etheostoma flabellare

Exoglossum laurae

Notropis rubellus

Phoxinus oreas

Rhinichthys cataractae

Rhinichthys cataractae

Rhinichthys obtusus

Salmo trutta

Salmo trutta

Salvelinus fontinalis

Parallel Wires

Campostoma anomalum

Cottus bairdi

Cottus bairdi

Etheostoma flabellare

Hypentelium nigricans

Oncorhynchus mykiss

Phoxinus oreas

Rhinichthys cataractae

Rhinichthys obtusus

Salmo trutta

Salmo trutta

Salvelinus fontinalis

Salvelinus fontinalis

$$
\begin{array}{lllllllll}
\text { A } & 91 & 70 & 70 & 0.0 & 70 & 70 & 0.60(0.06) 0.74(0.07) & 0.74(0.07) 0.74(0.07)
\end{array}
$$

J 4

A

A

A 4

A 4

$\mathrm{J}$

A 73

A 4

J 4

6

1

- $-\quad-\quad-\quad-$

$-\quad-\quad-$

$-\quad-\quad-\quad-$

$-\quad-\quad-\quad-$

$67 \quad 4.0 \quad 85$

J

4
4
1

$-$

$-$

$\begin{array}{cccccccc}\mathrm{A} & 21 & 20 & - & - & - & - & - \\ \mathrm{A} & 83 & 62^{*} & - & - & - & - & - \\ \mathrm{J} & 31 & 26 & - & - & - & - & - \\ \mathrm{A} & 108 & 96^{*} & - & - & - & - & - \\ \mathrm{A} & 1 & 1 & - & - & - & - & - \\ \mathrm{A} & 1 & 1 & - & - & - & - & - \\ \mathrm{A} & 2 & 2 & - & - & - & - & - \\ \mathrm{A} & 4 & 3 & - & - & - & - & - \\ \mathrm{A} & 49 & 45^{*} & - & - & - & - & - \\ \mathrm{A} & 5 & 5 & - & - & - & - & - \\ \mathrm{J} & 8 & 7 & - & - & - & - & - \\ \mathrm{A} & 1 & 1 & - & - & - & - & - \\ \mathrm{J} & 1 & 1 & - & - & - & - & -\end{array}$

Segment 10 (Long Run)

\section{Backpack}

Cottus bairdi

A 124

116

$120 \quad 5.8 \quad 147$

Cottus bairdi

Etheostoma flabellare

Salmo trutta

$\begin{array}{cccccccc}\mathrm{J} & 11 & 9 & - & - & - & - & - \\ \mathrm{A} & 38 & 34 & - & - & - & - & - \\ \mathrm{J} & 13 & 13 & - & - & - & - & -\end{array}$


Appendix 2. continued.

Salvelinus fontinalis

Parallel Wires

Rhinichthys obtusus

Rhinichthys cataractae

Cottus bairdi

Cottus bairdi

Etheostoma flabellare

Salmo trutta

Salvelinus fontinalis
$\begin{array}{llllllllllll}\mathrm{J} & 4 & 3 & - & - & - & - & - & - & -\end{array}$

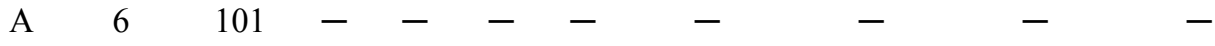

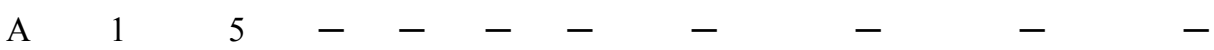

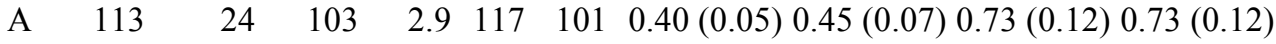

$\begin{array}{lllllllllll}\mathrm{J} & 5 & 6 & - & - & - & - & - & - & -\end{array}$

$\begin{array}{llllllllllll}\mathrm{A} & 25 & 1 & - & - & - & - & - & - & -\end{array}$

$\begin{array}{lllllllllll} & \mathrm{J} & 7 & 7 & - & - & - & - & - & - & -\end{array}$

$\begin{array}{lllllllllll}\mathrm{J} & 9 & 9 & - & - & - & - & - & - & -\end{array}$ 
Appendix 3. Fish distributions in the Greenbrier River, West Virginia

Sites were sampled in the Greenbrier River drainage in summer and fall of 20052006. Study objective were to estimate abundances of sensitive species, specifically the four New River endemics: candy darter, Kanawha minnow, New River shiner and Appalachia darter. Qualitative and quantitative methods were used in this collection. I sampled fifteen $150 \mathrm{~m}$ sites with three sampling occasions, except one double pass site with a parallel wire unit modified from the Holton and Sullivan (1954) design and described in chapter two of this thesis. Eleven qualitative sites were sampled in locations where stream conditions were to wide to permit extensive sampling or in areas of special interest. Qualitative sites were sampled with a Smith-Root ${ }^{\circledR}$ backpack unit (Model 12B) for a minimum of 15 minutes at each location. Chapter 2 described a comparison study where some sensitive fish species were captured and these sites are included. In this appendix I provide maps and tables of the locations of sensitive fishes captured in this two year study. I also include a table of all fish species captured at the $150 \mathrm{~m}$ sites. I list population estimates, standard errors, $95 \%$ confidence intervals and capture probabilities for fish species and age classes with $>40$ individuals captured. Total number captured is listed for all species with $<40$ individuals. 


\section{0 meter sites}

A1 West Fork

A2 Knapp Creek

A3 Little River of East Fork

A4 Sitlington Creek

A5 Knapp Creek

A6 Deer Creek

A7 North Fork of Deer Creek

A8 $\quad$ North Fork of Deer Creek

A9 North Fork of Anthony

A10 Anthony Creek

A11 West Fork

A12 East Fork

A13 Anthony Creek

A14 Anthony Creek

A15 Anthony Creek
$0.35 \mathrm{~km} \mathrm{~N}$ of the confluence of Elklick Run and $3 \mathrm{~km} \mathrm{~N}$ May, WV

at Herold farm pasture on Rt 92, approximately $2 \mathrm{~km} \mathrm{~S}$ Frost, WV

on Rt. 250, approximately $1.25 \mathrm{~km}$ E of the $28 / 250$ junction, $2 \mathrm{~km} \mathrm{E}$ Thornwood, WV

on Rt. 92, approximately $2.7 \mathrm{~km} \mathrm{~S}$ of the 92/28 junction in Dunmore, $\quad 599970 \quad 4244535$ WV

on Camp Minnehaha property at Minnehaha Springs, WV

at Rt. 66 bridge approximately $1 \mathrm{~km} \mathrm{E}$ of $66 / 28$ junction, $4 \mathrm{~km} \mathrm{SW}$ Green Bank, WV

at the 28/92 bridge approximately $2 \mathrm{~km} \mathrm{SW}$ of Green Bank, WV

on CR 28-5 bridge on the Clevenger property, Green Bank, WV

approximately $2 \mathrm{~km} \mathrm{~N}$ on FR 96 Neola, WV

approximately $0.5 \mathrm{~km}$ E of Blue Bend, WV on CR 21-2 at iron bridge

approximately $0.2 \mathrm{~km} \mathrm{~N}$ of the Rt. 250 bridge, Durbin, WV

5895534224219

5988724251056

$599901 \quad 4252597$

$602178 \quad 4252594$

$575891 \quad 4204322$

$565067 \quad 4196893$

$602012 \quad 4267972$

approximately $1 \mathrm{~km} \mathrm{~S}$ of Camp Pocahontas (28/PR 14 intersection), 6 $\mathrm{km}$ N Bartow, WV

approximately $3.5 \mathrm{~km}$ E of Blue Bend, WV on CR 21-2

$611322 \quad 4269358$

approximately $3.8 \mathrm{~km}$ E of Blue Bend, WV on CR 21-2

5616534195970

5613124196091

approximately $2.9 \mathrm{~km}$ E of Blue Bend, WV on CR 21-2

$561928 \quad 4195801$ 
Appendix 3.1 continued.

\section{Comparison sites (Chapter 2)}

$1 \quad$ Knapp Creek (UK)

approximately $1.9 \mathrm{~km}$ E of Frost on Rt. 84

599805

4236414

2 Galford Run (GR)

on Melko property on CR 6-2, approximately 0.7 km E of CR 6/CR 6- 603889

4247674

2 junction

Little River of West Fork (LW)

$4 \quad$ West Fork (WF)

N Braucher, WV

approximately $150 \mathrm{~m}$ downstream of A1 (150 meter site)

604046

4274728

$5 \quad$ East Fork (IB)

at the 28-19 bridge, approximately $1.5 \mathrm{~km} \mathrm{~N}$ of Bartow, WV

605303

4280949

on Rt. 250, approximately $0.9 \mathrm{~km}$ E of the $28 / 250$ junction

607920

4267188

Little River of East Fork (LE)

on

East Fork (CT)

downstream of the Rt 28/PR 14 bridge at Camp Pocahontas, $7 \mathrm{~km} \mathrm{~N}$

610664

4267301 Bartow, WV

East Fork (E2)

approximately $0.3 \mathrm{~km} \mathrm{~N}$ of Rt 28/RR 14 Junction at Camp

611789

4270227

Pocahontas, $7.3 \mathrm{~km}$ N Bartow, WV

$9 \quad$ East Fork (E1)

$10 \quad$ Long Run (LO)

approximately $0.6 \mathrm{~km} \mathrm{~N}$ of Rt 28/PR 14 Junction at Camp

611976

4270354

Pocahontas, $7.6 \mathrm{~km}$ N Bartow, WV

appproximately $1.1 \mathrm{~km} \mathrm{~N}$ of Camp Pocahontas upstream of Rt. 28

bridge crossing, $8.3 \mathrm{~km} \mathrm{~N}$ Bartow, WV

$612327 \quad 4270415$

$613035 \quad 4270321$ 
Appendix 3.1 continued.

\section{Qualitative Sampling}

Q1 Anthony Creek

Q2 Greenbrier

Q3 Greenbrier

Q4 Knapp Creek

Q5 Sitlington Creek

Q6 Greenbrier

Q7 West Fork

Q8 Greenbrier

Q9 Greenbrier

Q10 East Fork

Q11 East Fork approximately $300 \mathrm{~m}$ upstream of confluence with Greenbrier River at

559352

Anthony, WV

at confluence with Anthony Creek at Anthony, WV

$559262 \quad 4193847$

approximately $0.5 \mathrm{~km} \mathrm{~N}$ of $219 / 39$ junction, Marlinton, WV

$579331 \quad 4231400$

approximately $5 \mathrm{~km}$ E of Marlinton, WV on Rt. 39

583268

4229506

approximately $200 \mathrm{~m}$ upstream of confluence with the Greenbrier

River

at the Rt. 66 bridge, Cass, WV

at the CR 250-11 bridge, Durbin, WV

approximately $3 \mathrm{~km} \mathrm{~S}$ of Durbin, WV on CR 250-2

approximately $2 \mathrm{~km} \mathrm{~S}$ of Durbin, WV on CR 250-2

at East Fork Campground, Durbin, WV

downstream of 28-19 bridge approximately $1.5 \mathrm{~km} \mathrm{~N}$ of Bartow, WV
$593959 \quad 4246010$

5948324250116

$601818 \quad 4267376$

$601133 \quad 4264505$

$601660 \quad 4265601$

$602368 \quad 4266632$

$607936 \quad 4267191$ 


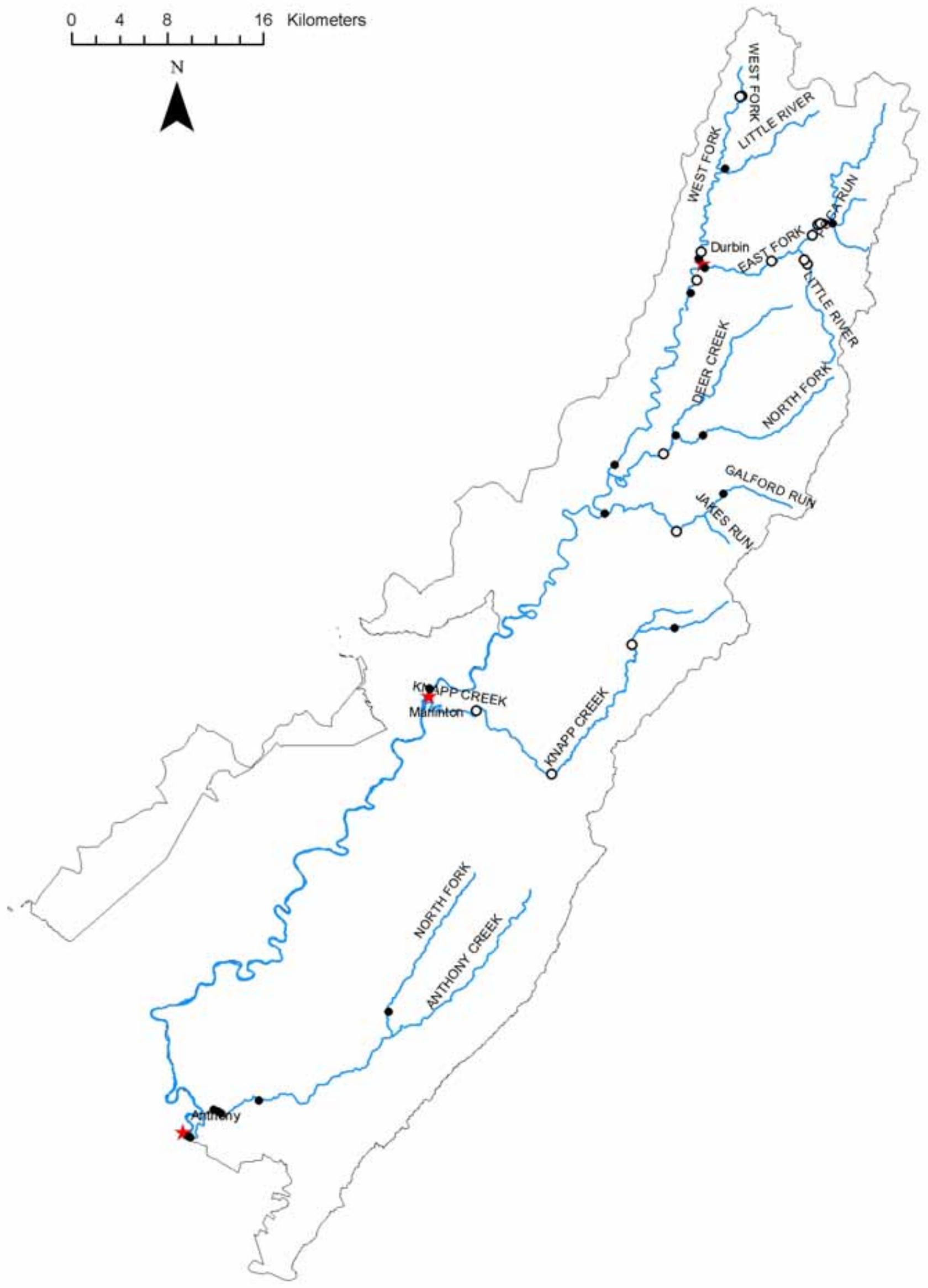

Appendix 3.2 Locations of candy darter captures in 2005-2006 (denoted by open circle). 


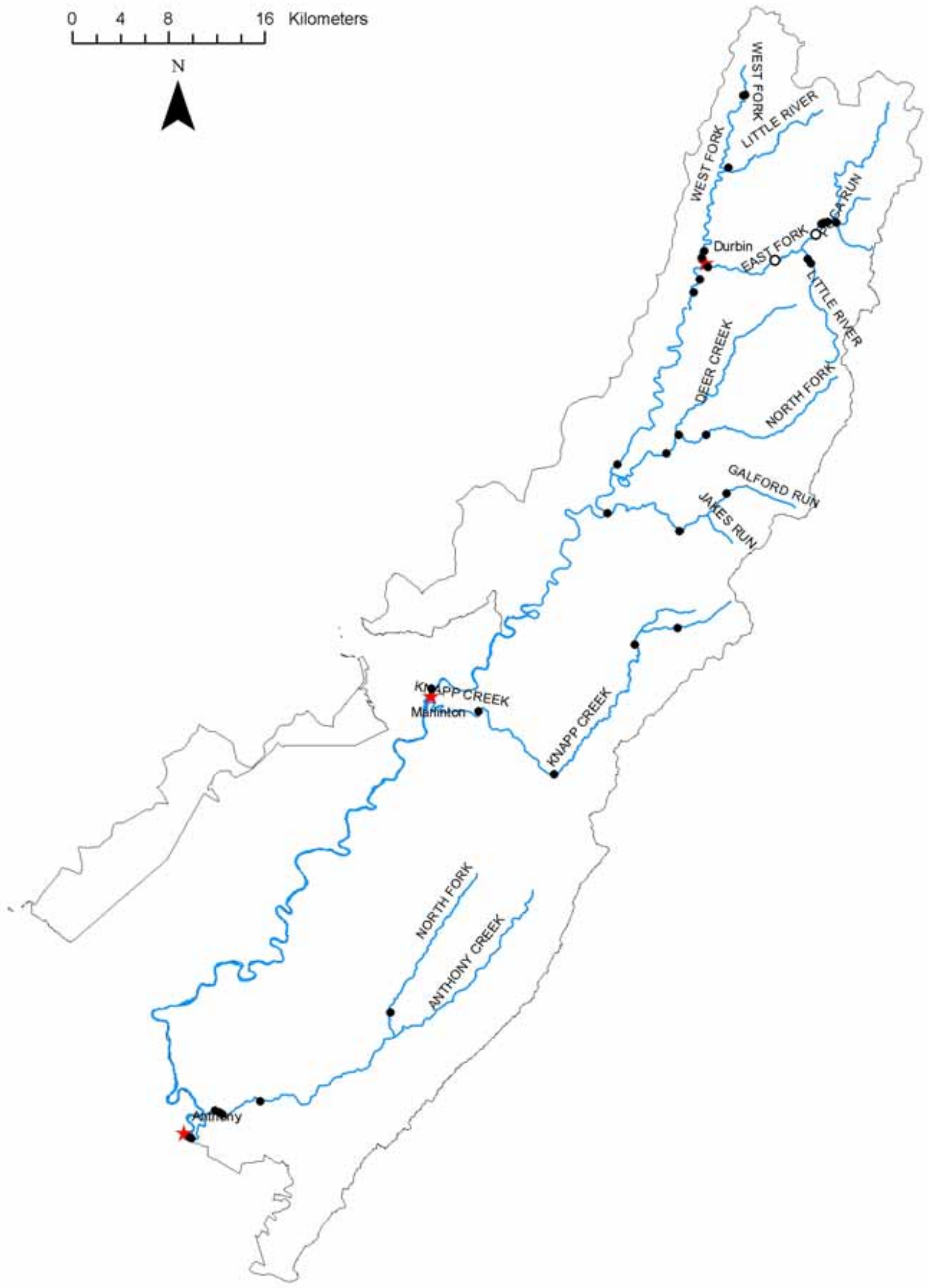

Appendix 3.3 Locations of Kanawha minnow captures in 2005-2006 (denoted by open circle). 


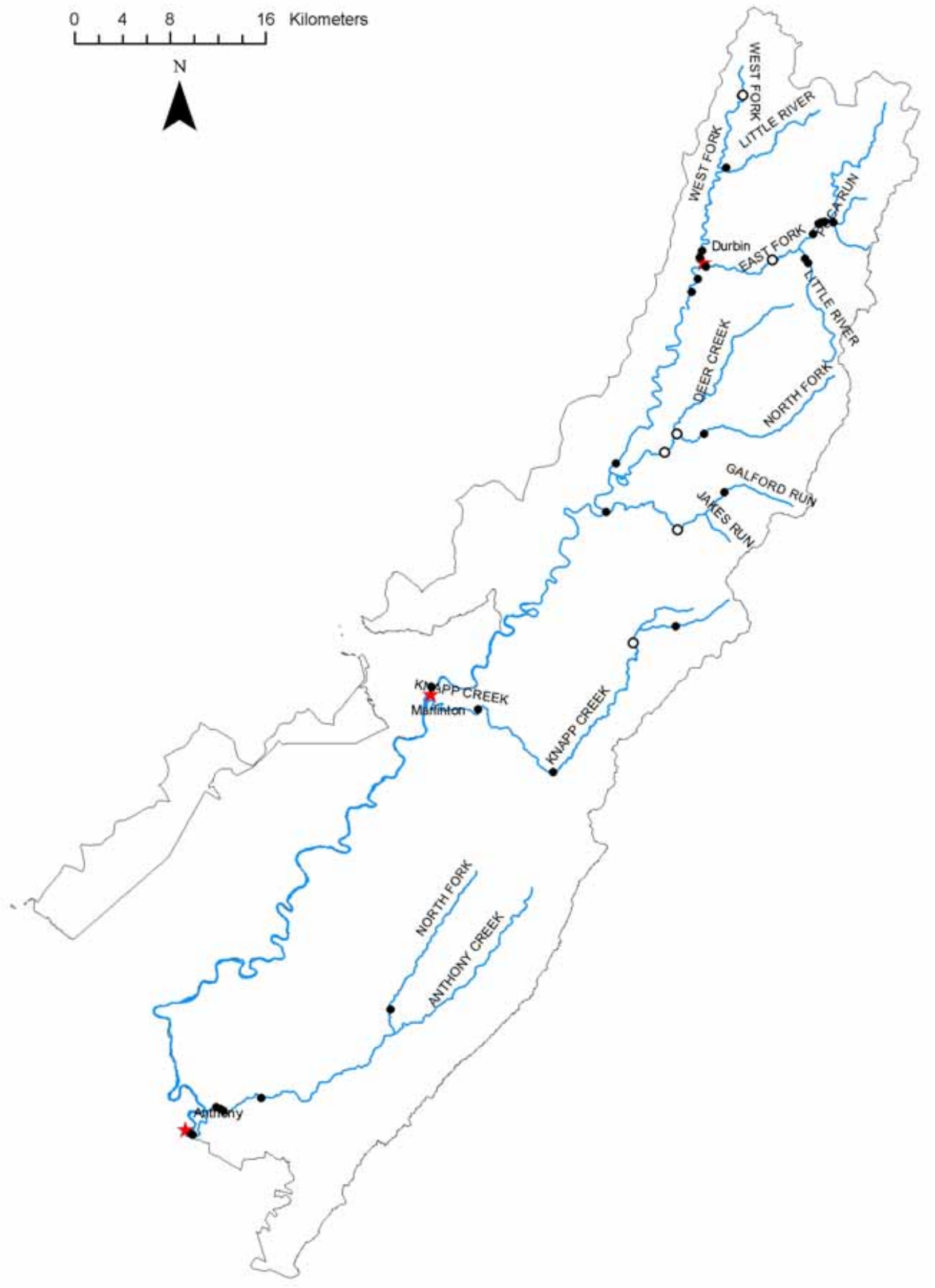

Appendix 3.4 Locations of New River shiner captures in 2005-2006 (denoted by the open circles). 


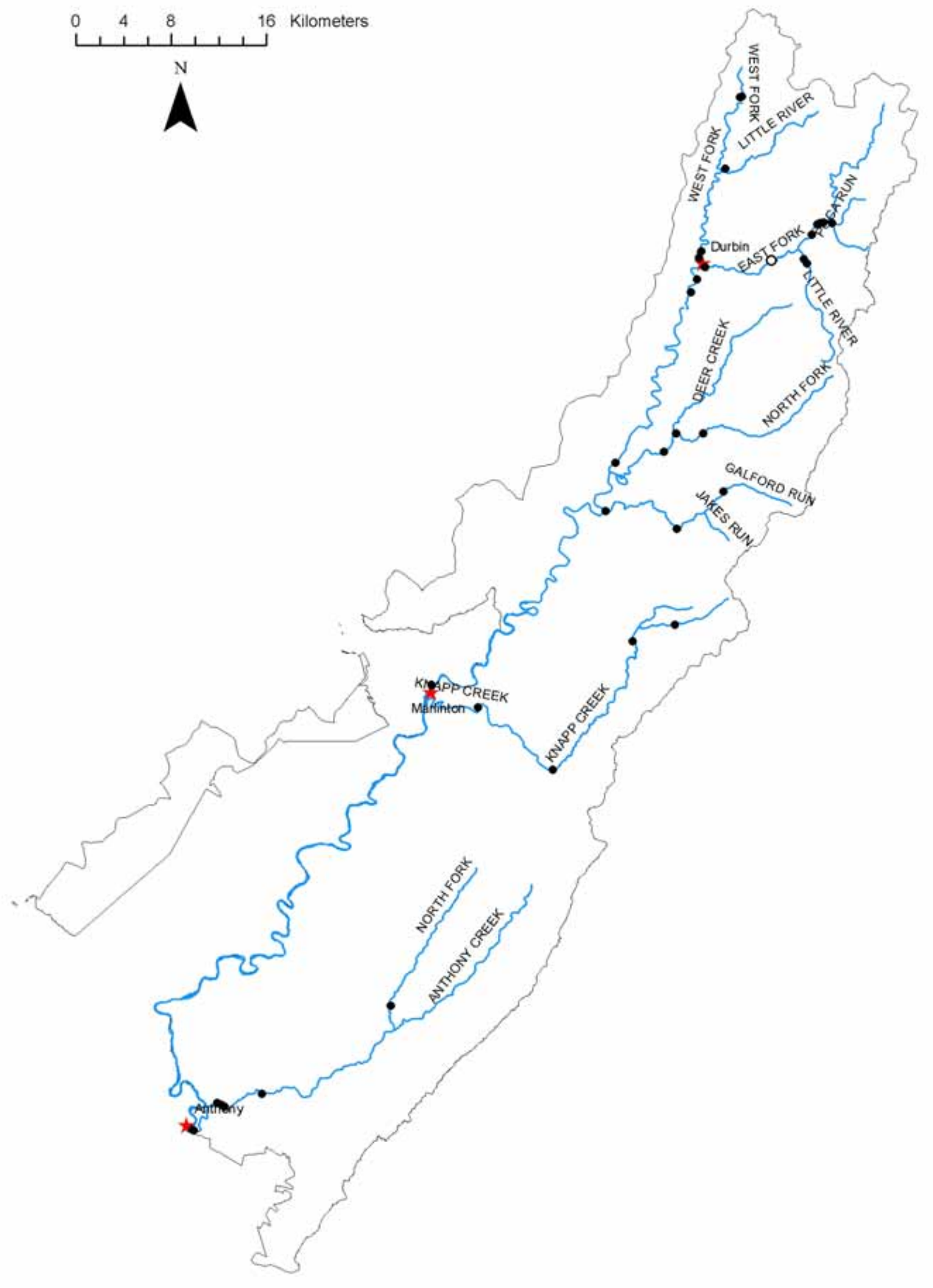

Appendix 3.5 Location of an Appalachia darter capture in 2005-2006 (denoted by the open circle). 
Appendix 3.6 Quantitative and qualitative (P) samples (2005-2006) of candy darter, Kanawha minnow, New River shiner and Appalachia darter.

Candy darter

\begin{tabular}{|clc|}
\hline Site ID & Location & Number Collected \\
\hline \hline A12 & East Fork of the Greenbrier & 2 \\
A6 & Deer Creek & 4 \\
A11 & West Fork & 3 \\
A5 & Knapp Creek & 6 \\
A2 & Knapp Creek & 30 \\
A4 & Sitlington Creek & 20 \\
A3 & Little River of East Fork & 18 \\
A1 & West Fork & 8 \\
LW & Little River of West Fork & 16 \\
WF & West Fork & 6 \\
CT & East Fork & 2 \\
IB & East Fork & 34 \\
E2 & East Fork & 1 \\
LE & Little River of East Fork & 17 \\
Q4 & Knapp Creek & $\mathrm{P}$ \\
Q9 & Greenbrier & $\mathrm{P}$ \\
Q11 & East Fork & $\mathrm{P}$ \\
\hline
\end{tabular}

Kanawha minnow

\begin{tabular}{|llc|}
\hline \multicolumn{1}{|c|}{ Site ID } & Location & Number Collected \\
\hline \hline A12 & East Fork & 1 \\
IB & East Fork & 14 \\
Q11 & East Fork & $\mathrm{P}$ \\
\hline
\end{tabular}

New River shiner

\begin{tabular}{|clc|}
\hline Site ID & Location & Number Collected \\
\hline \hline A7 & North Fork of Deer Creek & 34 \\
A6 & Deer Creek & 27 \\
A2 & Knapp Creek & 177 \\
A4 & Sitlington Creek & 108 \\
A1 & West Fork & 12 \\
IB & East Fork & 17 \\
Q11 & East Fork & $\mathrm{P}$ \\
\hline
\end{tabular}

Appalachia darter

\begin{tabular}{|ccc|}
\hline Site ID & Location & Number Collected \\
\hline \hline Q11 & East Fork & $\mathrm{P}$ \\
\hline
\end{tabular}


Appendix 3.7 Species abundances $(\hat{N})$ and capture probabilities $(\hat{p})$ estimated from three-pass removal studies (with the exception of one two-pass site where total counts are provided) with parallel wire electrofishing gears at 15 sites in the Greenbrier River drainage, West Virginia. Total counts from three sampling occasions are provided for adults (A) and juveniles (J) of each species. Abundance estimates, standard error (SE, parenthetic for $\hat{p}$ ), and lower (LCL) and upper (UCL) 95\% confidence limits are provided when three-pass sample sizes exceed 40 individuals. An asterisk adjacent to a three-pass count indicates failure of removal depletion. Site descriptions are in Appendix 3.1.

\begin{tabular}{|c|c|c|c|c|c|c|c|c|c|}
\hline $\begin{array}{l}\text { Species by stream } \\
\text { segment and gear }\end{array}$ & Age & $\begin{array}{c}\text { Total } \\
\text { 3-pass }\end{array}$ & $\hat{N}$ & SE & LCL & UCL & $\hat{p}_{1}$ & $\hat{p}_{2}$ & $\hat{p}_{3}$ \\
\hline \multicolumn{10}{|l|}{ Site A1 } \\
\hline Ambloplites rupestris & A & 10 & - & - & - & - & - & - & - \\
\hline Ambloplites rupestris & $\mathrm{J}$ & 0 & - & - & - & - & - & - & - \\
\hline Campostoma anomalum & A & 21 & - & - & - & - & - & - & - \\
\hline Campostoma anomalus & $\mathrm{J}$ & 1 & - & - & - & - & - & - & - \\
\hline Cottus bairdi & A & 232 & 380 & 138.8 & 263 & 934 & $0.33(0.12)$ & $0.23(0.15)$ & $0.23(0.15)$ \\
\hline Cottus bairdi & $\mathrm{J}$ & 14 & - & - & - & - & - & - & - \\
\hline Etheostoma blennioides & A & 8 & - & - & - & - & - & - & - \\
\hline Etheostoma blennioides & $\mathrm{J}$ & 0 & - & - & - & - & - & - & - \\
\hline Etheostoma flabellare & A & 583 & 821 & 117.4 & 678 & 1177 & $0.40(0.06)$ & $0.31(0.09)$ & $0.31(0.09)$ \\
\hline Etheostoma flabellare & $\mathrm{J}$ & 13 & - & - & - & - & - & - & - \\
\hline Etheostoma osburni & A & 7 & - & - & - & - & - & - & - \\
\hline Etheostoma osburni & $\mathrm{J}$ & 1 & - & - & - & - & - & - & - \\
\hline Exoglossum laurae & A & 1 & - & - & - & - & - & - & - \\
\hline Exoglossum laurae & $\mathrm{J}$ & 5 & - & - & - & - & - & - & - \\
\hline Hypentelium nigricans & A & 2 & - & - & - & - & - & - & - \\
\hline Hypentelium nigricans & $\mathrm{J}$ & 12 & - & - & - & - & - & - & - \\
\hline Nocomis platyrhnchus & A & 5 & - & - & - & - & - & - & - \\
\hline Notropis scabriceps & A & 9 & - & - & - & - & - & - & - \\
\hline Notropis scabriceps & $\mathrm{J}$ & 3 & - & - & - & - & - & - & - \\
\hline Notropis telescopus & A & $53 *$ & - & - & - & - & - & - & - \\
\hline Phoxinus oreas & A & 11 & - & - & - & - & - & - & - \\
\hline Phoxinus oreas & $\mathrm{J}$ & 0 & - & - & - & - & - & - & - \\
\hline Rhinichthys obtusus & A & 355 & 366 & 7.3 & 358 & 391 & $0.75(0.03)$ & $0.65(0.09)$ & $0.65(0.09)$ \\
\hline Rhinichthys obtusus & $\mathrm{J}$ & 18 & - & - & - & - & - & - & - \\
\hline Salmo trutta & A & 2 & - & - & - & - & - & - & - \\
\hline Semotilus atromaculatus & A & 28 & - & - & - & - & - & - & - \\
\hline Semotilus atromaculatus & $\mathrm{J}$ & 31 & - & - & - & - & - & - & - \\
\hline
\end{tabular}

Site A2

Ambloplites rupestris

Ambloplites rupestris

Campostoma anomalum

Campostoma anomalus

$\begin{array}{ccccccccc}\mathrm{A} & 29 & - & - & - & - & - & - & - \\ \mathrm{J} & 35 & - & - & - & - & - & - & - \\ \mathrm{A} & 586 & 586 & 0.0 & 586 & 586 & 0.91(0.01) & 0.91(0.01) & 0.91(0.01) \\ \mathrm{J} & 113 & 114 & 1.6 & 113 & 122 & 0.76(0.04) & 0.76(0.04) & 0.76(0.04) \\ \mathrm{A} & 47 & 50 & 2.7 & 47 & 61 & 0.61(0.08) & 0.61(0.08) & 0.61(0.08)\end{array}$

Cottus bairdi 
Appendix 3.7 continued

\begin{tabular}{|c|c|c|c|c|c|c|c|c|c|}
\hline Cottus bairdi & $\mathrm{J}$ & 167 & 171 & 2.7 & 168 & 180 & $0.71(0.04)$ & $0.71(0.04)$ & $0.71(0.04)$ \\
\hline Etheostoma blennioides & A & 34 & - & - & - & - & - & - & - \\
\hline Etheostoma blennioides & $\mathrm{J}$ & 3 & - & - & - & - & - & - & - \\
\hline Etheostoma caeruleum & A & 19 & - & - & - & - & - & - & - \\
\hline Etheostoma caeruleum & $\mathrm{J}$ & 26 & - & - & - & - & - & - & - \\
\hline Etheostoma flabellare & A & 1051 & 1086 & 8.2 & 1073 & 1105 & $0.68(0.02)$ & $0.68(0.02)$ & $0.68(0.02)$ \\
\hline Etheostoma flabellare & $\mathrm{J}$ & 260 & 285 & 19.4 & 266 & 356 & $0.70(0.05)$ & $0.46(0.14)$ & $0.46(0.14)$ \\
\hline Etheostoma osburni & A & 28 & - & - & - & - & - & - & - \\
\hline Etheostoma osburni & $\mathrm{J}$ & 2 & - & - & - & - & - & - & - \\
\hline Hypentelium nigricans & $\mathrm{A}$ & 10 & - & - & - & - & - & - & - \\
\hline Hypentelium nigricans & $\mathrm{J}$ & 52 & 52 & 0.0 & 52 & 52 & $0.83(0.05)$ & $0.90(0.09)$ & $0.90(0.09)$ \\
\hline Lepomis auritus & A & 1 & - & - & - & - & - & - & - \\
\hline Lepomis auritus & $\mathrm{J}$ & 2 & - & - & - & - & - & - & - \\
\hline Luxilus chrysocephalus & A & $67 *$ & - & - & - & - & - & - & - \\
\hline Luxilus chrysocephalus & $\mathrm{J}$ & 99 & 112 & 16.5 & 101 & 187 & $0.65(0.11)$ & $0.41(0.22)$ & $0.41(0.22)$ \\
\hline Micropterus dolomieu & A & 0 & - & - & - & - & - & - & - \\
\hline Micropterus dolomieu & $\mathrm{J}$ & 44 & 44 & 0.0 & 44 & 44 & $0.84(0.06)$ & $0.88(0.12)$ & $0.88(0.12)$ \\
\hline Nocomis leptocephalus & A & 77 & 77 & 0.1 & 77 & 77 & $0.94(0.03)$ & $0.71(0.17)$ & $0.71(0.17)$ \\
\hline Nocomis leptocephalus & $\mathrm{J}$ & 131 & 132 & 2.2 & 131 & 145 & $0.86(0.03)$ & $0.73(0.16)$ & $0.73(0.16)$ \\
\hline Notropis telescopus & A & 619 & 818 & 184.7 & 661 & 1552 & $0.61(0.14)$ & $0.21(0.14)$ & $0.21(0.14)$ \\
\hline Notropis telescopus & $\mathrm{J}$ & 17 & - & - & - & - & - & - & - \\
\hline Notropis rubellus & A & 28 & - & - & - & - & - & - & - \\
\hline Notropis scabriceps & A & 177 & 192 & 16.4 & 180 & 262 & $0.76(0.72)$ & $0.43(0.20)$ & $0.43(0.20)$ \\
\hline Notropis volucellus & A & 12 & - & - & - & - & - & - & - \\
\hline Percina roanoka & A & 7 & - & - & - & - & - & - & - \\
\hline Phoxinus oreas & A & 22 & - & - & - & - & - & - & - \\
\hline Phoxinus oreas & $\mathrm{J}$ & 4 & - & - & - & - & - & - & - \\
\hline Pimephales notatus & A & $233^{*}$ & - & - & - & - & - & - & - \\
\hline Pimephales notatus & $\mathrm{J}$ & 6 & - & - & - & - & - & - & - \\
\hline Rhinichthys obtusus & A & 5 & - & - & - & - & - & - & - \\
\hline Rhinichthys obtusus & $\mathrm{J}$ & 7 & - & - & - & - & - & - & - \\
\hline Semotilus atromaculatus & A & 62 & 67 & 4.3 & 64 & 89 & $0.71(0.07)$ & $0.60(0.21)$ & $0.60(0.21)$ \\
\hline Semotilus atromaculatus & $\mathrm{J}$ & 66 & 69 & 4.9 & 66 & 89 & $0.79(0.07)$ & $0.73(0.16)$ & $0.73(0.16)$ \\
\hline
\end{tabular}

\section{Site A3}

$\begin{array}{lccccccccc}\text { Campostoma anomalum } & \mathrm{A} & 90 & 91 & 2.2 & 90 & 104 & 0.65(0.06) & 0.85(0.07) & 0.85(0.07) \\ \text { Campostoma anomalus } & \mathrm{J} & 62 & 62 & 0.1 & 62 & 62 & 0.22(0.52) & 0.10(0.32) & 0.10(0.32) \\ \text { Catostomus commersoni } & \mathrm{A} & 11 & - & - & - & - & - & - & - \\ \text { Catostomus commersoni } & \mathrm{J} & 42 * & - & - & - & - & - & - & - \\ \text { Cottus bairdi } & \mathrm{A} & 388 & 403 & 7.8 & 394 & 427 & 0.58(0.03) & 0.70(0.06) & 0.70(0.06) \\ \text { Cottus bairdi } & \mathrm{J} & 162 & 168 & 4.8 & 163 & 186 & 0.54(0.04) & 0.71(0.08) & 0.71(0.08) \\ \text { Etheostoma blennioides } & \mathrm{A} & 4 & - & - & - & - & - & - & - \\ \text { Etheostoma flabellare } & \mathrm{A} & 1037 & 1133 & 33.4 & 1086 & 1223 & 0.66(0.02) & 0.50(0.06) & 0.50(0.06) \\ \text { Etheostoma flabellare } & \mathrm{J} & 347 & 3350 & 3.2 & 348 & 363 & 0.79(0.02) & 0.77(0.07) & 0.77(0.07)\end{array}$


Appendix 3.7 continued

$\begin{array}{lccccccccc}\text { Etheostoma osburni } & \text { A } & 16 & - & - & - & - & - & - & - \\ \text { Etheostoma osburni } & \text { J } & 2 & - & - & - & - & - & - & - \\ \text { Exoglossum laurae } & \text { A } & 11 & - & - & - & - & - & - & - \\ \text { Exoglossum laurae } & \text { J } & 5 & - & - & - & - & - & - & - \\ \text { Hypentelium nigricans } & \text { A } & 4 & - & - & - & - & - & - & - \\ \text { Hypentelium nigricans } & \text { J } & 3 & - & - & - & - & - & - & - \\ \text { Lepomis macrochirus } & \text { J } & 2 & - & - & - & - & - & - & - \\ \text { Micropterus salmoides } & \text { J } & 7 & - & - & - & - & - & - & - \\ \text { Oncorhynchus mykiss } & \text { A } & 2 & - & - & - & - & - & - & - \\ \text { Phoxinus oreas } & \text { A } & 329 & 336 & 6.0 & 331 & 359 & 0.81(0.03) & 0.65(0.10) & 0.65(0.10) \\ \text { Phoxinus oreas } & \text { J } & 7 & - & - & - & - & - & - & - \\ \text { Rhinichthys obtusus } & \text { A } & 494 & 496 & 2.1 & 494 & 505 & 0.78(0.02) & 0.85(0.04) & 0.85(0.04) \\ \text { Rhinichthys obtusus } & \text { J } & 43 & 43 & 1.8 & 43 & 55 & 0.67(0.08) & 0.74(0.17) & 0.74(0.17) \\ \text { Rhinichthys cataractae } & \text { A } & 7 & - & - & - & - & - & - & - \\ \text { Rhinichthys cataractae } & \text { J } & 8 & - & - & - & - & - & - & - \\ \text { Salmo trutta } & \text { A } & 6 & - & - & - & - & - & - & - \\ \text { Salmo trutta } & \text { J } & 10 & - & - & - & - & - & - & - \\ \text { Salvelinus fontinalis } & \text { A } & 3 & - & - & - & - & - & - & - \\ \text { Salvelinus fontinalis } & \text { J } & 3 & - & - & - & - & - & - & - \\ \text { Semotilus atromaculatus } & \text { A } & 3 & - & - & - & - & - & - & - \\ \text { Semotilus atromaculatus } & \text { J } & 27 & - & - & - & - & - & - & -\end{array}$

\section{Site A4}

Ambloplites rupestris

Ambloplites rupestris

Campostoma anomalum

Campostoma anomalum

$\begin{array}{ccc}\text { A } & 39 & - \\ \text { J } & 4 & -\end{array}$

$\begin{array}{llllll}\text { A } & 467 & 476 & 5.7 & 470 & 495\end{array}$

$\begin{array}{lllll}\mathrm{J} & 57 & 60 & 3.8 & 57\end{array}$

Cottus bairdi

Cottus bairdi

Cyprinella galactura

Etheostoma blennioides

Etheostoma flabellare

Etheostoma flabellare

Etheostoma osburni

Exoglossum laurae

Hypentelium nigricans

Hypentelium nigricans

Micropterus dolomieu

Micropterus dolomieu

Nocomis leptocephalus

Nocomis leptocephalus

Nocomis platyrhynchus

Nocomis platyrhynchus

Notropis scabriceps

A 18 - $\begin{array}{llllll}\text { A } & 222 & 357 & 126.1 & 251 & 859\end{array}$

$\begin{array}{lllll}\mathrm{J} & 44 & 44 & 0.0 & 44\end{array}$

A $22 \quad-\quad-\quad-$

A $24 \quad-\quad-\quad-$

$\begin{array}{lllll}\text { A } & 484 & 521 & 15.8 & 500\end{array}$

$4.1 \quad 281$

566

299

J 279

$\mathrm{J}$

A 22

J $49 *-$

J $21 \quad-\quad-$

A $34 \quad-\quad-\quad$

J 2

A $108 \quad 109$
$0.59(0.03)$

$0.59(0.06) \quad 0.59(0.06)$

$0.78(0.02) \quad 0.71(0.07) \quad 0.71(0.07)$

$0.57(0.07) \quad 0.65(0.16) \quad 0.65(0.16)$

$\begin{array}{lll}0.34(0.12) & 0.24(0.15) & 0.24(0.15)\end{array}$

$0.66(0.07) \quad 0.83(0.09) \quad 0.83(0.09)$

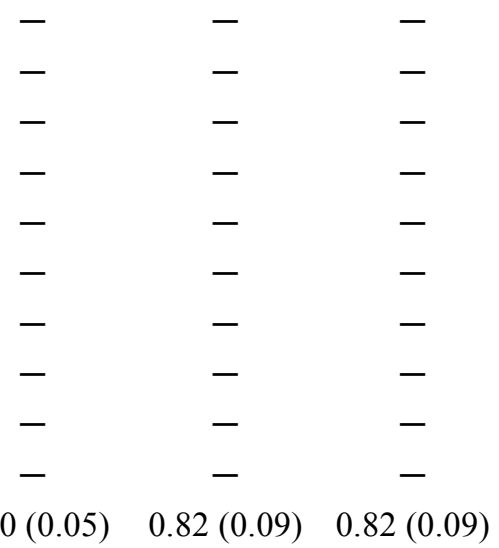


Appendix 3.7 continued

Notropis scabriceps

Notropis telescopus

Notropis telescopus

Phoxinus oreas

Pimephales notatus

Rhinichthys obtusus

Rhinichthys obtusus

Semotilus atromaculatus

$\begin{array}{ccccccccc}\mathrm{J} & 1 & - & - & - & - & - & - & - \\ \mathrm{A} & 995 & 1076 & 1.6 & 1034 & 1166 & 0.70(0.03) & 0.49(0.07) & 0.49(0.07) \\ \mathrm{J} & 56 & 56 & 0.0 & 56 & 56 & 0.80(0.05) & 0.92(0.08) & 0.92(0.08) \\ \mathrm{A} & 1 & - & - & - & - & - & - & - \\ \mathrm{A} & 4 & - & - & - & - & - & - & - \\ \mathrm{A} & 28 & - & - & - & - & - & - & - \\ \mathrm{J} & 11 & - & - & - & - & - & - & - \\ \mathrm{J} & 5 & - & - & - & - & - & - & -\end{array}$

\section{Site A5}

Ambloplites rupestris

Ambloplites rupestris

Campostoma anomalum

Campostoma anomalus

Cottus bairdi

Cottus bairdi

Cyprinella galactura

Cyprinella galactura

Etheostoma blennioides

Etheostoma blennioides

Etheostoma caeruleum

Etheostoma caeruleum

Etheostoma flabellare

Etheostoma flabellare

Etheostoma osburni

Hypentelium nigricans

Hypentelium nigricans

Lepomis auritus

Lepomis auritus

Luxilus chrysocephalus

Luxilus chrysocephalus

Micropterus dolomieu

Micropterus dolomieu

Nocomis leptocephalus

Nocomis leptocephalus

Nocomis platyrhynchus

Nocomis platyrhynchus

Notropis telescopus

Notropis telescopus

Percina roanoka

Percina roanoka

Pimephales notatus

Pimephales notatus

Semotilus atromaculatus

\begin{tabular}{|c|c|c|c|c|c|c|c|c|}
\hline A & 37 & - & - & - & - & - & - & - \\
\hline $\mathrm{J}$ & 35 & - & - & - & - & - & - & - \\
\hline A & 738 & 739 & 1.5 & 738 & 746 & $0.86(0.01)$ & $0.86(0.01)$ & $0.86(0.01)$ \\
\hline $\mathrm{J}$ & 93 & 93 & 0.0 & 93 & 93 & $0.81(0.03)$ & $0.81(0.03)$ & $0.81(0.03)$ \\
\hline A & 30 & - & - & - & - & - & - & - \\
\hline $\mathrm{J}$ & 9 & - & - & - & - & - & - & - \\
\hline A & $160^{*}$ & - & - & - & - & - & - & - \\
\hline $\mathrm{J}$ & 64 & 66 & 2.4 & 64 & 76 & $0.65(0.07)$ & $0.65(0.07)$ & $0.65(0.07)$ \\
\hline A & 3 & - & - & - & - & - & - & - \\
\hline $\mathrm{J}$ & 1 & - & - & - & - & - & - & - \\
\hline A & 277 & 317 & 13.4 & 298 & 353 & $0.50(0.04)$ & $0.50(0.04)$ & $0.50(0.04)$ \\
\hline $\mathrm{J}$ & 82 & 103 & 2.7 & 89 & 145 & $0.41(0.09)$ & $0.41(0.09)$ & $0.41(0.09)$ \\
\hline A & 159 & 175 & 7.3 & 166 & 196 & $0.55(0.05)$ & $0.55(0.05)$ & $0.55(0.05)$ \\
\hline $\mathrm{J}$ & $71^{*}$ & - & - & - & - & - & - & - \\
\hline A & 6 & - & - & - & - & - & - & - \\
\hline A & 3 & - & - & - & - & - & - & - \\
\hline $\mathrm{J}$ & 22 & - & - & - & - & - & - & - \\
\hline A & 14 & - & - & - & - & - & - & - \\
\hline $\mathrm{J}$ & 50 & 50 & 0.1 & 50 & 50 & $0.83(0.05)$ & $0.83(0.05)$ & $0.83(0.05)$ \\
\hline A & 11 & - & - & - & - & - & - & - \\
\hline $\mathrm{J}$ & 14 & - & - & - & - & - & - & - \\
\hline A & 6 & - & - & - & - & - & - & - \\
\hline $\mathrm{J}$ & 51 & 51 & 1.3 & 51 & 59 & $0.74(0.07)$ & $0.74(0.07)$ & $0.74(0.07)$ \\
\hline A & 79 & 79 & 0.6 & 79 & 82 & $0.81(0.04)$ & $0.81(0.04)$ & $0.81(0.04)$ \\
\hline $\mathrm{J}$ & $51^{*}$ & - & - & - & - & - & - & - \\
\hline A & 16 & - & - & - & - & - & - & - \\
\hline $\mathrm{J}$ & 29 & - & - & - & - & - & - & - \\
\hline A & 428 & 445 & 6.0 & 437 & 461 & $0.66(0.03)$ & $0.66(0.03)$ & $0.66(0.03)$ \\
\hline $\mathrm{J}$ & $410^{*}$ & - & - & - & - & - & - & - \\
\hline A & $57 *$ & - & - & - & - & - & - & - \\
\hline $\mathrm{J}$ & 3 & - & - & - & - & - & - & - \\
\hline A & 52 & 53 & 1.4 & 52 & 61 & $0.73(0.07)$ & $0.73(0.07)$ & $0.73(0.07)$ \\
\hline $\mathrm{J}$ & 9 & - & - & - & - & - & - & - \\
\hline $\mathrm{J}$ & 3 & - & - & - & - & - & - & - \\
\hline
\end{tabular}


Appendix 3.7 continued

Site A6

Ambloplites rupestris

Ambloplites rupestris

Campostoma anomalum

Campostoma anomalus

Cottus bairdi

Cottus bairdi

Cyprinella galactura

Etheostoma blennioides

Etheostoma blennioides

Etheostoma caeruleum

Etheostoma flabellare

Etheostoma osburni

Exoglossum laurae

Exoglossum laurae

Hypentelium nigricans

Hypentelium nigricans

Lepomis cyanellus

Luxilus chrysocephalus

Luxilus chrysocephalus

Micropterus dolomieu

Nocomis platyrhynchus

Nocomis $s p$

Notropis telescopus

Notropis telescopus

Notropis scabriceps

Phoxinus oreas

Pimephales notatus

Pimephales notatus

Rhinichthys obtusus

Rhinichthys obtusus

Semotilus atromaculatus

Semotilus atromaculatus

\begin{tabular}{|c|c|c|c|c|c|c|c|c|}
\hline A & 7 & - & - & - & - & - & - & - \\
\hline $\mathrm{J}$ & 12 & - & - & - & - & - & - & - \\
\hline A & 1134 & 1158 & 9.1 & 1146 & 1183 & $0.72(0.02)$ & $0.72(0.04)$ & $0.72(0.04)$ \\
\hline $\mathrm{J}$ & 397 & 416 & 11.7 & 403 & 455 & $0.73(0.03)$ & 0.59 (0.09) & $0.59(0.09)$ \\
\hline A & 643 & 683 & 17.3 & 661 & 733 & $0.67(0.02)$ & $0.58(0.07)$ & $0.58(0.07)$ \\
\hline $\mathrm{J}$ & 109 & 114 & 4.7 & 110 & 133 & $0.47(0.05)$ & $0.69(0.10)$ & $0.69(0.10)$ \\
\hline A & 5 & - & - & - & - & - & - & - \\
\hline A & 42 & 42 & 0.0 & 42 & 42 & $0.88(0.05)$ & $1.00(0.00)$ & $1.00(0.00)$ \\
\hline $\mathrm{J}$ & 1 & - & - & - & - & - & - & - \\
\hline A & 16 & - & - & - & - & - & - & - \\
\hline A & 2030 & 2102 & 21.2 & 2071 & 2157 & $0.78(0.01)$ & $0.61(0.04)$ & $0.61(0.04)$ \\
\hline A & 4 & - & - & - & - & - & - & - \\
\hline A & 6 & - & - & - & - & - & - & - \\
\hline $\mathrm{J}$ & 36 & - & - & - & - & - & - & - \\
\hline A & 6 & - & - & - & - & - & - & - \\
\hline $\mathrm{J}$ & 27 & - & - & - & - & - & - & - \\
\hline $\mathrm{J}$ & 6 & - & - & - & - & - & - & - \\
\hline A & 43 & 43 & 0.0 & 43 & 43 & $0.86(0.05)$ & $0.86(0.13)$ & $0.86(0.13)$ \\
\hline $\mathrm{J}$ & 92 & 92 & 0.0 & 92 & 92 & $0.76(0.04)$ & $0.85(0.07)$ & $0.85(0.07)$ \\
\hline $\mathrm{J}$ & 7 & - & - & - & - & - & - & - \\
\hline A & 48 & 48 & 0.0 & 48 & 48 & $0.85(0.05)$ & $1.00(0.00)$ & $1.00(0.00)$ \\
\hline $\mathrm{J}$ & 93 & 96 & 4.0 & 93 & 115 & $0.69(0.06)$ & $0.66(0.15)$ & $0.66(0.15)$ \\
\hline A & 500 & 506 & 5.6 & 502 & 528 & $0.87(0.02)$ & $0.67\left(\begin{array}{ll}0 & 10\end{array}\right)$ & $0.67\left(\begin{array}{ll}0 & 10\end{array}\right)$ \\
\hline $\mathrm{J}$ & 23 & - & - & - & - & - & - & - \\
\hline A & 27 & - & - & - & - & - & - & - \\
\hline A & 1 & - & - & - & - & - & - & - \\
\hline A & 77 & 77 & 0.0 & 77 & 77 & $0.87(0.04)$ & $0.83(0.11)$ & $0.83(0.11)$ \\
\hline $\mathrm{J}$ & 5 & - & - & - & - & - & - & - \\
\hline A & 46 & 46 & 0.0 & 46 & 46 & $0.85(0.05)$ & $0.78(0.14)$ & $0.78(0.14)$ \\
\hline $\mathrm{J}$ & 7 & - & - & - & - & - & - & - \\
\hline A & 10 & - & - & - & - & - & - & - \\
\hline $\mathrm{J}$ & 78 & 78 & 0.0 & 78 & 78 & $0.9(0.03)$ & $0.89(0.10)$ & $0.89(0.10)$ \\
\hline
\end{tabular}

\section{Site A7}

Ambloplites rupestris

Ambloplites rupestris

Campostoma anomalum

Campostoma anomalus

Cyprinella galactura

Cottus bairdi

Cottus bairdi

Etheostoma caeruleum 
Appendix 3.7 continued

$\begin{array}{lccccccccc}\text { Etheostoma flabellare } & \text { A } & 1011 & 1018 & 3.2 & 1014 & 1028 & 0.80(0.01) & 0.80(0.01) & 0.80(0.01) \\ \text { Etheostoma flabellare } & \text { J } & 3 & - & - & - & - & - & - & - \\ \text { Exoglossum laurae } & \text { A } & 1 & - & - & - & - & - & - & - \\ \text { Hypentelium nigricans } & \text { A } & 32 & - & - & - & - & - & - & - \\ \text { Hypentelium nigricans } & \text { J } & 25 & - & - & - & - & - & - & - \\ \text { Luxilus chrysocephalus } & \text { A } & 16 & - & - & - & - & - & - & - \\ \text { Luxilus chrysocephalus } & \text { J } & 1 & - & - & - & - & - & - & - \\ \text { Micropterus dolomieu } & \text { A } & 5 & - & - & - & - & - & - & - \\ \text { Micropterus dolomieu } & \text { J } & 6 & - & - & - & - & - & - & - \\ \text { Nocomis platyrhynchus } & \text { A } & 7 & - & - & - & - & - & - & - \\ \text { Notropis telescopus } & \text { A } & 209 & 222 & 6.0 & 215 & 240 & 0.60(0.04) & 0.60(0.04) & 0.60(0.04) \\ \text { Notropis scabriceps } & \text { A } & 33 & - & - & - & - & - & - & - \\ \text { Notropis scabriceps } & \text { J } & 1 & - & - & - & - & - & - & - \\ \text { Notropis photogenis } & \text { A } & 72 & 72 & 0.0 & 72 & 72 & 0.93(0.03) & 0.93(0.03) & 0.93(0.03) \\ \text { Notropis photogenis } & \text { J } & 13 & - & - & - & - & - & - & - \\ \text { Pimephales notatus } & \text { A } & 3 & - & - & - & - & - & - & - \\ \text { Pimephales notatus } & \text { J } & 1 & - & - & - & - & - & - & - \\ \text { Rhinichthys obtusus } & \text { A } & 224 & 225 & 1.4 & 215 & 240 & 0.81(0.03) & 0.81(0.03) & 0.81(0.03) \\ \text { Semotilus atromaculatus } & \text { A } & 17 & - & - & - & - & - & - & - \\ \text { Semotilus atromaculatus } & \text { J } & 10 & - & - & - & - & - & - & -\end{array}$

Site A8

Ambloplites rupestris

Campostoma anomalum

Campostoma anomalus

Cottus bairdi

Cottus bairdi

Etheostoma flabellare

Hypentelium nigricans

Hypentelium nigricans

Micropterus dolomieu

Nocomis platyrhynchus

Notropis telescopus

Phoxinus oreas

Rhinichthys obtusus

Salvelinus fontinalis

Semotilus atromaculatus

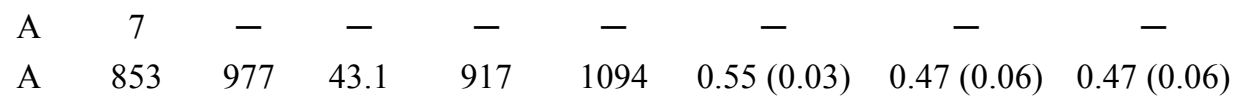

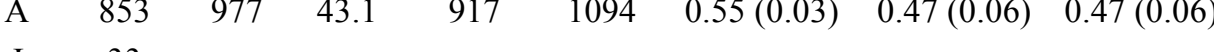

$\begin{array}{ccccccccc}\mathrm{J} & 33 & - & - & - & - & - & - & - \\ \mathrm{A} & 564^{*} & - & - & - & - & - & - & -\end{array}$

$\begin{array}{lllllllll}\mathrm{J} & 48 & 48 & 0.0 & 48 & 48 & 0.69(0.07) & 1.00(0.00) & 1.00(0.00)\end{array}$

$\begin{array}{lllllllll}\text { A } & 825 & 920 & 32.7 & 874 & 1008 & 0.57(0.03) & 0.51(0.06) & 0.51(0.06)\end{array}$

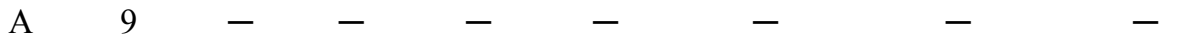

$\begin{array}{llllllllll}\mathrm{J} & 2 & - & - & - & - & - & - & - & -\end{array}$

$\begin{array}{llllllllll}\mathrm{J} & 5 & - & - & - & - & - & - & -\end{array}$

$\begin{array}{lllllllll}\mathrm{A} & 3 & - & - & - & - & - & - & -\end{array}$

$\begin{array}{lllllllll}\text { A } & 104 & 104 & 0.0 & 104 & 104 & 0.74(0.04) & 0.90(0.05) & 0.90(0.05)\end{array}$

$\begin{array}{ccccccccc}\mathrm{A} & 12 & - & - & - & - & - & - & - \\ \mathrm{A} & 255 & 268 & 8.9 & 259 & 299 & 0.66(0.04) & 0.62(0.10) & 0.62(0.10)\end{array}$

A $\quad 21 \quad-\quad \begin{array}{lllllllll} & 2 & - & - & - & - & - & - & -\end{array}$

$\begin{array}{llllllllll}\mathrm{J} & 2 & - & - & - & - & - & - & -\end{array}$

Site A9

Campostoma anomalum

Campostoma anomalus

Catostomus commersoni

Catostomus commersoni

Clinostomus funduloides

$\begin{array}{ccccccccc}\mathrm{A} & 30 & - & - & - & - & - & - & - \\ \mathrm{J} & 2 & - & - & - & - & - & - & - \\ \mathrm{A} & 7 & - & - & - & - & - & - & - \\ \mathrm{J} & 3 & - & - & - & - & - & - & - \\ \mathrm{A} & 360 & 372 & 8.2 & 363 & 400 & 0.76(0.03) & 0.63(0.09) & 0.63(0.09)\end{array}$


Appendix 3.7 continued

$\begin{array}{lccccccccc}\text { Clinostomus funduloides } & \text { J } & 126 & 126 & 0.0 & 126 & 126 & 0.51(0.04) & 0.97(0.02) & 0.97(0.02) \\ \text { Cottus kanawhae } & \text { A } & 117 & 132 & 16.9 & 120 & 205 & 0.64(0.09) & 0.43(0.20) & 0.43(0.20) \\ \text { Cottus kanawhae } & \text { J } & 446 & 460 & 7.6 & 451 & 484 & 0.65(0.02) & 0.69(0.06) & 0.69(0.06) \\ \text { Ericymba buccata } & \text { A } & 1 & - & - & - & - & - & - & - \\ \text { Etheostoma caeruleum } & \text { A } & 182 & 190 & 6.7 & 184 & 216 & 0.69(0.04) & 0.63(0.12) & 0.63(0.12) \\ \text { Etheostoma caeruleum } & \text { J } & 1 & - & - & - & - & - & - & - \\ \text { Etheostoma flabellare } & \text { A } & 306 & 319 & 9.7 & 310 & 354 & 0.75(0.03) & 0.59(0.11) & 0.59(0.11) \\ \text { Etheostoma flabellare } & \text { J } & 9 & - & - & - & - & - & - & - \\ \text { Hypentelium nigricans } & \text { A } & 1 & - & - & - & - & - & - & - \\ \text { Hypentelium nigricans } & \text { J } & 6 & - & - & - & - & - & - & - \\ \text { Luxilus chrysocephalus } & \text { A } & 3 & - & - & - & - & - & - & - \\ \text { Nocomis leptocephalus } & \text { A } & 51 * & - & - & - & - & - & - & - \\ \text { Nocomis leptocephalus } & \text { J } & 42 & 42 & 0.0 & 42 & 42 & 0.62(0.07) & 0.84(0.08) & 0.84(0.08) \\ \text { Notropis telescopus } & \text { A } & 20 & - & - & - & - & - & - & - \\ \text { Phoxinus oreas } & \text { A } & 129 & 132 & 3.2 & 129 & 146 & 0.61(0.07) & 0.75(0.09) & 0.75(0.09) \\ \text { Phoxinus oreas } & \text { J } & 26 & - & - & - & - & - & - & - \\ \text { Rhinichthys obtusus } & \text { A } & 319 & 327 & 6.0 & 321 & 349 & 0.77(0.03) & 0.67(0.09) & 0.67(0.09) \\ \text { Rhinichthys obtusus } & \text { J } & 14 & - & - & - & - & - & - & - \\ \text { Semotilus atromaculatus } & \text { A } & 41 & 41 & 0.0 & 41 & 41 & 0.93(0.04) & 0.75(0.22) & 0.75(0.22) \\ \text { Semotilus atromaculatus } & \text { J } & 31 & - & - & - & - & - & - & -\end{array}$

Site A10

$\begin{array}{lccccccccc}\text { Ambloplites rupestris } & \mathrm{A} & 57 & 61 & 6.0 & 57 & 91 & 0.62(0.09) & 0.56(0.22) & 0.56(0.22) \\ \text { Ambloplites rupestris } & \mathrm{J} & 48 & 48 & 0.0 & 48 & 48 & 0.67(0.07) & 0.84(0.08) & 0.84(0.08) \\ \text { Campostoma anomalum } & \mathrm{A} & 260 * & - & - & - & - & - & - & - \\ \text { Campostoma anomalus } & \mathrm{J} & 87 & 91 & 4.3 & 88 & 110 & 0.56(0.06) & 0.67(0.13) & 0.67(0.13) \\ \text { Cottus kanawhae } & \mathrm{A} & 11 & - & - & - & - & - & - & - \\ \text { Cottus kanawhae } & \mathrm{J} & 31 & - & - & - & - & - & - & - \\ \text { Cyprinella galactura } & \mathrm{A} & 80 & 80 & 0.0 & 80 & 80 & 0.61(0.05) & 0.86(0.05) & 0.86(0.05) \\ \text { Cyprinella galactura } & \mathrm{J} & 89 & 98 & 9.2 & 91 & 136 & 0.52(0.07) & 0.55(0.16) & 0.55(0.16) \\ \text { Etheostoma blennioides } & \mathrm{A} & 7 & - & - & - & - & - & - & - \\ \text { Etheostoma caeruleum } & \mathrm{A} & 58 & 58 & 0.0 & 80 & 80 & 0.72(0.06) & 0.84(0.08) & 0.84(0.08) \\ \text { Etheostoma caeruleum } & \mathrm{J} & 17 & - & - & - & - & - & - & - \\ \text { Etheostoma flabellare } & \mathrm{A} & 80 & 80 & 0.6 & 80 & 82 & 0.75(0.05) & 0.83(0.09) & 0.83(0.09) \\ \text { Etheostoma flabellare } & \mathrm{J} & 10 & - & - & - & - & - & - & - \\ \text { Hypentelium nigricans } & \mathrm{A} & 5 & - & - & - & - & - & - & - \\ \text { Hypentelium nigricans } & \mathrm{J} & 11 & - & - & - & - & - & - & - \\ \text { Lepomis auritus } & \mathrm{A} & 1 & - & - & - & - & - & - & - \\ \text { Lepomis auritus } & \mathrm{J} & 5 & - & - & - & - & - & - & - \\ \text { Lepomis macrochirus } & \mathrm{J} & 1 & - & - & - & - & - & - & - \\ \text { Luxilus chrysocephalus } & \mathrm{A} & 81 & 81 & 0.0 & 81 & 81 & 0.79(0.05) & 0.90(0.07) & 0.90(0.07) \\ \text { Luxilus chrysocephalus } & \mathrm{J} & 130 & 134 & 4.6 & 131 & 154 & 0.71(0.05) & 0.66(0.13) & 0.66(0.13) \\ \text { Micropterus dolomieu } & \mathrm{A} & 11 & - & - & - & - & - & - & - \\ \text { Micropterus dolomieu } & \mathrm{J} & 11 & - & - & - & - & - & - & -\end{array}$


Appendix 3.7 continued

$\begin{array}{lccccccccc}\text { Nocomis leptocephalus } & \text { A } & 39 & - & - & - & - & - & - & - \\ \text { Nocomis platyrhynchus } & \text { A } & 4 & - & - & - & - & - & - & - \\ \text { Nocomis sp } & \text { J } & 150 & 151 & 1.6 & 150 & 160 & 0.66(0.04) & 0.84(0.06) & 0.84(0.06) \\ \text { Notopis photogenis } & \mathrm{J} & 3 & - & - & - & - & - & - & - \\ \text { Notropis photogenis } & \mathrm{A} & 6 & - & - & - & - & - & - & - \\ \text { Notropis rubellus } & \mathrm{A} & 11 & - & - & - & - & - & - & - \\ \text { Notropis telescopus } & \mathrm{A} & 187 & 199 & 8.6 & 190 & 229 & 0.60(0.04) & 0.61(0.11) & 0.61(0.11) \\ \text { Notropis telescopus } & \mathrm{J} & 2 & - & - & - & - & - & - & - \\ \text { Notropis volucellus } & \mathrm{A} & 75 & 77 & 3.4 & 75 & 95 & 0.73(0.06) & 0.66(0.18) & 0.66(0.18) \\ \text { Notropis volucellus } & \mathrm{J} & 2 & - & - & - & - & - & - & - \\ \text { Pimephales notatus } & \mathrm{A} & 295 & 305 & 1.5 & 304 & 313 & 0.78(0.02) & 0.87(0.05) & 0.87(0.05) \\ \text { Pimephales notatus } & \mathrm{J} & 100 & 106 & 5.3 & 101 & 127 & 0.41(0.05) & 0.68(0.10) & 0.68(0.10) \\ \text { Rhinichthys obtususs } & \mathrm{J} & 1 & - & - & - & - & - & - & - \\ \text { Salmo trutta } & \mathrm{A} & 4 & - & - & - & - & - & - & - \\ \text { Salmo trutta } & \mathrm{J} & 1 & - & - & - & - & - & - & - \\ \text { Semotilus atromaculatus } & \mathrm{A} & 22 & - & - & - & - & - & - & - \\ \text { Semotilus atromaculatus } & \mathrm{J} & 44 & 44 & 1.5 & 44 & 44 & 0.77(0.06) & 0.83(0.11) & 0.83(0.11)\end{array}$

Site A11

Ambloplites rupestris

Campostoma anomalum

Campostoma anomalus

Clinostomus funduloides

Clinostomus funduloides

Cottus bairdi

Cottus bairdi

Cyprinella galactura

Cyprinella galactura

Etheostoma blennioides

Etheostoma flabellare

Etheostoma flabellare

Etheostoma osburni

Exoglossum laurae

Exoglossum laurae

Hypentelium nigricans

Hypentelium nigricans

Luxilus chrysocephalus

Micropterus dolomieu

Micropterus dolomieu

Nocomis platyrhynchus

Nocomis $s p$

Notropis telescopus

Notropis rubellus

Notropis photogenis

$\begin{array}{ccccccccc}\text { A } & 27 & - & - & - & - & - & - & - \\ \mathrm{A} & 174 & 199 & 10.4 & 185 & 228 & 0.50(0.05) & 0.50(0.05) & 0.50(0.05) \\ \mathrm{J} & 7 & - & - & - & - & - & - & - \\ \mathrm{A} & 3 & - & - & - & - & - & - & - \\ \mathrm{J} & 1 & - & - & - & - & - & - & - \\ \mathrm{A} & 84 & 101 & 10.0 & 90 & 133 & 0.45(0.08) & 0.45(0.08) & 0.45(0.08) \\ \mathrm{J} & 5 & - & - & - & - & - & - & - \\ \mathrm{A} & 20 & - & - & - & - & - & - & - \\ \mathrm{J} & 1 & - & - & - & - & - & - & - \\ \mathrm{A} & 6 & - & - & - & - & - & - & - \\ \mathrm{A} & 201 & 227 & 10.4 & 213 & 256 & 0.51(0.05) & 0.51(0.05) & 0.51(0.05) \\ \mathrm{J} & 7 & - & - & - & - & - & - & - \\ \mathrm{A} & 3 & - & - & - & - & - & - & - \\ \mathrm{A} & 2 & - & - & - & - & - & - & - \\ \mathrm{J} & 4 & - & - & - & - & - & - & - \\ \mathrm{A} & 16 & - & - & - & - & - & - & - \\ \mathrm{J} & 2 & - & - & - & - & - & - & - \\ \mathrm{A} & 2 & - & - & - & - & - & - & - \\ \mathrm{A} & 7 & - & - & - & - & - & - & - \\ \mathrm{J} & 4 & - & - & - & - & - & - & - \\ \mathrm{A} & 81 & 95 & 9.0 & 86 & 133 & 0.46(0.08) & 0.46(0.08) & 0.46(0.08) \\ \mathrm{J} & 145 & 153 & 4.5 & 148 & 167 & 0.62(0.05) & 0.62(0.05) & 0.62(0.05) \\ \mathrm{A} & 596 & 642 & 11.4 & 624 & 670 & 0.58(0.02) & 0.58(0.02) & 0.58(0.02) \\ \mathrm{A} & 1 & & - & - & - & - & - & - \\ \mathrm{A} & 42 & 42 & 0.0 & 42 & 42 & 0.76(0.06) & 0.76(0.06) & 0.76(0.06) \\ & & & & & & & & \end{array}$


Appendix 3.7 continued

\begin{tabular}{|c|c|c|c|c|c|c|c|c|c|}
\hline Percina roanoka & $\mathrm{A}$ & 8 & - & - & - & - & - & - & - \\
\hline Rhinichthys cataractae & A & 6 & - & - & - & - & - & - & - \\
\hline Rhinichthys cataractae & $\mathrm{J}$ & 3 & - & - & - & - & - & - & - \\
\hline Rhinichthys obtusus & A & 2 & - & - & - & - & - & - & - \\
\hline Semotilus atromaculatus & $\mathrm{J}$ & 1 & - & - & - & - & - & - & - \\
\hline
\end{tabular}

Site A12 ( 2 pass site)

Campostoma anomalum

Catostomus commersoni

Cottus bairdi

Cottus bairdi

Etheostoma blennioides

Etheostoma flabellare

Etheostoma flabellare

Etheostoma osburni

Exoglossum laurae

Hypentelium nigricans

Phenacobius teretulus

Phoxinus oreas

Rhinichthys cataractae

Rhinichthys obtusus

Rhinichthys obtusus

Salmo trutta

Salmo trutta

Salvelinus fontinalis

$\begin{array}{ccccccccc}\text { A } & 20 & - & - & - & - & - & - & - \\ \mathrm{A} & 4 & - & - & - & - & - & - & - \\ \mathrm{A} & 108 & - & - & - & - & - & - & - \\ \mathrm{J} & 8 & - & - & - & - & - & - & - \\ \mathrm{A} & 1 & - & - & - & - & - & - & - \\ \mathrm{A} & 129 & - & - & - & - & - & - & - \\ \mathrm{J} & 1 & - & - & - & - & - & - & - \\ \mathrm{A} & 2 & - & - & - & - & - & - & - \\ \mathrm{J} & 4 & - & - & - & - & - & - & - \\ \mathrm{A} & 5 & - & - & - & - & - & - & - \\ \mathrm{A} & 1 & - & - & - & - & - & - & - \\ \mathrm{A} & 31 & - & - & - & - & - & - & - \\ \mathrm{A} & 10 & - & - & - & - & - & - & - \\ \mathrm{A} & 104 & - & - & - & - & - & - & - \\ \mathrm{J} & 1 & - & - & - & - & - & - & - \\ \mathrm{A} & 14 & - & - & - & - & - & - & - \\ \mathrm{J} & 5 & - & - & - & - & - & - & - \\ \mathrm{A} & 6 & - & - & - & - & - & - & -\end{array}$

Site A13

Ambloplites rupestris

Ambloplites rupestris

Campostoma anomalum

Campostoma anomalus

Cottus kanawhae

Cottus kanawhae

Cyprinella galactura

Cyprinella galactura

Etheostoma caeruleum

Etheostoma caeruleum

Etheostoma flabellare

Etheostoma flabellare

Etheostoma variatum

Hypentelium nigricans

Lepomis auritus

$\begin{array}{ccccccccc}\text { A } & 25 & - & - & - & - & - & - & - \\ \mathrm{J} & 4 & - & - & - & - & - & - & - \\ \mathrm{A} & 86 & 111 & 27.9 & 90 & 232 & 0.43(0.12) & 0.37(0.21) & 0.37(0.21) \\ \mathrm{J} & 111 & 114 & 3.5 & 112 & 129 & 0.56(0.05) & 0.73(0.10) & 0.73(0.10) \\ \mathrm{A} & 11 & - & - & - & - & - & - & - \\ \mathrm{J} & 17 & - & - & - & - & - & - & - \\ \mathrm{A} & 27 & - & - & - & - & - & - & - \\ \mathrm{J} & 13 & - & - & - & - & - & - & - \\ \mathrm{A} & 59 & 95 & 42.9 & 67 & 295 & 0.28(0.13) & 0.31(0.23) & 0.31(0.23) \\ \mathrm{J} & 6 & - & - & - & - & - & - & - \\ \mathrm{A} & 42 & 42 & 1.8 & 42 & 54 & 0.59(0.08) & 0.80(0.16) & 0.80(0.16) \\ \mathrm{J} & 3 & - & - & - & - & - & - & - \\ \mathrm{A} & 6 & - & - & - & - & - & - & - \\ \mathrm{J} & 3 & - & - & - & - & - & - & - \\ \mathrm{J} & 1 & - & - & - & - & - & - & -\end{array}$


Appendix 3.7 continued

$\begin{array}{lccccccccc}\text { Luxilus chrysocephalus } & \text { A } & 75^{*} & - & - & - & - & - & - & - \\ \text { Luxilus chrysocephalus } & \text { J } & 41 & 55 & 19.6 & 43 & 54 & 0.33(0.13) & 0.38(0.26) & 0.38(0.26) \\ \text { Micropterus dolomieu } & \text { A } & 1 & - & - & - & - & - & - & - \\ \text { Micropterus dolomieu } & \text { J } & 6 & - & - & - & - & - & - & - \\ \text { Nocomis leptocephalus } & \text { A } & 30 & - & - & - & - & - & - & - \\ \text { Nocomis platyrhynchus } & \text { A } & 6 & - & - & - & - & - & - & - \\ \text { Nocomis sp } & \text { J } & 52 & 52 & 0.4 & 52 & 53 & 0.60(0.07) & 0.84(0.08) & 0.84(0.08) \\ \text { Notropis telescopus } & \text { A } & 228^{*} & - & - & - & - & - & - & - \\ \text { Notropis telescopus } & \text { J } & 10 & - & - & - & - & - & - & - \\ \text { Percina roanoka } & \text { A } & 2 & - & - & - & - & - & - & - \\ \text { Pimephales notatus } & \text { A } & 5 & - & - & - & - & - & - & - \\ \text { Rhinichthys cataractae } & \text { A } & 4 & - & - & - & - & - & - & - \\ \text { Semotilus atromaculatus } & \text { A } & 5 & - & - & - & - & - & - & - \\ \text { Semotilus atromaculatus } & \text { J } & 1 & - & - & - & - & - & - & -\end{array}$

\section{Site A14}

Ambloplites rupestris

Campostoma anomalum

Campostoma anomalus

Clinostomus funduloides

Cottus kanawhae

Cottus kanawhae

Cyprinella galactura

Cyprinella galactura

Etheostoma caeruleum

Etheostoma flabellare

Etheostoma flabellare

Etheostoma variatum

Hypentelium nigricans

Hypentelium nigricans

Luxilus chrysocephalus

Luxilus chrysocephalus

Micropterus dolomieu

Micropterus dolomieu

Nocomis leptocephalus

Nocomis platyrhyhchus

Nocomis $s p$

Notropis telescopus

Notropis telescopus

Rhinichtys cataractae

Salmo trutta

Semotilus atromaculatus

A 180

240

48.7

195

433

$0.42(0.09)$

$0.34(0.15) \quad 0.34(0.15)$

$\begin{array}{llllll}\text { J } & 106 & 155 & 47.9 & 116 & 351\end{array}$

$0.30(0.10) \quad 0.33(0.18) \quad 0.33(0.18)$

$\begin{array}{llllll}\mathrm{J} & 2 & - & - & - & -\end{array}$
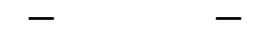

A 12

$\mathrm{J}$

A 27

J 8

A 46

A 16

J 4

A 1

A 2

A

111

$\begin{array}{lllll}\mathrm{J} & 145^{*} & - & - & -\end{array}$

1554

$25(0.25)$

$(0.22)$

$0.15(0.22)$

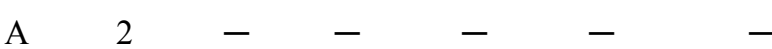

$\begin{array}{llllll}\mathrm{J} & 9 & - & - & -\end{array}$

Semotilus atromaculatus

$\begin{array}{lllll}\text { A } & 42 & 51 & 14.8 & 43\end{array}$

126

$0.47(0.15) \quad 0.40(0.28) \quad 0.40(0.28)$

A 1

$\begin{array}{lllll}\text { J } & 78 & 81 & 3.8 & 78\end{array}$

99

$0.54(0.06) \quad 0.70(0.13) \quad 0.70(0.13)$

$\begin{array}{lllll}\text { A } & 273 & 338 & 37.7 & 296\end{array}$

460

$0.43(0.06) \quad 0.42(0.11) \quad 0.42(0.11)$

$\begin{array}{llllll}\mathrm{J} & 20 & - & - & - & -\end{array}$


Appendix 3.7 continued

\section{Site A15}

Ambloplites rupestris

Ambloplites rupestris

Campostoma anomalum

Campostoma anomalum

Cottus kanawhae

Cottus kanawhae

Cyprinella galactura

Cyprinella galactura

Etheostoma blennioides

Etheostoma caeruleum

Etheostoma caeruleum

Etheostoma flabellare

Etheostoma flabellare

Etheostoma variatum

Hypentelium nigricans

Luxilus albeolus

Luxilus albeolus

Micropterus dolomieu

Micropterus dolomieu

Nocomis leptocephalus

Nocomis platyrhynchus

Nocomis $s p$

Notropis telescopus

Percina roanoka

$\begin{array}{ccccccccc}\text { A } & 10 & - & - & - & - & - & - & - \\ \mathrm{J} & 7 & - & - & - & - & - & - & - \\ \mathrm{A} & 276 & 346 & 36.6 & 302 & 459 & 0.37(0.05) & 0.43(0.10) & 0.43(0.10) \\ \mathrm{J} & 87 * & - & - & - & - & - & - & - \\ \mathrm{A} & 6 & - & - & - & - & - & - & - \\ \mathrm{J} & 19 & - & - & - & - & - & - & - \\ \mathrm{A} & 29 & - & - & - & - & - & - & - \\ \mathrm{J} & 19 & - & - & - & - & - & - & - \\ \mathrm{A} & 1 & - & - & - & - & - & - & - \\ \mathrm{A} & 38 & - & - & - & - & - & - & - \\ \mathrm{J} & 4 & - & - & - & - & - & - & - \\ \mathrm{A} & 25 & - & - & - & - & - & - & - \\ \mathrm{J} & 1 & - & - & - & - & - & - & - \\ \mathrm{A} & 1 & - & - & - & - & - & - & - \\ \mathrm{J} & 2 & - & - & - & - & - & - & - \\ \mathrm{A} & 73 & 80 & 8.2 & 74 & 116 & 0.56(0.08) & 0.54(0.18) & 0.54(0.18) \\ \mathrm{J} & 53 & 54 & 8.2 & 53 & 67 & 0.54(0.07) & 0.74(0.13) & 0.74(0.13) \\ \mathrm{A} & 5 & - & - & - & - & - & - & - \\ \mathrm{J} & 8 & - & - & - & - & - & - & - \\ \mathrm{A} & 29 & - & - & - & - & - & - & - \\ \mathrm{A} & 22 & - & - & - & - & - & - & - \\ \mathrm{J} & 43 & 43 & 0.0 & 43 & 43 & 0.74(0.07) & 0.85(0.10) & 0.85(0.10) \\ \mathrm{A} & 260 & 329 & 43.8 & 282 & 477 & 0.44(0.06) & 0.39(0.12) & 0.39(0.12) \\ \mathrm{A} & 1 & - & - & - & - & - & - & - \\ & & & & & & & & -\end{array}$

